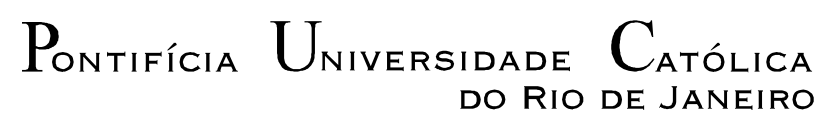

DO RIO DE JANEIRO

Fernanda Silva de Oliveira

O DITO E O NÃO DITO NO ENSINO DE PL2E: OS ATOS DE PEDIR EM PLACAS E CARTAZES NÃO OFICIAIS

Dissertação de Mestrado

Dissertação apresentada como requisito parcial para obtenção do grau de Mestre pelo Programa de PósGraudação em Estudos da Linguagem do Departamento de Letras da PUC-Rio

Orientadora: Profa. Rosa Marina de Brito Meyer

Coorientadora: Profa. Adriana Ferreira de Sousa de Albuquerque 


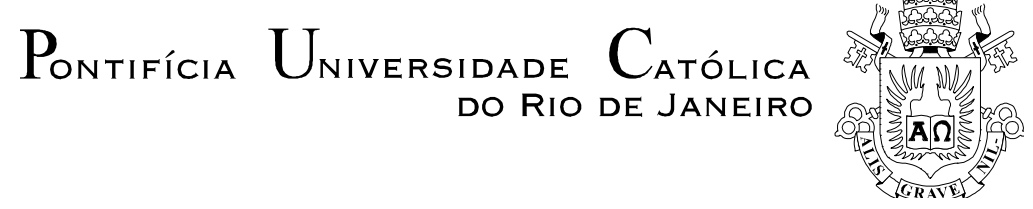

Fernanda Silva de Oliveira

\title{
O DITO E O NÃO DITO NO ENSINO DE PL2E: OS ATOS DE PEDIR EM PLACAS E CARTAZES NÃO OFICIAIS
}

\begin{abstract}
Dissertação apresentada como requisito parcial para obtenção do grau de Mestre pelo Programa de Pós-graduação em Estudos da Linguagem da PUC-Rio. Aprovada pela Comissão Examinadora abaixo.
\end{abstract}

Profa. Rosa Marina de Brito Meyer
Orientadora
Departamento de Letras - PUC-Rio

Profa. Adriana Ferreira de Sousa de Albuquerque

Coorientadora

Departamento de Letras - PUC-Rio

Profa. Vera Maria Marsicano Damazio Departamento de Artes e Design - PUC-Rio

Prof. Alexandre do Amaral Ribeiro UERJ

Rio de Janeiro, 26 de agosto de 2019. 
Todos os direitos reservados. É proibida a reprodução total ou parcial do trabalho sem autorização da universidade, da autora e da orientadora.

\section{Fernanda Silva de Oliveira}

Graduou-se em Português-Literaturas, Bacharelado e Licenciatura pela UFRJ (Universidade Federal do Rio de Janeiro) em 2014. Em 2015, concluiu o curso de Especialização "Lato Sensu" em Formação de Professores de Português para Estrangeiros na PUC-Rio (Pontifícia Universidade Católica do Rio de Janeiro). Em 2017, ingressou no Mestrado em Estudos da Linguagem na PUC-Rio. Atualmente é Professora da Secretaria Municipal de Educação do Rio de Janeiro (SMERJ).

Ficha Catalográfica

Oliveira, Fernanda Silva de

O dito e o não dito no ensino de PL2E : os atos de pedir em placas e cartazes não oficiais / Fernanda Silva de Oliveira ; orientadora: Rosa Marina de Brito Meyer ; co-orientadora: Adriana Ferreira de Sousa de Albuquerque. - 2019.

133 f. : il. color. ; $30 \mathrm{~cm}$

Dissertação (mestrado)-Pontifícia Universidade Católica do Rio de Janeiro, Departamento de Letras, 2019.

Inclui bibliografia

1. Letras - Teses. 2. Português como segunda língua para estrangeiros - PL2E. 3. Língua e cultura. 4. Estratégias linguísticas. 5. Atos de fala pedidos. 6. Placas e cartazes. I. Meyer, Rosa Marina de Brito. II. Albuquerque, Adriana Ferreira de Sousa de. III. Pontifícia Universidade Católica do Rio de Janeiro. Departamento de Letras. IV. Título. 
A minha mãe Eliete que sempre me apoiou e incentivou, além de nunca me deixar desistir dos meus sonhos 


\section{Agradecimentos}

Primeiramente, a Deus, por estar comigo em todos os momentos.

A minha família, por mostrar interesse na evolução deste projeto e por sempre acreditar em mim.

À professora Doutora Rosa Marina de Brito Meyer, pela dedicação, estímulo e pelo imenso carinho durante o caminho percorrido até aqui.

À professora e orientadora Adriana F. de Sousa de Albuquerque pelo incentivo, confiança e pela orientação sempre atenta. Obrigada, principalmente, por considerar minhas ideias.

Às minhas colegas e amigas de mestrado, Adriana Borgerth, Luciana Kreutzfeld e Manjulata Sharma, que viveram comigo este percurso com a mesma intensidade. Com quem foram partilhadas ideias, conquistas, medos e derrotas. Foram, sem dúvida, grandes companheiras.

Aos demais amigos pelo interesse demonstrado desde a minha entrada no mestrado, pela preocupação, pela força, pelas mensagens e também pelos momentos que não pude partilhar com eles devido à minha falta de tempo, mas que mesmo assim compreenderam e permaneceram comigo.

À Capes e à PUC-Rio, pelos auxílios concedidos, sem os quais este trabalho não poderia ter sido realizado.

À equipe do Departamento de Letras da PUC-Rio, especialmente à Chiquinha, pela ajuda e atenção durante todo o curso.

Aos professores que participaram da Comissão Examinadora.

O presente trabalho foi realizado com apoio da Coordenação de Aperfeiçoamento de Pessoal de Nível Superior - Brasil (CAPES) - Código de Financiamento 001.

Sem todos vocês não teria conseguido chegar até aqui. $\mathrm{O}$ meu mais sincero obrigada a todos. 


\section{Resumo}

Oliveira, Fernanda Silva de; Meyer, Rosa Marina de Brito; Albuquerque, Adriana Ferreira de Sousa. O dito e o não dito no ensino de PL2E: os atos de pedir em placas e cartazes não oficiais. Rio de Janeiro, 2019. 133p. Dissertação de Mestrado - Departamento de Letras, Pontifícia Universidade Católica do Rio de Janeiro.

O tema desta pesquisa é a realização dos atos de pedir, registrados em placas e cartazes não oficiais, localizados em espaços de circulação pública da sociedade brasileira. A partir de uma perspectiva interdisciplinar, este estudo pretende contribuir para uma melhor compreensão das questões identitárias e culturais trazidas na e pela língua, fornecendo subsídios relevantes para a área de ensino de português como segunda língua para estrangeiros (PL2E). Apesar de placas e cartazes objetivarem manter a informação necessária clara para o seu leitor e ativa na memória, nem sempre o principal conteúdo transmitido está explícito no enunciado, sendo construído, muitas vezes, por meio de uma informação subentendida. Para os aprendizes de PL2E, compreender essa mensagem não dita, sobretudo nos enunciados expressos pelos avisos de placas e cartazes não oficiais, requer não só um grande desafio, como também pode gerar interpretações equivocadas e visões distorcidas da cultura alvo. Tendo isso em vista, as formas de realização das estratégias discursivas relativas ao ato de pedir são descritas e analisadas, procurando-se verificar em que medida os fatores contextuais e culturais influenciam na escolha das estratégias linguísticas utilizadas para elaborar atos de pedir explícitos ou implícitos. Para tal, a fundamentação teórica desta dissertação baseia-se nos conceitos da Teoria dos Atos de Fala, da Sociolinguística Interacional, do Interculturalismo e da Antropologia Social.

\section{Palavras-chave}

Português como Segunda Língua para Estrangeiros - PL2E; Língua e cultura; Estratégias linguísticas; Atos de fala Pedidos; Placas e cartazes. 


\section{Abstract}

Oliveira, Fernanda Silva de; Meyer, Rosa Marina de Brito (Advisor); Albuquerque, Adriana Ferreira de Sousa. The said and the unsaid in PL2E teaching: the act of requesting on unofficial signs and posters. Rio de Janeiro, 2019. 133p. Dissertação de Mestrado - Departamento de Letras, Pontifícia Universidade Católica do Rio de Janeiro.

The theme of this research is the execution of the acts of asking, registered in unofficial signs and posters, located in public circulation spaces of the Brazilian society. From an interdisciplinary perspective, this study aims to contribute to a better understanding of the identity and cultural issues brought in and by the language, providing relevant subsidies for the teaching of Portuguese as a Second Language for Foreigners (PL2E). Although signs and posters aim to keep the necessary information clear to the reader and active in memory, not always the main content conveyed is explicit in the utterance and is often constructed by means of implied information. For learners of PL2E, understanding this unsaid message, especially in statements expressed by unofficial placard and poster warnings, requires not only a major challenge, but can also generate misinterpretations and distorted views of the target culture. With this in mind, the ways in which discursive strategies regarding the act of asking are realized are described and analyzed, trying to verify to what extent the contextual and cultural factors influence the choice of the linguistic strategies used to elaborate explicit or implicit acts of asking. To this end, the theoretical foundation of this dissertation is based on the concepts of Speech Acts Theory, Interactional Sociolinguistics, Interculturalism and Social Anthropology.

\section{Keywords}

Portuguese as a Second Language for Foreigners - PL2E; Language and culture; Language strategies; Speech Acts; Requests; Signs and posters. 


\section{Sumário}

1. Introdução 13

1.1 Justificativa e relevância do trabalho 15

$\begin{array}{ll}1.2 \text { Objetivos gerais e específicos } & 16\end{array}$

2. Revisão de Literatura 18

2.10 Gênero Textual Aviso 18

2.2 Placas e cartazes: gênero e suporte 20

2.2.1 Placas e cartazes: oficiais e não oficiais 27

2.3 Espaço público e espaço privado $\quad 27$

$2.4 O$ tratamento dado às noções de pedido nas gramáticas 29 tradicionais de PLM

3 Pressupostos teóricos 34

3.1 A Teoria dos Atos de Fala 35

3.1.1 Caracterização de pedidos como Ato de Fala 39

3.1.1.1 Definindo as unidades de análise $\quad 41$

3.1.1.2 Tipos de Estratégia 44

3.1.1.3 Atenuantes gramaticais e lexicais $\quad 46$

3.2 Conceitos da Sociolinguística Interacional $\quad 47$

3.2.1 Face 48

3.2.2 Polidez $\quad 50$

3.2.3 Impolidez 54

$3.3 \mathrm{O}$ Interculturalismo $\quad 55$

3.3.1 Língua e Cultura: um encontro possível 56

3.3.2 Cultura de alto contexto e de baixo contexto 58

3.3.3 Dimensões culturais $\quad 59$

3.4 Conceitos da Antropologia Social 62

3.4.1 A casa e a rua $\quad 62$

3.4.2 Indivíduo e pessoa $\quad 64$

4 Aspectos Metodológicos $\quad 67$

$\begin{array}{ll}\text { 4.1 Natureza da pesquisa } & 67\end{array}$ 
4.2 Natureza dos dados

4.3 Organização do corpus e procedimentos de análise

5 Análise dos Dados

5.1 Ameaça

5.2 Agressividade

80

5.3 Apelo

87

5.4 Cordialidade

93

5.5 Disciplina

100

5.6 Ironia

104

6 Outros atenuantes lexicais e gramaticais

6.1 Estrutura do ato ilocucionário dos atos de pedir em placas e cartazes não oficiais

6.1.1 A partir do ato principal exclusivamente

6.1.2 A partir de título + ato principal

6.1.3 A partir de marcadores de polidez cristalizados + ato principal

6.1.4 A partir de cumprimento e/ou chamamento, e/ ou saudações + ato principal

6.1.5 Sentenças interrogativas

6.1.6 Ato(s) principal(is) + justificativa

6.2 Estratégias que atenuam o teor de imposição dos atos diretivos

6.2.1 Estratégias que atenuam o teor da imposição

6.2.2 Estratégias que reforçam a imposição

7 Considerações finais 


\section{Lista de Quadros e Figuras}

\section{Quadros}

Quadro 1 - Relação entre tipo de propriedade privada e tipo de usos do 28 espaço das cidades

Quadro 2 - Tipos de estratégias de pedidos

Quadro 3 - Estratégias de polidez propostas por Brown e Levinson (1987) 52

Quadro 4 - Descrição das dimensões da cultura nacional 60

Quadro 5 - Noções de indivíduo e pessoa 65

\section{Figuras}

Figura 1 - Placa de identificação - Sanitários $\quad 21$

Figura 2 - Placa direcional - Parque Florestal Municipal Eurico Figueiredo - 22 Conselheiro Lafaiete/MG

Figura 3 - Placa descritiva - Gramado Zoo 22

Figura 4 - Placa Normativa - Parque Ecológico Córrego Grande - Florianópolis 23 $-\mathrm{SC}$

Figura 5 - Placa de orientação - Mapa turístico - RJ 23

Figura 6 - Cartaz do Ministério da Saúde em campanha de contra a dengue $\quad 24$

Figura 7 - Cartaz Guaraná Antarctica $\quad 24$ 


\section{Siglas}

CCSARP - Cross-Cultural Speech Act Realization Patterns

FTA - Face threatening act (Ato ameaçador da face)

PL2E - Português como segunda língua para estrangeiros

PLE - Português como língua estrangeira

PB - Português brasileiro

L2 - Segunda língua

LE - Língua estrangeira 
O olhar percorre as ruas como páginas escritas: a cidade diz como se deve lê-la. Como é realmente a cidade sob esse carregado invólucro de símbolos, o que conta e o que esconde, parece impossivel saber.

Nelson Brissac 


\section{Introdução}

Ensinar uma língua como o português, e, num sentido mais amplo, ensinar qualquer outra língua, é também expor um modo de ser e de viver, uma vez que ela reflete um “[...] país, cultura, local geográfico, fronteira e território reconhecidos internacionalmente, e também casa, pedaço de chão calçado com o calor de nossos corpos, lar, memória e consciência de um lugar com o qual se tem uma ligação especial, única, totalmente sagrada" (DaMatta, 1986, p.8).

Ao tomar emprestado de DaMatta este trecho em que fala do Brasil, contatamos que a língua, mais do que um instrumento de comunicação, é um símbolo, um sistema de produção de significados individuais, sociais e culturais. E, sendo assim, é nela e por ela que também as culturas podem ser lidas a fim de se tentar entender os mais variados modos de vida da população que nelas se trafegam, (re)inventam, manifestam, disputam espaço ou mesmo ditam o mundo social.

Pensando especificamente no contexto brasileiro é preciso considerar que parte dessa compreensão envolve elementos disponíveis no próprio espaço urbano - seja o jeito de usar um acessório, o gosto por determinado tipo de música, o uso de um falar específico, o planejamento do que fazer nos dias de folga, etc. Tais hábitos refletem modos de vida que deixam rastros pela cidade. São práticas que se produzem socialmente, se transformam e, inclusive, se comunicam.

Desse modo, inevitavelmente se revelam por meio da língua e afirmam que a "brasilidade é um estilo, uma maneira particular de perceber e construir a realidade". (DaMatta, 1986, p.6). É o caso do presente estudo, que tem por tema a realização dos atos de pedir realizados em avisos que contemplam, especificamente, placas e cartazes de orientação não oficiais, localizados em espaços de circulação pública e privada da sociedade brasileira.

Ao circular pelas cidades do Brasil, é nítido perceber que o uso de placas e cartazes para transmitir diferentes avisos nesses espaços é comum. Isso porque tal gênero transmite a informação necessária de forma breve e em linguagem concisa a seu leitor. No entanto, o principal conteúdo proposicional presente nesses suportes nem sempre está perceptível no enunciado, sendo eles construídos, muitas vezes, por intermédio de uma informação subentendida. 
Para falantes nativos de português brasileiro (doravante PB), por possuírem conhecimentos que compõem a memória social da cultura em que estão imersos, há uma compreensão inconsciente da forma como se estruturam os enunciados da língua e o que pretendem. Por outro lado, para um falante nãonativo, o processo de compreensão não acontece da mesma maneira e se torna ainda mais difícil ao estar em um país estranho e em um ambiente linguístico totalmente distinto da sua realidade. Principalmente, se considerarmos o estrangeiro imerso em uma cultura em que a essência da declaração está na mensagem verbal, direta e explícita. Ao contrário da nossa, em que grande parte das informações não é transmitida verbalmente, sendo inferida pelo contexto sociocultural.

Portanto, todo o percurso investigativo tem como objetivo identificar, descrever e analisar as formas de realização das estratégias discursivas relativas aos atos de pedir em avisos veiculados em placas e cartazes, em sua dimensão escrita, bem como interpretar os motivos que condicionam os falantes nativos a fazerem a escolha das referidas formulações, em diferentes níveis de diretividade.

Assim, este trabalho visa a oferecer suporte teórico e prático para professores de português como segunda língua $\left(\mathrm{PL}^{2} \mathrm{E}^{1}\right)$ e língua estrangeira (PLE), e demais interessados na área, no que diz respeito ao ensino dos atos de fala, especificamente de pedidos, a fim de que, a partir de estudos mais aprofundados, sejam estabelecidas práticas pedagógicas que possam dar conta do ensino dessas estruturas com ênfase na cultura subjetiva ${ }^{2}$ para os estrangeiros que aprendem o português brasileiro, principalmente, em contexto de imersão.

Com relação às terminologias aqui mencionadas, é importante esclarecer que existe, na literatura sobre o ensino de línguas, frequente divergência entre a conceituação de segunda língua e língua estrangeira. Assim, reconhecemos as diferenças nos contextos para o uso do termo L2 (segunda língua ou língua segunda) e LE (língua estrangeira), como fazem os autores Leffa (1988), Leiria

\footnotetext{
${ }^{1}$ Terminologia e sigla cunhadas pela professora Rosa Marina de Brito Meyer (PUC-RJ), utilizadas para descrever o objeto das pesquisas desenvolvidas no Percurso de Formação "Português como segunda língua para Estrangeiros: descrição e ensino" do programa de pós-graduação em Estudos da Linguagem do Departamento de Letras da Pontifícia Universidade Católica do Rio de Janeiro (PUC-Rio).

${ }^{2}$ Segundo Bennett (1998), a cultura subjetiva refere-se a um conjunto de crenças, hábitos e valores culturais que estabelece os diferentes modos de interação de uma determinada sociedade, diferentemente da cultura objetiva, que consiste em manifestações visíveis de uma determinada sociedade, incluindo os sistemas social, econômico, político e linguístico.
} 
(2004), Spinassé (2006), que diferenciam esses termos considerando a L2 como uma língua desenvolvida em um espaço que favoreça um contato mais intenso com essa língua, e a LE como uma língua desenvolvida em ambientes fisicamente distantes de onde esse idioma é falado e que, diferentemente da L2, necessita de recursos didáticos para desenvolver a aprendizagem da língua alvo. Além do mais, associado a tais siglas, o ensino de português para estrangeiros recebe variadas denominações. Optamos, dessa forma, por utilizar neste trabalho o termo PL2E - sigla utilizada pela instituição a que estou vinculada e que contempla a aprendizagem do português em contexto de imersão.

Quanto à organização do trabalho, este se divide em sete seções principais. O primeiro capítulo, no qual nos encontramos, é a seção em que se expõe a introdução do trabalho. $\mathrm{O}$ segundo capítulo tem a finalidade de apresentar a Revisão de Literatura, que tratará dos estudos relacionados ao tema. O terceiro capítulo, Pressupostos Teóricos, apresentará os conceitos instrumentais de análise, com os quais interpretamos as formulações dos atos de pedir e as estratégias discursivas utilizadas, que reforçam ou atenuam a imposição desses atos. São utilizados os conceitos desenvolvidos pela Teoria dos Atos de Fala, pela Sociolinguística Interacional, pelo Interculturalismo e pela Antropologia Social. No quarto capítulo, apresenta-se a Metodologia utilizada nesta pesquisa para a coleta de dados, buscando mostrar como o trabalho será realizado. O quinto e o sexto capítulo consistem em analisar os dados, observando a estrutura dos pedidos, bem como os aspectos culturais que influenciam nas escolhas lexicais feitas pelos falantes. No sétimo e último capítulos apresentam-se as Considerações Finais deste trabalho em que demonstraremos a relevância deste trabalho para uma prática pedagógica mais eficaz. Em anexo, estão as fontes das imagens de placas e cartazes selecionados.

\section{1}

\section{Justificativa e relevância do trabalho}

Devido às particularidades mencionadas anteriormente, percebemos que compreender ou fazer um pedido pode não ser uma tarefa tão simples de ser acatada ou realizada. Sendo assim, como possibilitar que um aprendiz estrangeiro, desprovido de intuição linguística na cultura brasileira, seja capaz de compreendê- 
lo ou fazê-lo adequadamente, consciente das sutilezas que o processo envolve e, principalmente, das diferenças interacionais entre a cultura alvo e a sua própria cultura? De que estratégias linguístico-discursivas se valem os falantes nativos para atenuar o impacto de certas formulações de pedido do português brasileiro? Ter uma conduta polida nesses casos requer necessariamente o uso de construções mais indiretivas?

Tais questionamentos apontam para existência de um número considerável de fatores que influenciam a construção de pedidos em interações orais e escritas. São fatores como distância social, poder, cumplicidade, intimidade e envolvimento, que atuam significativamente nas escolhas linguísticas feitas pelos falantes, pois são esses os parâmetros que guiam o discurso, e não elementos puramente formais da língua.

Tendo isso em vista, escolhemos pesquisar os atos de fala de pedidos em placas e cartazes não oficiais devido ao fato de oferecerem um campo particularmente fecundo para o estudo das conexões entre a polidez linguística, os aspectos culturais e as variáveis sociais, como o grau de proximidade entre os interlocutores e os tipos de relações estabelecidas entre eles. As variedades das formulações possíveis para os atos de pedir e a abundância de avisos espalhados por diversos ambientes, como elementos de comunicação popular no espaço urbano brasileiro, fazem com que esta seja uma área de investigação necessária para o ensino de PL2E.

Além disso, como os avisos em placas e cartazes não oficiais podem ser espelhos de uma sociedade, refletindo seus traços culturais mais expressivos, e como a cultura é parte indissociável do aprendizado de línguas estrangeiras, o estudo apresentou-se instigante e bastante motivador, e consideramos que seus resultados poderão ser, sem dúvida, de grande importância para outras pesquisas que venham a ser desenvolvidas nessa ou em outras áreas de estudos.

\section{2}

\section{Objetivos}

O anonimato crescente das relações sociais na cidade não abre mão de momentos e situações de contato com o outro. Ao circular pelas cidades, podemos constatar que estamos cada vez mais cercados de sinalizações e marcas materiais 
da convivência no espaço urbano. E, com isso, é cada vez mais comum encontrarmos um diverso e rico conjunto de mecanismos e estratégias que expressam atos de solicitações em formas de placas e cartazes.

Para nós, brasileiros, a presença disseminada de informes/dizeres/avisos pela cidade pode passar apenas por inscrições criativas ou gracejos que resultam em observações como "o melhor do Brasil é o brasileiro"3. Porém, para falantes de outras línguas, tais avisos podem surtir efeitos contrários, resultando em uma compreensão equivocada da cultura em questão e, por consequência, da língua, gerando choques culturais.

Tendo em vista o que expusemos até aqui, nosso objetivo geral se propõe a identificar, descrever e analisar as estratégias envolvidas nos modos de expressão dos atos de pedidos em avisos que contemplam, especificamente, placas e cartazes não oficiais, em diferentes contextos situacionais. A partir dessa proposta, formulamos os seguintes objetivos específicos:

1. Identificar e descrever as escolhas linguísticas e não linguísticas na produção do ato de fala pedido, enunciado em placas e cartazes não oficiais;

2. Fazer o levantamento das variadas estratégias discursivas utilizadas pelo falante nativo para expressar direta ou indiretamente a sua intenção de pedir por meio de placas e cartazes.

3. Analisar e confrontar os atos de pedido realizados de forma direta e indireta, tomando por base o contexto de produção dos enunciados;

4. Identificar até que ponto fatores contextuais e culturais, além de fatores como distanciamento/proximidade e formalidade/informalidade interferem nas escolhas discursivas e na forma como os brasileiros realizam pedidos em uma conversação;

5. Observar a cortesia como fenômeno de harmonização das interações verbais e manutenção da imagem dos interlocutores;

6. Destacar as contribuições deste estudo para o ensino-aprendizagem de PL2E.

\footnotetext{
${ }^{3}$ Slogan da campanha criada pela ABA (Associação Brasileira de Anunciantes) para resgatar a autoestima dos brasileiros. Disponível em: <http://propmark.com.br/anunciantes/o-melhor-dobrasil-e-o-brasileiro>. Acesso em: 15 fev.19.
} 


\section{Revisão de Literatura}

Para embasar este trabalho, mostrou-se necessário recorrer a conceitos e autores cujas obras e pesquisas são consideradas referência nas áreas de conhecimento que permeiam o estudo desenvolvido.

No que tange aos trabalhos a respeito da constituição do gênero, em especial, do gênero do discurso aviso, lançou-se mão de autores como Marcuschi (2008), Costa (2009), Mendes e Júnior (2018) e os estudos realizados por Andrade (2015).

Já em relação a placas e cartazes, classificados na literatura especializada tanto como gênero e suporte textuais, recorreu-se aos trabalhos de Marcuschi (2003), Bakhtin (2003) e Costa (2008), para o estabelecimento de tal diferenciação, e, além disso, buscou-se por estudos que enfatizassem a constituição e funcionalidade desses materiais nos diferentes espaços sociais e coletivos, como os de Mollerup (2005), Smitshuijzen (2007), Almeida (2010) e Gusso, Santos e Silva (2013), os quais forneceram informações importantes sobre $\mathrm{o}$ assunto.

Para a compreensão das situações sociais específicas onde se inserem os suportes textuais deste trabalho, consideramos também conveniente estabelecer a diferenciação entre espaço público e espaço privado, e por isso dialogamos com estudos como os de Oliveira (2013), Grolle (2008), situados no âmbito da Arquitetura e Urbanismo (Oliveira, 2013).

Por último, nesta seção, abordaremos o tratamento dado às noções de pedido nas gramáticas tradicionais de português língua materna nas obras de Cunha e Cintra (2008), Bechara (2009) e Lima (2010).

\section{1}

\section{O Gênero Textual Aviso}

Segundo Marcuschi (2008, p. 163), apesar de designarmos frequentemente os gêneros que produzimos em nossas práticas sociais, devido a uma riquíssima metalinguagem que é intuitivamente utilizada, a tarefa de "[...] 
determinar os nomes de cada gênero de texto" se mostra ainda como um tarefa difícil. Os gêneros continuamente se "[...] imbricam e interpenetram para constituírem novos gêneros", inexistindo assim, uma característica uniforme em relação às formas textuais. Portanto, um gênero textual pode ter a função de outro, como é típico das publicidades, assim como um mesmo gênero pode estar presente em outro, como é o caso do gênero aviso, que muitas vezes pode estar presente em diversos tipos distintos de sinalização, como, por exemplo, sinalização predial ou de trânsito; ou ainda ser um texto em formato de carta, cartaz, bilhete, recado, etc. com diferentes funções, podendo tratar-se de um sinal, um conselho ou uma chamada de atenção.

Devido à expressiva variedade de avisos, constata-se que este tipo de estratégia linguística constitui um gênero com subgêneros. Isso se deve, principalmente, aos aspectos estruturais e interacionais desses textos, que não apresentam os mesmos elementos em sua composição. $\mathrm{O}$ aviso possui uma grande variedade de formas, alguns com dados, logotipo, uns mais longos outros curtos, cada um, dependendo da finalidade, do remetente e do destinatário, é nomeado diferentemente. Assim, por ser um gênero que admite variedades, apresenta-se por diversos nomes: aviso de pauta; aviso de infração; aviso de recebimento; aviso de cobrança; aviso de infração, dentre muitos outros. Por isso, é necessário categorizá-los, observando semelhanças e diferenças existentes entre eles, facilitando suas produções e interpretações.

De modo geral, pode-se dizer que o gênero textual aviso é muito utilizado com o propósito de dar uma informação com eficiência ao público a quem se dirige, de forma breve, com uma linguagem concisa e clara. Segundo Costa (2009), em seu Dicionário de Gêneros textuais, por meio desse tipo de produção, o usuário da língua procura comunicar, informar, noticiar, levar o conhecimento de algo ou alguém aos membros da sociedade por onde se circula.

Quanto à sua estrutura, como já mencionado, o aviso poderá se apresentar de diversas formas. Mas, de acordo com Andrade (2015, p.70), o mesmo se apresenta, em geral, da seguinte forma: o elemento identificador do gênero (o termo Aviso); o destinatário; o corpo do texto (assunto); e, por fim, é possível que se encerre com uma fórmula de despedida e assinatura, não sendo comum o uso do título. A autora ainda acrescenta que Mendes e Júnior (2018, p. 26-27), autores do Manual de Redação da Presidência da República, pontuam que, na 
elaboração de avisos oficiais, há o acréscimo do vocativo (pronomes de tratamento), seguido do nome e cargo do destinatário. Constam nele também o número do aviso, local e data. A assinatura é seguida pelo cargo do signatário.

Essa configuração demonstra que as formas de organização social têm um papel importante nas práticas discursivas, uma vez que implicam a seleção e arranjo dos elementos linguísticos que compõem o gênero. Esse aspecto centra-se no fato de que os sujeitos que atuam em determinado domínio discursivo sentem a necessidade de fazer adaptações e/ou reorientações de determinado gênero, a fim de atender às suas necessidades específicas. Portanto, o aviso poderá se apresentar de diferentes maneiras, ora mais formais, ora mais informais, pois as condições de produção do gênero estão essencialmente relacionadas às diferentes situações de enunciação em diversas esferas da vida social. Um aviso, por exemplo, que circula em estabelecimentos comerciais, possivelmente, apresenta aspectos diferentes dos avisos que circulam nas universidades.

Considerando, portanto, o aviso como um produto cultural, social e histórico, existente nas práticas sociais, nota-se uma grande variedade quanto à forma de realização de acordo com o uso e a função que deste são feitos, função primeira de comunicar algo a alguém, conservando os elementos estruturais remetente/destinatário - comum a outros avisos, que recebem diversos substantivos agrupados ao nome do gênero (que os fazem ser nomeados diferentemente) os quais designam a finalidade do texto escrito. Logo, acreditamos que o gênero aviso, independente do meio pelo qual é enviado (correio, fax ou e-mail), faz parte de uma constelação que agrupa diversos textos.

\section{2}

\section{Placas e cartazes: gênero e suporte}

As placas e cartazes estão presentes em toda a sociedade e têm comumente por objetivo organizar, apontar, advertir ou regulamentar ações por meio de informações importantes para determinado fim. É relevante ressaltar que tais termos podem reportar-se tanto ao gênero, isto é, àqueles textos que encontramos em nossa vida diária e que apresentam as informações organizadas de determinada forma e cumprem definidos objetivos - quanto ao suporte de gêneros, isto é, o meio pelos quais os variados gêneros são veiculados. Essa diferenciação se faz 
necessária, pois nem todas as placas e cartazes apresentam os mesmos propósitos de comunicação, os mesmos interlocutores, nem o mesmo contexto situacional.

Assim, no que se refere às placas e cartazes como gêneros textuais, podese defini-los da seguinte forma: as placas seriam um gênero cujo objetivo é chamar a atenção para indicações ou informações importantes na utilização de vias, de lugares, produtos, serviços, etc. Para que sua mensagem seja percebida e não deixe dúvidas, são usados símbolos, cores e palavras em destaque. Além disso, os textos linguísticos apresentados são de menor extensão e objetivos. De acordo com Mollerup (2005, apud Almeida, p.32), as placas podem ser classificadas de acordo com a função a que se destinam:

a. Identificadora: demonstra identidade, distinguindo um local, destacando o que há nele e o que é, e também define posição ou um elemento localizado em determinado local. (Figura 1).

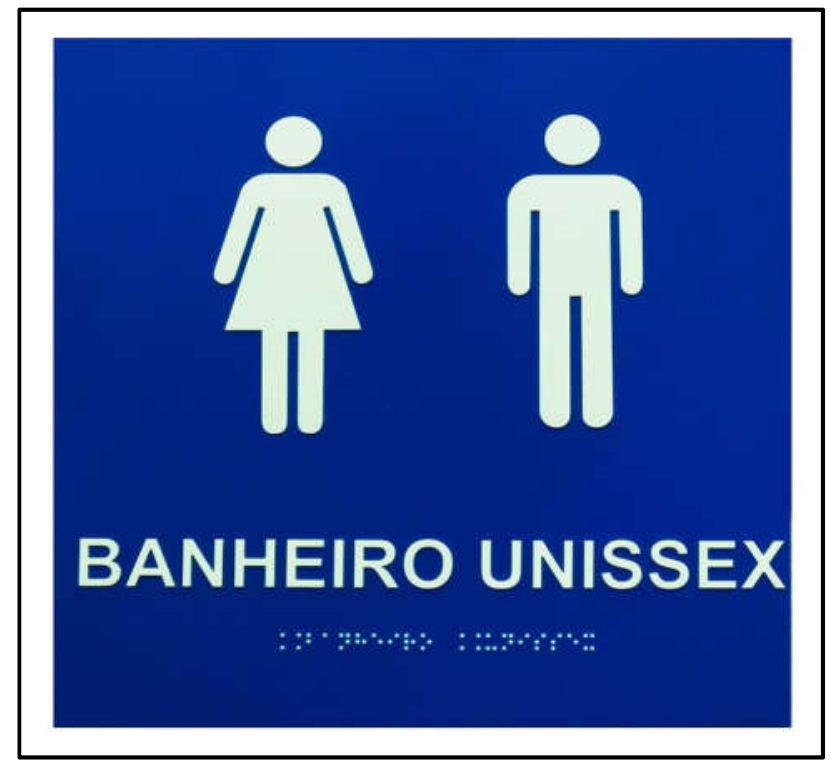

Figura 1: placa de identificação - Sanitários.

b. Direcional: indica um percurso ou direção, de uma origem para um destino desejado, geralmente definida por uma seta acompanhada de informação textual ou pictórica (Figura 2). 


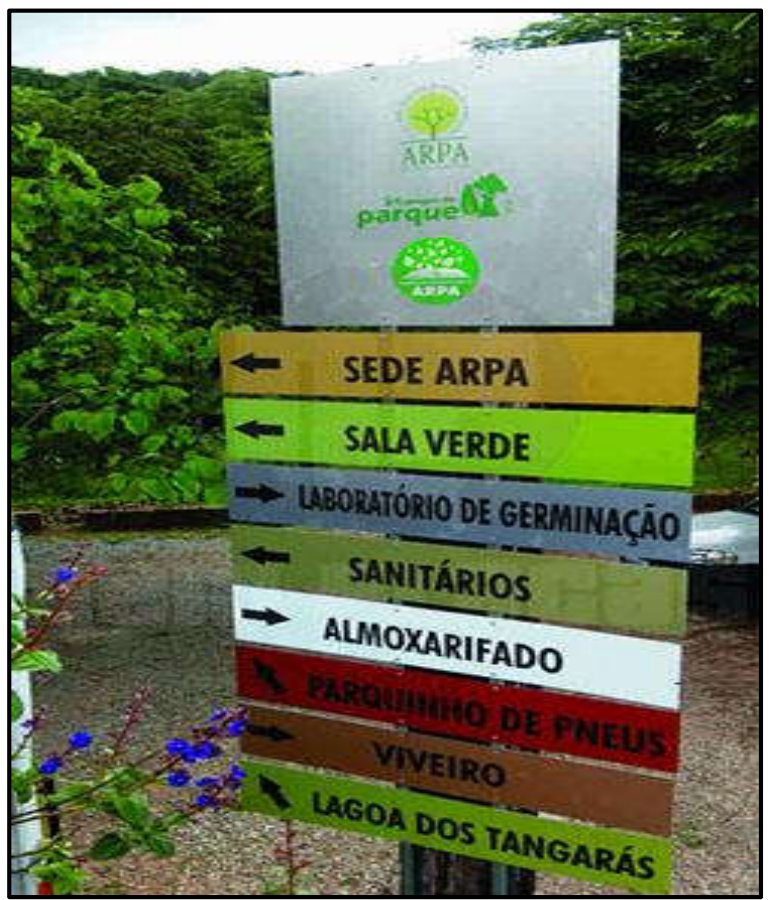

Figura 2: placa direcional - Parque Florestal Municipal Eurico Figueiredo - Conselheiro Lafaiete/MG.

c. Descritiva: apresenta a situação, normalmente utilizada para expor a condição do usuário em determinado local. Nesses casos, as placas costumam se comunicar com o observador, orientando, explicando ou instruindo (Figura 3).

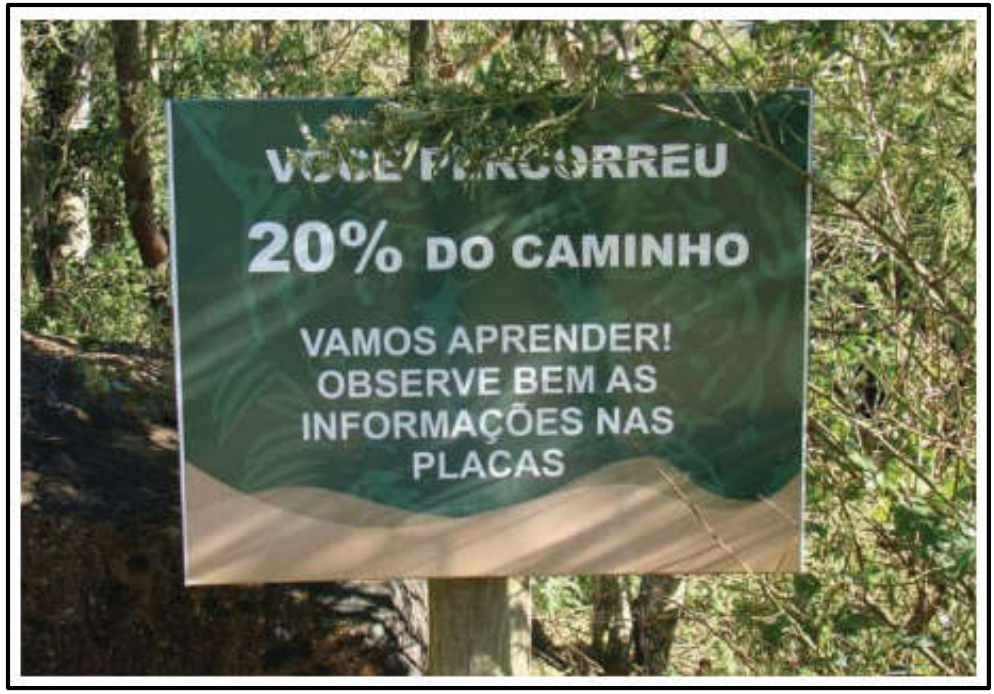

Figura 3: placa descritiva - Gramado do Jardim Zoológico. 
d. Normativa: também conhecida como sinalização de comando, alerta ou proibição. Regulamenta o uso de determinada área considerando a segurança e a utilização do ambiente (Figura 4).

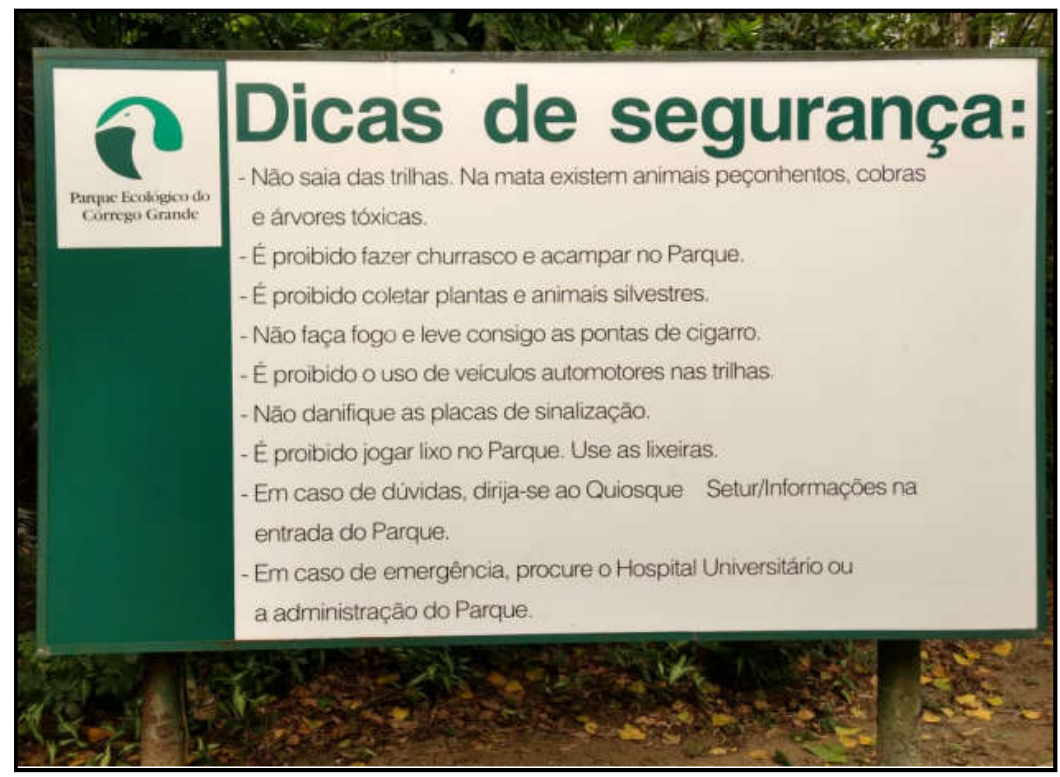

Figura 4: placa normativa - Parque Ecológico Córrego Grande - Florianópolis - SC.

e. Orientadora: esta placa é estruturada por elementos que auxiliam o usuário na formação de um mapa cognitivo. Esta sinalização compreende principalmente a exposição do espaço físico por meio de mapas ou gráficos, auxiliando a orientação espacial (Figura 5).

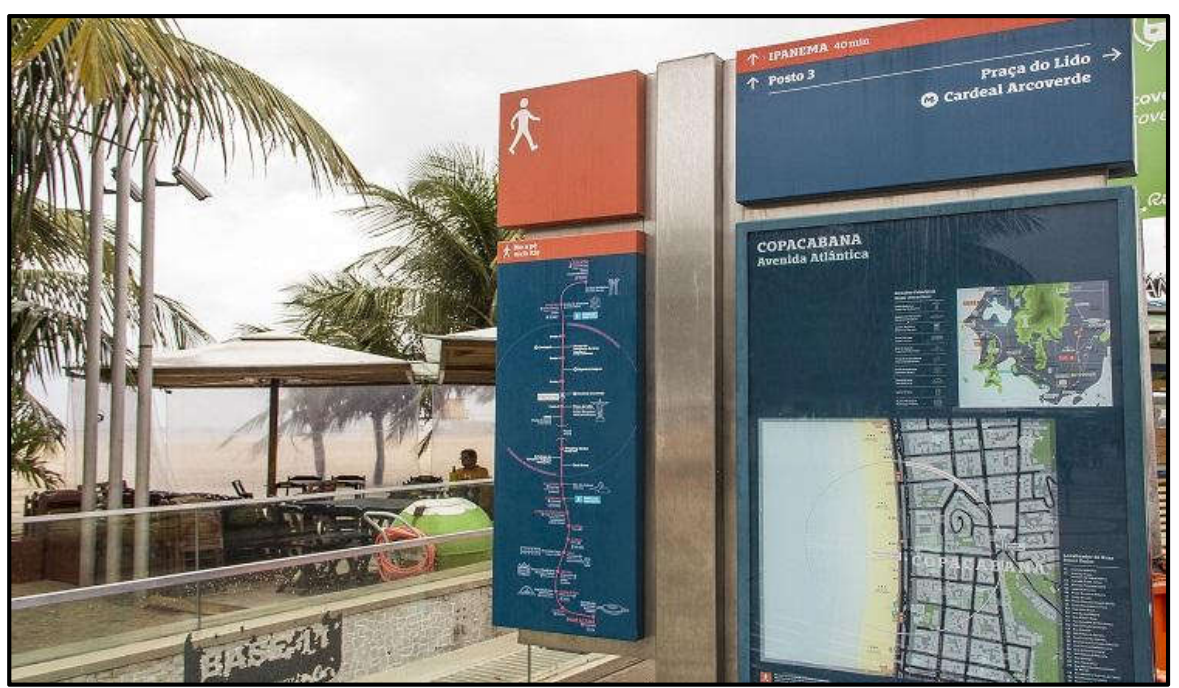

Figura 5: placa de orientação - Mapa turístico - RJ 
O cartaz, por sua vez, segundo Gusso, Santos e Silva (2013), tem a função de expor algo, a fim de avisar e/ou persuadir seu interlocutor através de apelos visuais e verbais que pretendem sensibilizá-lo ou convencê-lo daquilo que está sendo comunicado. Normalmente, compõe-se por linguagem verbal e visual, o que o identifica como um gênero multissemiótico. Percebe-se, em alguns casos, que os cartazes apresentam textos linguísticos de maior extensão do que as placas. Essas diferenças, no entanto, não são regras e tornam-se muito sutis dependendo do texto e do contexto analisado.

O cartaz também é muito utilizado em campanhas governamentais, por ser um meio capaz de alcançar a população em geral de modo eficaz, já que sua configuração facilita sua exposição nas mais diversas repartições e espaços públicos e, além disso, pode ser multiplicado em suportes produzidos com materiais de baixo custo, oferecendo, assim, uma excelente opção de disseminação de informações. A publicidade também se utiliza desse gênero, geralmente com a intenção de persuadir, convencer o leitor, enquanto, para outros fins, ele tem uma função mais expositiva e informativa. Observem-se os exemplos apresentados nas imagens a seguir.

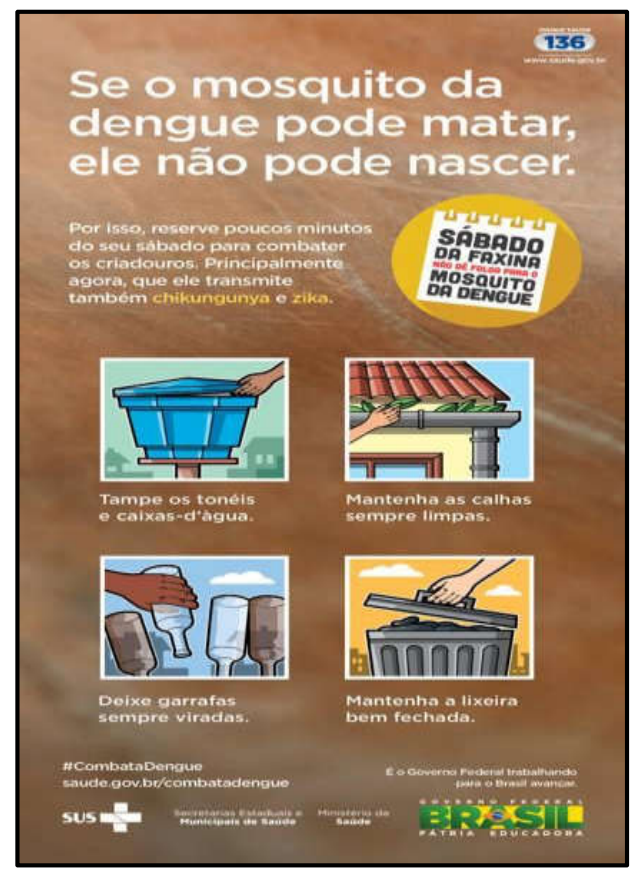

Figura 6: Cartaz do Ministério da Saúde em campanha contra a dengue. Fonte: PROEX UFRN, 2016.

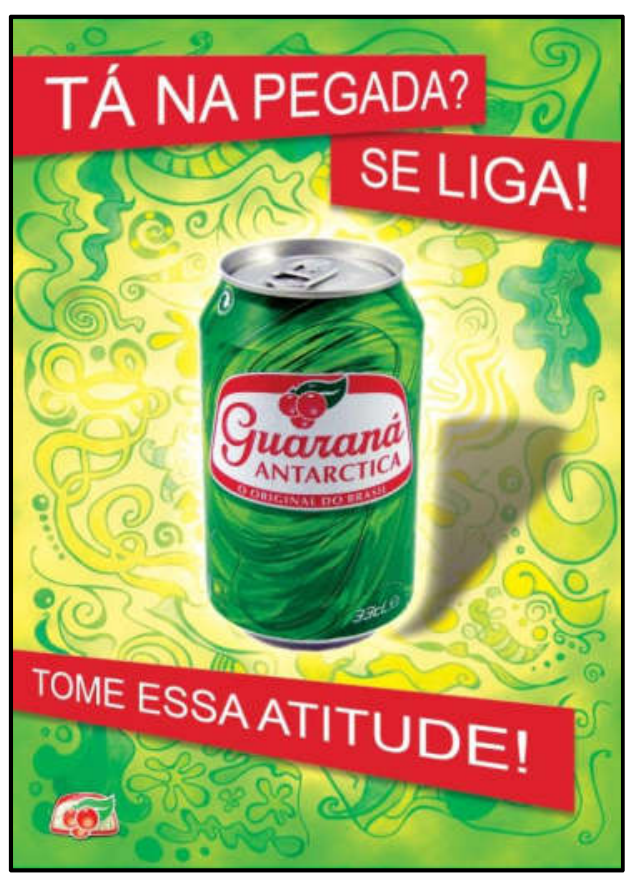

Figura 7: Agência Premione - Cartaz Guaraná Antarctica, 2011. 
Elaborado também de forma mais simples, esse gênero pode ser usado em manifestações como passeatas, protestos e acontecimentos públicos que os participantes buscam reivindicar ou se manifestar de forma breve e objetiva, mostrando-se versátil e de grande valor informativo.

Uma vez que placas e cartazes aqui também estão sendo tratados como suporte, faz-se necessário elucidar, ainda que brevemente, esse assunto e quais questões subjazem a ele. Segundo Marcuschi (2003), o suporte é um portador do texto,

mas não no sentido de um meio de transporte ou veículo, nem como um suporte estático e sim como um locus no qual o texto se fixa e que tem repercussão sobre o gênero que suporta. [...] um locus físico ou virtual com formato específico que serve de base ou ambiente de fixação do gênero materializado como textos. (p. 8).

A partir dessa definição, o autor estabelece três considerações importantes, a saber: a) o suporte é um lugar físico ou virtual; b) o suporte tem formato específico; c) o suporte serve para fixar e mostrar o texto (Marcuschi, 2003, p.10). Para além dessas três características, também deixa clara a relevância que o suporte pode ter no estabelecimento de sentidos do texto, por meio do seguinte exemplo:

Paulo, te amo, me ligue o mais rápido que puder. Te espero no fone 554433 22. Verônica.

Para Marcuschi (2003), dependendo de onde o suporte onde tal texto esteja fixado, ele poderá adquirir diversos significados. Mais do que isso, a mensagem poderá ainda ser entendida como constitutiva de gêneros textuais diferentes:

Se isto estiver escrito num papel colocado sobre a mesa da pessoa indicada (Paulo), pode ser um bilhete; se for passado pela secretária eletrônica é um recado; remetido pelos correios num formulário próprio, pode ser um telegrama; exposto num outdoor pode ser uma declaração de amor. O certo é que o conteúdo não muda, mas o gênero é sempre identificado na relação com o suporte. (Marcuschi, 2003, p.2). 
O autor, desse modo, propõe que alguns gêneros textuais dependem da fixação em suportes para circular na sociedade, bem como para serem reconhecidos como pertencentes a um determinado gênero. A partir dessa colocação, podemos também pressupor que determinados textos mantêm uma forte correspondência com seu suporte, e que, além de serem por ele influenciados, também cooperam para sua estruturação e fixação no meio social.

Posto isto, placa e cartaz são também considerados suporte por dar característica de estilo ao gênero que suportam, já que o estilo é fator determinante do gênero, segundo Bakhtin (2003). Para compor tal feito, a placa, segundo Smitshuijzen (2007 apud Almeida, 2010, p. 32), pode ser construído em diversos materiais e compor o ambiente de diversas formas (terrestres, aéreas), sem uma definição precisa de tamanhos. De modo mais específico Costa (2008, p.44) acrescenta que:

Assim como o outdoor (v.), o cartaz (v.) ou o painel (v.), a placa é um suporte, com formato de tabuleta, geralmente de bronze, mármore, granito, metal, ou outro material, que pode trazer uma inscrição (v.) comemorativa, uma propaganda (v.), uma homenagem (placa de rua), etc. Pode ser também uma chapa que, emitida pela administração pública, representa sinal oficial de concessão de certas licenças e autorizações, como, por exemplo, a placa de carro ou de moto de metal que, colocada na dianteira ou na traseira de um veículo automotor, registra o número de licenciamento desse veículo. (grifo nosso)

Por sua vez, o cartaz é descrito por Costa (2008, p.44), como:

(...) anúncio (v.) ou aviso (v.) de dimensões variadas, muitas vezes ilustrado com desenhos ou com fotografias, apropriado para ser afixado em lugares públicos. Apresenta coerções genéricas semelhantes às de um outdoor (v.), porém, geralmente, é de dimensão menor.

No que concerne às diferenciações entre os moldes dos dois gêneros, podesedizer, portanto, que os cartazes são confeccionados em papel, ora impressos, ora escritos à mão, enquanto as placas apresentam-se produzidas em vários materiais como: placas de alumínio, madeira e, até mesmo, pintadas em muros ou paredes. 


\subsection{1}

\section{Placas e cartazes: oficiais e não oficiais}

Como podemos observar, o uso de avisos em placas e cartazes, com pequenas mensagens, orientando como proceder em determinados espaços, parece ser um instrumento muito comum em lugares de grande circulação de pessoas, como faculdades, prédios comerciais, banheiros públicos, lojas de conveniência, entre outros. Entretanto, há de se estabelecer diferenças entre os avisos veiculados em placas e cartazes expostos nesses espaços. Enquanto alguns deles são considerados não oficiais, surgindo da informalidade e da necessidade dos proprietários desses locais em evitar possíveis danos aos seus bens outros são considerados oficiais, isto é, regulamentados por leis federais, estaduais e municipais, a fim de que esses espaços funcionem corretamente, bem como para que o público que utiliza seus serviços e instalações tome conhecimento dos seus direitos e proibições. Estes últimos também sofrem frequentes fiscalizações pelo PROCON $^{4}$ e demais órgãos administrativos locais.

Portanto, diante da diversidade de avisos, é importante salientar que nosso trabalho optou por analisar apenas os avisos em suportes não oficiais, ou seja, aqueles que surgiram da informalidade e são consequência das transformações ocorridas ao longo do tempo na sociedade.

\section{3}

\section{Espaço público e espaço privado}

Refletir sobre a noção de espaço público e privado se faz relevante também neste trabalho, pois a configuração de tais territórios acaba por revelar na linguagem aspectos característicos desses espaços.

A princípio é necessário esclarecer alguns critérios de definições de tais termos, que podem confundir a apresentação dos dados, quando se combinam as questões de propriedade e uso. Com base no trabalho de Oliveira (2013), situado no âmbito da Arquitetura e Urbanismo, apresentamos na seguinte tabela exemplos

\footnotetext{
${ }^{4}$ Compete ao PROCON, Programa de Proteção e Defesa do Consumidor, executar a política estadual de defesa e proteção ao consumidor, promovendo em cada Estado os interesses e direitos dos consumidores.
} 
de diferentes espaços resultantes da combinação entre os tipos de propriedades e usos, com relação às esferas pública e privada.

\begin{tabular}{|c|c|c|}
\hline Propriedade & Uso & Exemplo \\
\hline Pública & Público & $\begin{array}{l}\text { Ruas, parque, praças, } \\
\text { instituições de ensino, } \\
\text { bibliotecas, centros } \\
\text { esportivos e culturais, } \\
\text { aeroportos, terminais de } \\
\text { ônibus, metrô ou trem, etc. }\end{array}$ \\
\hline Pública & Restrito & $\begin{array}{l}\text { Administrações públicas } \\
\text { dos governos, áreas de } \\
\text { segurança pública, } \\
\text { hospitais. }\end{array}$ \\
\hline Privada & Privado & $\begin{array}{l}\text { Residências, escritórios, } \\
\text { etc. }\end{array}$ \\
\hline Privada & Público & $\begin{array}{l}\text { Parques de diversões, } \\
\text { prestadores de serviços, } \\
\text { comércios, shopping } \\
\text { centers, jardins e praças de } \\
\text { propriedade privada, } \\
\text { pavimentos térreos de } \\
\text { edifícios, etc. }\end{array}$ \\
\hline
\end{tabular}

Quadro 1 - Relação entre tipo de propriedade privada e tipo de usos do espaço das cidades.

Assim, consideramos neste trabalho como um lugar público "um espaço aberto pertencente ao estado e livre de regulamentações" (Grolle, 2008, p. 41 apud Oliveira, 2013), isto é, um lugar onde qualquer um pode entrar e sem restrições, logicamente respeitando as leis do uso e segurança de bens públicos. Nesse grupo, ainda existem os espaços públicos com restrição ao acesso e à circulação; nestes a presença é controlada e restrita a determinadas pessoas, como os edifícios públicos (Prefeituras, Fóruns, residências oficiais de governantes), instituições de ensino, hospitais, entre outros. Já o espaço privado é demarcado e protegido por normas regulamentadas pelos proprietários particulares. Esse tipo de espaço pode 
não ser facilmente acessível a todo tipo de público, uma vez que o acesso e uso são regulamentados e limitados a certos números de pessoas.

Portanto, ao mencionarmos o espaço público e o espaço privado, no decorrer deste trabalho, estaremos nos referindo fundamentalmente aos locais físicos e às práticas espaciais neles estabelecidas cotidianamente. Não temos a pretensão de trabalhar, aqui, de forma mais aprofundada as dimensões do espaço público e privado, bem como as experiências que envolvem esses territórios. No entanto, temos a clareza de que tanto o espaço público quanto o privado são fundamentais na busca da legitimação de noções de cidadania, poder, hierarquia, etc., valores que perpassam também e, sobretudo, a língua, essencial mediador de práticas coletivas, assim como das contradições e dos conflitos. Sendo assim, os espaços não se traduzem simplesmente pela sua configuração de estruturas físicas, mas sim, enquanto espaços potenciais no processo de busca e construção pelo caminho da cidade.

\section{4}

\section{O tratamento dado às noções de pedido nas gramáticas tradicionais de PLM}

Ao analisarmos algumas gramáticas tradicionais de PLM, no que concerne aos usos dos atos de fala de pedir, contatou-se que há uma simplificação do assunto. De modo geral, estas apontam o uso do imperativo como o modo mais apropriado para exprimir os valores de ordem e pedido. Vejamos, a seguir, como tais noções são tratadas pelos seguintes autores: Cunha e Cintra (2008), Bechara (2009) e Lima (2010).

Cunha e Cintra (2008, p.491-496), em "Nova Gramática do Português Contemporâneo" afirmam que, embora a palavra imperativo esteja ligada, pela sua origem, ao latim imperare, que significa comandar; na maioria das vezes, não é para realizar uma ordem ou comando que utilizamos esse modo. Há outros meios mais eficazes do que o modo imperativo para expressarmos tais noções. Para os autores, o modo imperativo pode expressar diferentes valores: ordem, conselho, convite, solicitação, súplica ou hipótese. Esses diversos valores vão depender do significado do verbo, do sentido geral do contexto e da entonação que dermos à frase imperativa. Os autores também apontam para o fato de que o 
tom da voz pode mudar a noção de comando, a qual pode enfraquecer-se até chegar ao tom de súplica.

$\mathrm{Na}$ seção intitulada "Substitutos do imperativo", os autores,minuciosamente, apontam para o fato de que a língua nos oferece outros meios para exprimir os diversos matizes apresentados pelo imperativo. Entre esses meios está o uso do presente do indicativo e do futuro do presente para atenuar a rudeza da forma imperativa (Ex: O senhor me traz o dinheiro amanhã. / Tu irás comigo.), ou o uso do imperfeito do subjuntivo para transformar uma ordem numa simples sugestão (Ex: Se você se calasse!?). Ainda, podemos subordinar o verbo denotador da ação que deve ser cumprida a outro verbo, o qual marca a vontade do locutor (Quero que retornes ao colégio $=$ Retorna ao colégio). Além dos processos mencionados, a língua dispõe de variados recursos para reforçar ou atenuar a vontade expressa pelo imperativo. A eficácia desses recursos, porém, está sempre condicionada ao tom de voz, que é, nas formas afetivas da linguagem, um elemento essencial. Segundo Cunha e Cintra (2008), por dever social e moral, geralmente evitamos ferir a suscetibilidade de nosso interlocutor com a rudeza de uma ordem. Para enfraquecer a noção de comando ou autoridade, tendemos a utilizar algumas fórmulas de polidez, como, por exemplo, as expressões: por favor, por gentileza, tenha a bondade etc. No entanto, ainda que sejam utilizadas essas fórmulas de polidez, qualquer frase torna-se rude e seca, ou mesmo insolente, com uma simples mudança de entonação.

Além disso, os autores descrevem o uso do imperfeito de cortesia, isto é, o emprego do pretérito imperfeito no lugar do presente do indicativo, como forma de polidez para atenuar o ato de pedir (-Tive alta ontem, e vinha agradecer a V. Ex. ${ }^{a}$. - M. Torga, V, 279) (Cunha e Cintra, 2008: 466).

Bechara (2009), em sua Moderna Gramática Portuguesa, tece algumas considerações relacionadas ao uso do imperativo. Segundo o autor, este modo pode ser substituído pelo infinitivo nas ordens instantes, isto é, emprega-se o verbo no infinitivo e destaca-se a ação verbal no sentido de ordenar que uma ação seja realizada (Ex: "Todos se chegavam para o ferir, sem que a D. Álvaro se ouvissem outras palavras, senão estas: Fartar, rapazes" [AH.2,98]). Além disso, afirma que usamos o imperativo do verbo querer (ao lado do subjuntivo presente) seguido de infinitivo, para suavizar uma ordem (Ex: Queira aceitar meus cumprimentos). Já nos pedidos e solicitações, ou para manifestar um desejo feito 
com suavidade ou com um simples propósito, utilizamos o tempo verbal pretérito imperfeito (Ex: Sr. Manuel, eu desejava telefonar.). O autor também comenta que podemos exprimir uma ordem ou recomendação utilizando o futuro do presente, em lugar do imperativo, principalmente nas prescrições e recomendações morais (Ex: Defenderás os teus direitos; Não furtarás).

Em Lima (2010, p. 169), por sua vez, na Gramática Normativa da Língua Portuguesa, constata-se um tratamento bastante sucinto em relação aos outros gramáticos. Segundo o autor, o imperativo só tem um tempo - o presente -, que também se aplica às ordens que se dão para o futuro e para o passado. E acrescenta os seguintes exemplos: "Faça o que eu lhe digo. Faça o que eu the disser. Faça o que eu lhe disse". Sendo assim, deixa ainda mais vaga a noção de ordens e pedidos tão comumente utilizadas pelo brasileiro.

Como mencionado anteriormente, pesquisamos também trabalhos que tivessem se concentrado na investigação de atos de fala, especialmente de pedidos, dentro do contexto de ensino de português como língua estrangeira. Ao realizar uma busca com as expressões "pedido", "ensino de português" "língua estrangeira", constatamos que, durante o período da elaboração da dissertação, havia quatro trabalhos desenvolvidos e voltados para a investigação dos atos de pedir, motivados também pela prática do ensino de línguas.

Seguindo a ordem de publicação destes trabalhos, apresentamos inicialmente a dissertação de mestrado de Le Berre (2007), intitulada Formulações dos Atos Diretivos, em língua oral, no Português do Brasil. O trabalho objetiva descrever e analisar a formulação dos atos diretivos em português - nos quais se incluem ordens e pedidos - assim como as estratégias discursivas que atenuam ou reforçam o teor de imposição implicado na realização desses atos. Considerando a relevância dos atos diretivos na interação, em virtude da regularidade dos usos e das formas diversas em que se realiza, a autora justifica especialmente o desenvolvimento de seu estudo para ensino/aprendizagem do português como segunda língua (PL2E). Para Le Berre (2007), é fundamental compreender os aspectos linguísticos envolvidos na realização dos atos diretivos, visto que tais fenômenos são condicionados por fatores sociais e culturais; logo, exigem do falante competência para lidar com aspectos práticos da interação, entre elas a capacidade de negociação e compreensão das etapas que constituem, no caso, situações de pedidos e ordens. 
O segundo trabalho encontrado foi a dissertação de mestrado de Santos (2009), intitulada Ordem ou pedido? Como os brasileiros interpretam atos de fala produzidos por aprendizes de PLE. Também desenvolvida no campo de ensino de português para estrangeiros, essa pesquisa tem o propósito de investigar a produção oral de aprendizes de português, ao realizarem ordens e pedidos, e como os falantes nativos brasileiros interpretam essas produções quando proferidos pelos falantes estrangeiros. A escolha pelo tema, segundo Santos (2007), surgiu ao perceber que alguns falantes brasileiros consideravam os falantes estrangeiros de português como "ríspidos" em sua forma de pedir ou dar ordens. O efeito dessa percepção gerou conflitos na comunicação, bem como fortaleceram a ideia estereotipada de que estrangeiros são grosseiros, sobretudo quando estão em posição hierárquica superior à de seu interlocutor.

O terceiro trabalho que encontramos sobre o tema foi a tese de doutorado de Dias (2010) intitulada Estratégias de polidez linguística na formulação de pedidos e ordens contextualizados: um estudo contrastivo entre o português curitibano e o espanhol montevideano. O estudo objetiva analisar o uso de estratégias linguísticas de polidez na formulação de pedidos e ordens utilizadas no espanhol (montevideano) e no português (curitibano). A motivação para a realização do trabalho, segundo a autora, se deve ao contato com estudos pragmáticos, a prática docente no ensino de espanhol como língua estrangeira, além da ideia estereotipada de que falantes de língua espanhola utilizariam mais formas imperativas do que falantes do português brasileiro. Embora este estudo não esteja voltado para o ensino e aprendizagem, a autora reconhece que um aprendiz de língua estrangeira precisa dominar diferentes conhecimentos para ser comunicativamente competente. Sendo assim, considera que uma pesquisa como a sua, fundamentada nos princípios da Pragmática Intercultural, pode auxiliar professores de português e espanhol em suas próprias práticas, facilitando o desenvolvimento das competências sociolinguística e pragmática do aprendiz, a partir de um maior conhecimento sobre o funcionamento das línguas.

O quarto trabalho que analisamos foi a dissertação de mestrado de Spadotto (2016) intitulada Ordens e pedidos em língua italiana: um estudo da percepção de falantes nativos e aprendizes brasileiros a partir da teoria dos atos de fala. $\mathrm{O}$ objetivo deste estudo foi investigar ordens e pedidos em língua italiana, identificando os elementos que caracterizam e diferenciam esses dois atos 
de fala, segundo a percepção de falantes nativos e de brasileiros aprendizes de italiano. A escolha pelo tema surgiu da própria experiência da autora como professora de italiano no Brasil, onde pôde observar, durante as atividades propostas, que seus alunos brasileiros optavam pelo uso de estruturas menos diretas em lugar do imperativo, mesmo quando eram incentivados a utilizar tal modo. Além disso, ao investigar ordens e pedidos, segundo a autora, é possível, do ponto de vista linguístico, abordar o estereótipo segundo o qual os italianos seriam pessoas mais autoritárias do que os brasileiros. Para Spadotto (2016), é importante suscitar essas reflexões aos aprendizes de língua estrangeira e levar para a sala de aula fenômenos reais da língua, a fim de estimular a capacidade de reconhecer elementos do ato comunicativo que transcendem a estrutura formal da língua, e entre tantas opções estão as nuances que envolvem os atos de fala ordens e pedidos.

Além de os trabalhos mencionados investigarem os mesmos atos de fala, eles partem de problemas similares que resultam da estreita ligação que há entre língua e cultura. Esses estudos evidenciam que, para o aprendizado que objetiva a comunicação eficaz, são necessárias análises e investigações voltadas ao desenvolvimento de competências que não se limitem aos aspectos estruturais da língua. Além do mais, evidenciam a necessidade de estudos que desconstruam, por meio da observação de dados empíricos, visões estereotipadas - por vezes motivadoras de preconceito e discriminação - e favoreçam o entendimento das culturas em seus diferentes aspectos e o respeito à diversidade.

É com base nesse contexto, e principalmente a partir dessas considerações, que justificamos o desenvolvimento deste estudo. Acreditamos que a partir da observação dos dados seja possível levar à sala de aula amostras de situações reais de uso da língua e identificar o que ensinar aos aprendizes de PL2E para estimular a capacidade de reconhecer elementos do ato comunicativo que ultrapassam a estrutura formal da língua. 


\section{Pressupostos Teóricos}

Dado que este estudo não se dispõe a tecer reflexões baseadas em uma concepção de língua stricto sensu, mas a uma noção de língua também vinculada ao contexto sócio-cultural, sendo, esta, reveladora de um modo particular e peculiar de perceber o mundo e seu entorno, optou-se por uma abordagem teórica interdisciplinar. Assim sendo, este trabalho se realiza à luz das seguintes correntes teóricas: a Teoria dos Atos de Fala, a Sociolinguística Interacional, o Interculturalismo e a Antropologia Social.

A escolha dessa abordagem para o nosso trabalho se deve ao fato de as referidas áreas de estudo fornecerem conceitos que nos ajudam a reconhecer e a interpretar as estratégias linguísticas utilizadas pelos falantes, para realizar atos de pedido em diferentes contextos interacionais.

Da Teoria dos Atos de Fala de Austin (1962), fazemos uso do conceito de ato de fala ilocucionário diretivo e dos diferentes modos de realizar um ato de fala, os quais podem ser divididos em três níveis: direto, indireto convencional e o indireto não-convencional (Searle, 1984); associados a esses conceitos consideramos a categorização dos tipos de estratégias do ato de pedir propostas por Blum-Kulka e Olshtain (1984).

Da Sociolinguística Interacional, utilizamos os conceitos de face, analisados por Goffman (1971) e recuperados por Brown e Levinson (1978; 1987); além dos conceitos de polidez positiva, negativa e indiretividade, abordados por estes, e por Blum-Kulka (1987).

Dos Aspectos Interculturais, adotamos os conceitos: culturas de alto contexto e de baixo contexto de Hall (1998); as dimensões culturais Evitação de Incerteza e Individualismo vs. Coletivismo de Hofstede (2010).

Quanto ao referencial teórico da Antropologia Social, fazemos uso dos conceitos de casa e rua, indivíduo e pessoa, de DaMatta (1997).

Acrescentam-se ainda considerações a respeito de alguns aspectos da cultura brasileira, especialmente debatidos por Meyer (1999, 2008, 2013) e Mendes $(2011,2015)$. 


\section{1}

\section{A Teoria dos Atos de Fala}

A Teoria dos Atos de Fala, delineada inicialmente por Austin (1962), baseia-se no fato de que a linguagem é um instrumento de ação sobre a realidade, ou seja, de que fazemos coisas ao usarmos as palavras.

Esta nova forma de olhar a linguagem demonstra que a língua não consiste em um simples "veículo de pensamentos e ideias", mas que "ela se concretiza através de sentenças produzidas no discurso, a fim de desempenhar funções ou ações sociais" (Gutierres, 2008, p. 196). A essas ações sociais, tais como: fazer pedidos ou promessas, desculpar-se, dar ordens, fazer afirmações, entre outros; dá-se o nome de atos de fala.

De acordo com Austin, a produção de um ato de fala envolve, de forma simultânea, a produção de três tipos de atos:

a. Ato locucionário: é o simples fato de dizer algo, ou seja, é o ato de produzir uma expressão linguística com significado;

b. Ato ilocucionário: é a realização do ato em si, refere-se à intenção com que o falante formula uma sentença, em vista do propósito comunicativo que busca atingir, como pedir, cumprimentar, censurar, prometer etc.

c. Ato perlocucionário: é o que causa efeito no ouvinte em função da emissão de um ato de fala, como influenciar o outro, persuadi-lo a fazer algo, causar um embaraço ou constrangimento, etc.

Para fins de ilustração, quando o falante enuncia “Amanhã será um grande dia" seja em qual contexto for, na modalidade falada ${ }^{5}$ ou escrita, ele está produzindo um ato locucionário, ou seja, ele está emitindo os sons, organizando as palavras em conformidade com as regras gramaticais vigentes da sua língua. Com este mesmo enunciado, o falante poderá realizar, dependendo da intenção e do contexto, um ato ilocucionário de advertir, comunicar, intimidar, entre outros. É o que pode ocorrer, por exemplo, quando um falante diz “Amanhã será um

\footnotetext{
${ }^{5}$ A Teoria dos Atos de Fala, como o próprio nome diz, originalmente foi criada em função da modalidade falada; atualmente, sua aplicação foi ampliada para a escrita. Disponível em: < http://biblioteca.virtual.ufpb.br/files/pragmatica_1360183162.pdf $>$. Acesso em: 15 jun. 19.
} 
grande dia" com a intenção de chamar atenção para o momento de chegada de algo que se espera há muito tempo, ou ainda, para fazer uma ameaça ou um lembrete ao seu interlocutor. Este ato de fala, portanto, pode causar o efeito de agrado ao ouvinte, mas também pode ter um efeito ameaçador. Estes efeitos provocados ao interlocutor correspondem ao ato perlocucionário, não linguístico, que produz e exerce influência sobre os pensamentos, sentimentos e ações.

Caracterizados os atos de fala, Austin (1962) direcionou seus estudos para os atos ilocucionários, uma vez que o objetivo desse ato seria o de realizar ações. Para ele, tais atos são dotados de uma força, que ele denomina de força ilocucionária. Essa força advém de alguns verbos que estão subdivididos em cinco categorias, a saber:

a. Veridictivos - fazem julgamentos fundamentados em evidências ou dão vereditos, como analisar, descrever, condenar, decretar, declarar inocência, etc.;

b. Exercitivos -denotam exercício de poder, direitos ou influência, como ordenar, exortar, recomendar, perdoar, etc.;

c. Comissivos - o falante se compromete a fazer algo ou anuncia sua intenção de fazer algo, como prometer, garantir, jurar, etc.;

d. Comportamentais - estão relacionados a atitudes e comportamentos sociais como desculpar-se, agradecer, criticar, etc.;

e. Expositivos - usados para expor um ponto de vista, conduzir argumentação, como afirmar, negar, admitir, explicar, etc.

Como o próprio Austin (1962) admite, essa classificação não é plenamente satisfatória e por isso necessitava de estudos mais aprofundados, pois alguns verbos poderiam pertencer a mais de uma categoria. Apesar de algumas lacunas deixadas no processo de construção de sua teoria, suas ideias foram fundamentais para motivar o surgimento de uma nova concepção de linguagem. Assim, coube a Searle ampliar e sistematizar as ideias de Austin posteriormente.

Em seu livro Speech Acts $^{6}$, Searle retoma questões importantes concernentes à teoria dos atos de fala (também denominados pelo autor de atos

${ }^{6}$ Atos de fala 
linguísticos ou atos de linguagem). Ele mantém os pressupostos básicos de Austin de que tais atos são unidades básicas da comunicação linguística e de que cada ato de fala envolve a realização de atos distintos ao mesmo tempo. Contudo, modifica a noção de ato ilocucionário de Austin (1962), agregando as noções de ato de enunciação - ação de enunciar uma sequência de palavras - e a de ato proposicional - o ato de referir e predicar (Searle, 1981, p. 34-35). Observemos a seguinte sentença para exemplificar essa diferenciação,

a. A despensa está vazia.

Ao proferirmos as palavras que compõem essa sentença, temos um ato de enunciação realizado. Ao mesmo tempo, também temos um ato proposicional, isto é, que se faz referência a um objeto do mundo real: "a despensa", e predica-se algo sobre este objeto: "está vazia". Também podemos afirmar que com este enunciado podem-se realizar diferentes atos ilocucionários, uma vez que o falante, dado o contexto em que se encontra, poderia estar fazendo uma solicitação indireta para que alguém vá ao mercado, ou até mesmo uma queixa, se o interlocutor, responsável por fazer as compras, não tiver cumprido com sua obrigação, por exemplo.

É importante estabelecer a diferenciação entre ato proposicional e ato ilocucionário, pois é possível perceber que diferentes sentenças podem compartilhar semelhante conteúdo proposicional e realizar diferentes atos de fala. Vejamos:

b. A despensa está vazia. > pedido, afirmação ou reclamação.

c. A despensa está vazia! > afirmação com surpresa.

d. A despensa está vazia? > pedido de informação.

e.Tomara que a despensa esteja vazia. > demonstração de desejo (caso o falante precise de espaço na despensa)

A partir das categorizações de Austin, Searle (1969) propõe novos critérios para a classificação dos atos ilocucionários e apresenta a seguinte tipologia (Kerbrat-Orecchioni, 2005, p.32): 
a. Atos representativos - mostram a crença do falante com a verdade da proposição expressa (afirmar, dizer, concluir, etc.);

b. Atos diretivos - consistem nas tentativas de conseguir que o ouvinte faça algo (ex.: pedir, mandar, rezar, etc.);

c. Atos comissivos - comprometem o falante com a realização de uma ação futura (ex.: prometer, jurar, garantir, etc.);

d. Atos expressivos - consistem em exprimir sentimentos, estados psicológicos (ex.: agradecer, parabenizar, desculpar-se etc.);

e. Atos declarativos - produzem uma mudança em algum estado de coisas, geralmente institucionalizada - batizar alguém, condenar, demitir, etc.

Embora renomeie a maioria dos atos de Austin (op. cit.), Searle (1981) mantém as principais características da classificação do autor, sendo os atos exercitivos, comissivos e comportamentais correspondentes aos atos diretivos, comissivos e expressivos de Searle, respectivamente, enquanto os representativos seriam a reunião das características dos veridictivos e dos expositivos. Por outro lado, os declarativos não estão relacionadas a nenhuma das cinco categorias austinianas. Eles estão ligados ao que Austin, inicialmente, considerou como enunciados performativos.

Tais classificações nos levam a concluir que os atos ilocucionais têm variados graus de força, desempenham diferentes funções e, consequentemente, conduzem a múltiplas interpretações. A realização desses atos só é possível de acordo com as escolhas adequadas de uso dos elementos linguísticos que, reunidos, estruturam o sentido de um enunciado. Entretanto, tais escolhas de uso dependem de dados culturais, os quais podem diferir de cultura para cultura e, portanto, devem ser ensinados e contextualizados a um estrangeiro alheio à nova cultura a que está exposto.

Nessa perspectiva, Searle identifica várias condições de felicidade a que um enunciado deve obedecer, a fim de cumprir o seu objetivo ilocucionário, e se interessa pelas diversas formas, diretas e indiretas, de realizar um ato de fala. Segundo o autor, ascondições de felicidade são: (i) a condição preparatória; (ii) o conteúdo proposicional; (iii) as condições de sinceridade e (iv) a condição essencial. 
Considerando, portanto, a Teoria dos Atos de Fala desenvolvida por Austin (1990) e posteriormente aperfeiçoada por Searle (1982), ao formularmos um pedido realizamos, na maioria das vezes, um ato de fala diretivo cuja força ilocucionária é propriamente o desejo do cumprimento das respectivas ações. Entretanto, é importante mencionar que - dentro dos contextos propostos nesse estudo - é possível, também, fazer solicitações com o intuito de evitar desconfortos, através de um ato de fala expressivo (Eu não posso vender fiado pelo amor de Deus) ou, ainda, pedir ao interlocutor que tenha atitudes de bom comportamento através de um ato de fala declarativo (Seja um bom cidadão: recolha o cocô do seu cão).

\subsection{1}

\section{Caracterização de pedidos como Atos de Fala}

Segundo a classificação de Searle (1984), o pedido é um ato ilocucionário diretivo. Os atos diretivos, de acordo com o autor, são tentativas por parte do falante de fazer com que o ouvinte faça alguma coisa. O falante realiza a ação de pedir ou de ordenar, ou de solicitar, com maior ou menor grau de diretividade, tentando convencer o interlocutor a alterar o seu comportamento em benefício do próprio falante.

Um ato de fala diretivo só será bem sucedido ou feliz se o ouvinte identificar a intenção daquele que fala e executar o ato conforme sua solicitação. Desse modo, os pedidos apenas serão felizes se preencherem determinadas condições de adequação, assim como as citadas anteriormente (condições de conteúdo proposicional, preparatórias, de sinceridade e essenciais).

Os atos diretivos subdividem-se em duas categorias:

a. Diretos: que declaram de forma explícita uma proposição e a intenção do falante. Não são necessárias deduções por parte do ouvinte para determinar a força ilocucionária do ato de fala proferido pelo falante. Um exemplo seria: "Fique aqui”.

b. Indiretos: que não declaram de forma explícita uma proposição. Torna-se necessário, nesse caso, a realização de inferências para chegar-se à força 
ilocucionária do ato de fala proferido. Um exemplo seria: "Você se importaria de ficar aqui?"”.

No caso dos atos diretos, o falante profere um enunciado em que as palavras significam literalmente o que ele quer dizer em dado contexto. Já nos indiretos, o falante profere um enunciado onde há mais de uma força ilocucionária envolvida em jogo. Ao dizer "Você se importaria de ficar aqui?", o falante não está questionando a vontade do seu ouvinte, mas fazendo um pedido para que este aguarde. Os casos em que o enunciado possa vir a apresentar mais de uma força ilocucionária devem ser considerados diferentemente daqueles casos em que o falante simplesmente diz ao ouvinte, de forma transparente e explícita, que deseja que ele faça algo. Nos atos indiretos, o falante comunica ao ouvinte mais do que realmente diz. Para Searle (1995, p.6), a questão relacionada aos atos de fala indiretos é saber como é possível o falante dizer alguma coisa e querer significála, mas querer, sobretudo, significar algo mais.

Por outro lado, uma questão ainda maior é, justamente, saber como um ouvinte é capaz de compreender um ato de fala indireto. Além do mais, há enunciados que parecem ser empregados como pedidos indiretos de uma maneira simplesmente convencional. Searle (1995) então conclui que o falante pode expressar ao ouvinte mais do que realmente diz, com base no conhecimento, tanto linguístico quanto de mundo, compartilhado por ambos. O ouvinte, deste modo, compreende o ato de fala fazendo uso de sua capacidade de racionalidade e inferência. $\mathrm{O}$ autor ainda salienta que algumas formas poderão ser convencionalmente estabelecidas como formas idiomáticas padrão para os atos de fala indiretos. Mesmo permanecendo com seus significados literais, adquirirão usos convencionais como, por exemplo, formas polidas para pedidos. De acordo com Searle, "Você pode", "Você poderia", "Eu quero que você", "Eu gostaria que você", são alguns exemplos de meios convencionais de fazer pedidos.

O interesse por questões de cunho pragmático, como essas, fez com que um grupo de linguistas, liderado por Shoshana Blum-Kulka (Hebrew University, Jerusalen) e Elite Olshtain (Tel Aviv University) em 1984, decidisse realizar uma investigação pragmática contrastiva focalizando padrões interculturais de realização de atos de fala. Este projeto foi nomeado CCSARP (Cross-Cultural Study of Speech Act Realization Patterns) e debruçou-se sobre dois atos de fala: 
'pedidos' e 'desculpas', cuja análise foi feita em oito línguas estudadas pelos integrantes do projeto.

Os três principais interesses dos participantes do projeto era verificar a:

a. Variabilidade Situacional: estabelecer padrões dos dois atos de fala por falantes nativos em relação a diferentes contextos sociais.

b. Variabilidade Individual (nativo versus não nativo): estabelecer as semelhanças e diferenças entre modelos de realização de solicitações e pedidos de desculpas de nativos e não nativos referentes à mesma situação.

c. Variabilidade Intercultural: estabelecer as semelhanças e diferenças dos modelos de realização do ato de solicitar e do ato de pedir desculpas interlinguisticamente, referentes à mesma situação constrangedora entre as línguas analisadas.

O modelo teórico e metodológico adotado para a investigação foi desenvolvido pelos participantes do projeto, que seguiram semelhante abordagem na coleta e análise de dados. Os autores desenvolveram um procedimento de elicitação, o DCT (Discourse Completion Test), cujo objetivo era o de coletar dados para serem utilizados em estudos interlinguísticos, bem como investigar questões sociolinguísticas e pragmáticas encontradas por aprendentes de uma L2.

Uma vez tendo de maneira breve e sucinta falado sobre o projeto de BlumKulka e Olshtain (1984), vamos agora concentrar nossa atenção no seu modelo de análise de pedidos.

\subsubsection{1}

\section{Definindo as unidades de análise}

Para poderem analisar os pedidos como atos de fala, Blum-Kulka e Olshtain (1984:200) dividiram os pedidos em três segmentos:

a. Termo de endereçamento: a quem e como o falante se dirige ao fazer o pedido.

b. Ato principal: é o pedido em si, é o núcleo do pedido. 
c. Adjunto(s) ao Ato Principal: auxiliares de articulação do pedido, podendo minimizar o pedido em si, ou agravá-lo.

Exemplo:
A
B
$\mathrm{C}$
$\mathrm{D}$

Dani/ você poderia me emprestar $\mathrm{R} \$ 100,00$ esta semana/ Eu tive problemas/ e não pude pagar o aluguel.

A sequência poderia ser separada em quatro partes:
A. 'Dani' - termo de endereçamento;
B. 'você poderia me emprestar $\mathrm{R} \$ 100,00$ esta semana' - ato principal;
C. 'Eu tive problemas' - ato adjunto ao ato prinicipal;
D. 'e não pude pagar o aluguel.' ato adjunto ao ato pinicipal.

Como demonstra o exemplo anterior, um pedido pode incluir diferentes sequências de enunciados, cada qual com uma função específica: alertas, atos de apoio e atos principais (Blum-Kulka et al., 1989b, p. 17). Passemos a detalhar o que caracteriza cada uma dessas sequências.

a. Alertas (alerters) - os alertas funcionam como chamadores de atenção e são várias as categorias de termos usados nessa função. Eles podem ser subdivididos em: (a) marcadores formais, como 'com licença' 'por favor', 'desculpe' e os vocativos 'senhor/senhora'; (b) marcadores informais, que buscam aproximação, como nomes, apelidos, etc. e (c) os cumprimentos (Boa tarde! Como vai?). Entre os alertas, temos os 'termos de endereçamento', sequência já identificada acima.

b. Atos de apoio (suppositive moves) - São unidades externas ao pedido que modificam o seu impacto, a fim de suavizar ou intensificar a força do enunciado. Deste modo, os pedidos normalmente são antecedidos pela verificação de disponibilidade (Você está ocupado?) e/ou perguntas como "você poderia me fazer um favor" para obter um comprometimento prévio do interlocutor. Ainda, podem também ser precedidos de justificativas, promessas e até de ameaças para persuadir o interlocutor a fazer algo. Blum-Kulka et al. (1989b, p. 17) apontam 
também que muitas vezes certos atos de apoio, como a justificativa, podem se constituir como pedidos sozinhos, como em "acho que deixei minha caneta em casa" e obter como resposta "quer a minha caneta emprestada?". Entre os atos de apoio inclui-se a sequência de 'ato adjunto ao ato principal'.

c. Atos principais (head acts) - é aquela parte da sequência que pode servir para realizar o ato independentemente de outros elementos. Em outras palavras, é a unidade mínima que realiza o pedido. Esses atos, pela categorização proposta por Blum-Kulka et al., podem ser distinguidos entre modificadores externos e modificadores internos ao ato principal. Enquanto os modificadores externos são aqueles que fazem uso de atos de apoio (como, por exemplo, as justificativas e os pré-pedidos), os modificadores internos são elementos lexicais que estão ligados ao ato principal, podendo atenuá-lo ou intensificá-lo, mas que não são essenciais para que o enunciado seja compreendido como um pedido. Como exemplos de atenuadores lexicais e frasais têm-se as formas consultativas, que envolvem o ouvinte de modo a convencê-lo a cooperar, a efetivar o pedido (Você acha que poderia fazer $x$ ?) e os diminutivos, elementos através dos quais o falante minimiza sua proposição (Você poderia fechar a janela um pouquinho?). Há ainda como forma de modificação interna os atenuantes sintáticos, com seus diferentes tipos, tempos e modos verbais, tais como "gostaria" e "pode", que contribuem para atenuar o grau de imposição de uma ordem ou pedido. A escolha da perspectiva é outro aspecto importante que apresenta variações nos pedidos, podendo ser orientada para o falante (Posso pegar sua blusa emprestada?) ou ter o foco direcionado para o ouvinte (Você pode me emprestar sua blusa?). Os pedidos ainda podem ser formulados como inclusivos, quando o pedido está direcionado a ambos: falante e ouvinte (Podemos limpar o quarto agora?), ou impessoais (O quarto precisa ser arrumado). De acordo com Blum-Kulka et al. (1989b, p. 19), todas essas opções estão disponíveis frequentemente para os falantes em uma determinada situação, no entanto não estão necessariamente para a mesma estratégia.

As seções posteriores aprofundam a abordagem daquelas categorias que serão consideradas nas análises de nossos dados. Vejamos a seguir. 


\subsubsection{2}

\section{Tipos de Estratégia}

Blum-Kulka e Olshtain (1984, p. 201) citam que houve várias tentativas em trabalhos teóricos e empíricos como os de Searle (1975), House e Kasper (1981) e Blum-Kulka (1984) para tentar classificar as estratégias utilizadas para formar uma escala linguisticamente válida de diretividade.

Segundo os autores, existem três níveis mais abrangentes de diretividade que podem ser universalmente manifestados nas estratégias de pedidos.

a. A mais direta, ao nível explícito - são realizadas por pedidos sintaticamente marcados como o imperativo, ou através de outro meio verbal que dê nome ao ato de um pedido, tais como os performativos (AUSTIN, 1962).

b. Nível indireto convencional- procedimentos que realizam o ato através de referências às pré-condições contextuais necessárias para a sua realização, como convencionadas numa determinada língua. Um exemplo seria: pedidos iniciados por “você poderia fazer isto?" ou "faria o favor de fazer isso?".

c. Nível indireto não convencional - seriam as estratégias indiretas que realizam o pedido por referências parciais a objetos ou elementos necessários para a realização do ato, tais como sugestões, assim como em "Por que a janela está aberta?", ou se apoiar em pistas contextuais como em “está frio aqui".

Baseado no trabalho empírico com pedidos nas diferentes línguas, BlumKulka e Olshtain (1984) subdividiram esses três elementos em nove subníveis nomeados "tipos de estratégia", formando uma escala que mede a indiretividade do ato de fala, indo da mais direta à mais indireta. Estes são: 
Quadro 2 - Tipos de estratégias de pedidos

Tipos de estratégias

Exemplos de realizações linguísticas

\begin{tabular}{|c|c|}
\hline $\begin{array}{l}\text { 1. Modo derivável } \\
\text { Representa a categoria mais direta. O modo } \\
\text { gramatical do verbo determina sua força } \\
\text { ilocucionária como um pedido. O imperativo é a } \\
\text { forma prototípica, porém não é a única, há } \\
\text { equivalentes funcionais, como as formas infinitivas } \\
\text { e as estruturas elípticas que expressam o mesmo } \\
\text { nível de diretividade. }\end{array}$ & $\begin{array}{l}\text { 'Feche a porta' } \\
\text { 'Faz favor de abrir a porta' }\end{array}$ \\
\hline $\begin{array}{l}\text { 2. Performativo explícito } \\
\text { A força ilocucionária da sentença é explicitamente } \\
\text { marcada pelo falante ao usar um verbo } \\
\text { ilocucionário relevante. }\end{array}$ & 'Eu estou pedindo para você fechar a porta'. \\
\hline $\begin{array}{l}\text { 3. Performativo atenuado } \\
\text { O verbo que evidencia a força do pedido é } \\
\text { modificado por verbos modais ou verbos que } \\
\text { denotam intenção. }\end{array}$ & $\begin{array}{l}\text { 'Eu devo/tenho que pedir para você fechar a } \\
\text { porta'. }\end{array}$ \\
\hline $\begin{array}{l}\text { 4. Declaração de obrigação } \\
\text { Enunciados que expressam a obrigação do ouvinte } \\
\text { de cumprir determinado ato. A força ilocucionária } \\
\text { resulta diretamente do significado semântico da } \\
\text { locução. }\end{array}$ & 'Você deve/ tem que fechar a porta'. \\
\hline $\begin{array}{c}\text { 5. Declarações de vontade } \\
\text { Enunciados que declaram que o falante deseja que } \\
\text { o episódio representado na proposição seja } \\
\text { realizado. }\end{array}$ & 'Eu gostaria que você fechasse a porta'. \\
\hline $\begin{array}{l}\text { 6. Fórmulas sugestivas } \\
\text { O propósito ilocucionário é formulado como uma } \\
\text { sugestão através de fórmulas de rotinas. }\end{array}$ & 'Que tal fecharmos a porta?' \\
\hline $\begin{array}{c}\text { 7. Indagações preparatórias } \\
\text { O falante faz uso de enunciados que contenham } \\
\text { estratégias preparatórias para a realização do } \\
\text { pedido, normalmente relacionadas à disposição ou } \\
\text { possibilidade de que o pedido em questão seja bem } \\
\text { sucedido. }\end{array}$ & 'Você poderia fechar a porta?' \\
\hline $\begin{array}{c}\text { 8. Pistas fortes } \\
\text { O enunciado contém referência a elementos } \\
\text { relevantes do ato ilocucionário pretendido. As } \\
\text { insinuações não são formas convencionalizadas, } \\
\text { portanto, necessitam de maiores inferências por } \\
\text { parte do ouvinte. }\end{array}$ & 'A porta está aberta'. \\
\hline $\begin{array}{l}\text { 9. Pistas moderadas } \\
\text { O enunciado não faz qualquer referência ao pedido } \\
\text { propriamente dito, mas pode ser interpretado } \\
\text { através do contexto como pedidos. }\end{array}$ & 'Está frio aqui'. \\
\hline
\end{tabular}

Quadro adaptado de Blum-Kulka e Olshtain (p. 202, In: Applied Linguistics v. 5, 1984). 
Conforme o quadro acima, há nove tipos de estratégias que podem ser utilizadas no caso dos atos de fala diretivos: as cinco primeiras são consideradas estratégias diretas, ou impositivas; as duas seguintes, indiretas convencionais e as duas últimas, indiretas não convencionais. Esta classificação das estratégias mencionada acima será utilizada para fazer a análise dos pedidos e ordens em avisos presentes nas placas e cartazes.

\subsubsection{Atenuantes gramaticais e lexicais}

As línguas dispõem de uma série de recursos linguísticos que podem contribuir para aumentar o efeito de polidez ao realizar-se um pedido ou uma ordem, uma vez que atenuam "o dito" e, indiretamente, também "o dizer". Blum-Kulka e Olshtain (1984) apontam que um dos modos de minimizar tais atos é o uso dos atenuantes sintáticos, tais como:

a. Sentenças interrogativas: 'Você poderia abrir a porta?'.

b. Negação: 'Será que você não se importaria de abrir a janela?'.

c. Tempo verbal no passado: 'Eu precisava sair um pouco mais cedo hoje'.

d. Oração condiconal: 'Eu vou ficar contente se você abrir a porta'.

O uso desses mitigadores sintáticos pode comunicar diferentes atitudes. Por exemplo, o falante pode querer denotar pessimismo em relação ao resultado do pedido (uso de negação), distanciamento (uso do verbo no passado) ou ainda hesitação ao usar a forma "poderia" em vez de simplesmente "pode".

Blum-Kulka e Olshtain (1984) também classificaram outras modificações possíveis de que o falante se utiliza para atenuar a força impositiva do ato. Os exemplos citados nestes itens são todos adaptados de Blum-Kulka e Olshtain (1984) pela autora. São eles:

a) Marcadores de polidez - Elementos linguísticos opcionais que o falante acrescenta para conseguir a colaboração do ouvinte, como as expressões: "por favor" e seus derivados como "faz favor", "fazendo um favor" e "por gentileza", que frequentemente aparecem com essa função. O uso de "por favor" em posição inicial pode adquirir um valor de chamada de atenção (alerta), ou até mesmo uma forma de desculpa pela intromissão. 
b) Expressões de consulta - São aquelas expressões que servem para envolver o interlocutor consultando sua opinião sobre determinado tema (ex: "você acha que ...", "sabe se ...").

c) Minimizadores - Elementos através dos quais o falante minimiza parte de sua proposição, através do uso de advérbios como em "Você poderia arrumar um pouco antes de eu começar?" ou diminutivos "Eu posso te dar um conselhinho?".

d) Hedge - Um tipo de mitigador adverbial ao qual o falante recorre para evitar ser claro ou preciso. Podemos citar "tipo", "de um modo geral", "de certa forma".

e) Mitigações adverbiais (understater) - Modificadores adverbiais por meio dos quais o falante minimiza o estado de coisas denotado na proposição ("um momento", "um pouco", “apenas", "só”, "rápido", etc.).

f) Moduladores (downtoner) - Modificadores por meio dos quais os falantes atenuam o impacto que o seu enunciado pode causar no ouvinte. Usam-se termos como “provavelmente", "talvez", etc.

g) Fórmula de assentimento (appealer) - O falante busca o assentimento ou acordo do ouvinte quanto ao ato realizado. No português brasileiro, formas como "ok?”, “tá?” e "tá bom?" exercem essa função.

\section{2}

\section{Conceitos da Sociolinguística Interacional}

É da conexão entre língua e sociedade que se ocupam os estudos da Sociolinguística Interacional, corrente teórica que parte do princípio de que a língua não é uma entidade abstrata, autônoma que independe do contexto situacional, da cultura e da história das pessoas que a utilizam como meio de comunicação; ela é, sobretudo, uma instituição social. Com sua natureza interdisciplinar, por fazer interface com outras áreas, como a Antropologia, a Sociologia e a Linguística, a abordagem focaliza seu estudo no uso da língua em interações reais, e para bem descrevê-la ancora sua pesquisa no método qualitativo e interpretativo de 
análise, que leva o pesquisador a responder à seguinte questão: “O que está acontecendo nesta 'situação social'" ?

Desenvolvida a partir dos estudos de John Gumperz e Erving Goffman, a abordagem compreende a relação entre língua e sociedade a partir do uso da fala em contextos sócioculturais específicos, podendo considerar tanto gêneros mais espontâneos como uma conversa entre amigos, quanto as interações mais gerais, produzidas em contextos institucionais, como um sermão religioso, uma consulta médica, uma entrevista, um debate acadêmico, uma aula, dentre outros (Ribeiro \& Garcez, 2002).

É importante salientar que a Sociolinguística Interacional, em linhas gerais, enfatiza e focaliza o conhecimento sócio-cultural que se constrói e se expressa nas interações face a face. No entanto, ampliamos essa perspectiva neste estudo, considerando, assim como defende Marcuschi, que a "interação face a face não é condição necessária para que haja uma conversação" (2003, p.15). Como mensagem, que coloca seres humanos em uma relação de comunicação, os avisos em placas e cartazes exigem, além da compreensão, também o cumprimento do que é solicitado. E essa interação só é possível através dos elementos verbais - em alguns registros marcados por traços típicos da fala menos formal - e não-verbais, que se encontram dispostos nestes suportes.

Com vasto referencial teórico dentro desta área, a opção em utilizar neste estudo os trabalhos desenvolvidos por Erving Goffman e Brown \& Levinson (1987) se deve pela abrangência de suas teorizações, além do alinhamento de algumas de suas noções com a temática desenvolvida. Apresentamos, a seguir, alguns conceitos importantes para a análise dos nossos dados.

\subsection{1}

Face

Em seu estudo de natureza sociológica sobre os rituais de interação, Goffman explicita a necessidade de se analisarem, com rigor, as relações sociais que se estabelecem entre os indivíduos, quer nos encontros imediatos quer nas comunicações indiretas, pois para ele "toda pessoa vive em um mundo de encontros sociais, que a põe em contato, seja este face a face ou mediado, com outros participantes" (Goffman, 1980, p. 76). Em cada um desses contatos, o

${ }^{7}$ Goffman considerava fundamental nos estudos sociolinguísticos: a "situação social”, definida como "um ambiente que proporciona possibilidades mútuas de monitoramento, qualquer lugar em que um indivíduo se encontra acessível aos sentidos nus de todos os outros que estão 'presentes', e para quem os outros indivíduos são acessíveis de forma semelhante" (2002, p. 17). 
locutor procura causar uma imagem positiva no seu interlocutor, de modo a ser aprovado por ele. Quanto mais positiva for essa imagem, mais os outros a aceitarão. Goffman denominou esta noção de face, em que

o termo face pode ser definido como um valor social positivo que uma pessoa reclama para si mesma através daquilo que os outros presumem ser a linha tomada por ela durante um contato específico. Face é a imagem do eu delineada em termos de atributos sociais aprovados (...) (Goffman, 1967, p. $5)$.

A partir da afirmação, fica claro, que o que Goffman chama de face é algo muito mais do que o rosto, mas é toda a fachada que sustenta um indivíduo. Conforme, observa Gastaldo, "Face é o esforço que cada um de nós faz para manter-se à altura da dignidade que projetamos sobre nós mesmos, à altura do tratamento que acreditamos merecer por parte dos outros". (2008, p. 151). Sendo assim, a face é uma auto-imagem, enraizada na aprovação social do eu. É uma noção que somente faz sentido quando encarada em termos sociais e interacionais, em virtude do fato de que o sujeito vai construindo a sua própria imagem com base nas reações dos outros à sua atitude. Por isso, apesar de pessoal, a face resulta do convívio social e, nesse sentido, pertence também à comunidade em que o sujeito está inserido. Logo, pode-se afirmar que a face é algo que não está sob o controle do indivíduo, pois ela é, efetivamente, construída no outro.

Nessa perspectiva, há sempre um esforço por parte das pessoas em prol da preservação da face, que se torna então condição da interação. Cada eu, aos poucos, cria o seu próprio espaço e tenta desenvolvê-lo, evitando desestabilizar a ordem já estabelecida. O indivíduo vai assim se autorregulando, de forma a não pôr em risco nem o equilíbrio social, nem a própria face, a fim de que os envolvidos na interação atinjam seus objetivos, mesmo que estes sejam motivados por interesses distintos.

É bem verdade que todo o indivíduo pretende manter uma face positiva e assim obter a aceitação e respeito dos membros da sociedade em que se circula. Para tanto, conduz a elaboração da face sob um duplo direcionamento: a face defensiva, que orienta a agir defensivamente de modo a salvar a própria face de possíveis ameaças; e a face protetora, que orienta a agir de forma a preservar a face do outro, por meio de valores como respeito, polidez e cortesia. Isto é, o cuidado com a própria face implica também os mesmos cuidados com a face do outro.

Pensemos em situações de possível confronto como dar uma ordem, por exemplo; podemos questionar: o que leva a pessoa a dar uma ordem? Ou mesmo a não optar pela 
ordem? Ou usar estratégias diferentes para ordenar? Sem dúvida, essa pessoa poderá pensar na relação custo-benefício do ato ordenar. Valerá mesmo a pena dar uma ordem? O que é posto em risco? O que se pode ganhar ou se perder em termos de face? Ao proceder dessa forma, a pessoa demonstra estar atenta a sua própria face (imagem pública positiva) e também atenta em não ferir ou ameaçar a face do outro (verificando o contexto, os riscos e os possíveis custos que isso envolveria) para depois não ter atingida sua própria face.

Segundo Goffman, essa preocupação resulta de valores como orgulho, honra e dignidade, elementos mantenedores da face e também da responsabilidade da pessoa perante a si próprio e aos outros. Mas, além desses sentimentos universais, é importante destacar que são as regras e convenções culturais que vão definir o valor dado à face em cada sociedade e explicar, por exemplo, o hábito brasileiro em atenuar pedidos. Sendo a face, portanto, um conceito construído e legitimado de grupo para grupo, parece implicar um compromisso do indivíduo com determinada conduta, como explica Goffman:

\begin{abstract}
Uma vez tendo assumida uma auto-imagem, que se expressa através de uma face, há expectativas e modos que uma pessoa precisa preencher. De diferentes modos, em diferentes sociedades, exigir-se-á que as pessoas demonstrem autorespeito, recusem certas ações por estarem estas acima ou abaixo de si mesmas, ao mesmo tempo em que se forçam para desempenhar outras mesmo que isso lhes custe muito caro. Ao entrar em uma situação na qual lhe é dada uma face a manter, a pessoa toma a si a responsabilidade de patrulhar o fluxo de eventos que passa diante de si (Goffman, 1967, p. 80).
\end{abstract}

\title{
3.2.2
}

\section{Polidez}

De acordo com o senso comum, na cultura ocidental, polidez remete à ideia de bons modos, civilidade, cortesia; equivale a ter ou demonstrar boa educação. Porém, em um enfoque moderno, essa mesma palavra pode, também, ser entendida como um conceito técnico-científico utilizado em estudos pragmáticos e sociolinguísticos para se referir ao conjunto de estratégias linguísticas que podem ser utilizadas por um falante para evitar ou reduzir ao mínimo o conflito com o interlocutor quando os interesses de ambos não coincidem.

Entretanto, definir a palavra "polidez" não é tão simples quanto parece. As descrições de comportamentos e expressões polidas podem se configurar de diferentes formas, pois não são universais, variam de cultura para cultura, de sociedade para sociedade, tornando-se complexo definir quando um comportamento é ou não polido. Por essa razão, Watts (2003, 
p.30-31) diferencia essas duas formas de entender polidez, denominando-as polidez ${ }^{1}$ e polidez $^{2}$. A primeira corresponde à noção do senso comum relacionada a boas maneiras, remetendo a comportamentos sociais específicos de cada cultura, como: cumprimentar alguém com um beijo no rosto ou um abraço, oferecer assento no ônibus para pessoas mais velhas, não falar alto em bibliotecas, etc. Já a segunda acepção corresponde ao comportamento linguístico adotado pelo falante para compensar ou minimizar as ameaças que podem ocorrer na comunicação, com o objetivo de torná-la o menos agressiva possível. Watts (2003) chama ainda atenção para o fato de que esses dois tipos de polidez se sobrepõem, ou seja, algumas expressões que poderiam ser classificadas como realizações da polidez ${ }^{1}$ também podem fazer parte da polidez ${ }^{2}$, como é o caso de expressões formulaicas, que são formas convencionalizadas socialmente, cujo uso já está consolidado e que nos possibilitam agir de forma a evitar conflitos e ameaças à imagem dos interlocutores, tais como: "por favor", "desculpe" ou "obrigada".

Além dessas duas possibilidades de definição, Brown e Levinson (1987), dando sequência aos trabalhos de Goffman, adotam a ideia da preservação da face como principal explicação para o uso de estratégias de polidez na interação comunicativa. Ao compreenderem que a face é, essencialmente, vulnerável, que as interações são eventos potencialmente ameaçadores e que os interactantes da conversação cooperam num jogo em que a preservação da própria face decorre da não agressão à face do outro, formulam seu modelo de polidez, o mais influente e abrangente referencial teórico sobre o assunto.

Para os autores, a face não corresponde a valores ou normas aprovadas pelos membros da sociedade, mas a duas necessidades básicas que todos têm, por isso argumentam que ela apresenta dois lados intrinsecamente relacionados. Assim, propuseram que, em vez de apenas uma face, que requer a aprovação social, qualquer indivíduo possui outra face, que reivindica a limitação de um espaço simbólico, o qual deve ser resguardado na interação. A esses dois tipos de face, Brown e Levinson (1987) chamaram de face positiva e face negativa. A primeira relaciona-se à necessidade de aceitação que os indivíduos têm nas relações sociais, ou seja, o desejo de ser aprovado e aceito pelo(s) parceiro(s) da atividade comunicativa e a segunda, ao desejo que todo o indivíduo tem de não sofrer imposições, de ter liberdade de ação e a individualidade respeitada, estando assim relacionada à reserva de território pessoal.

Atrelada à face positiva e negativa, Brown e Levinson (1987) propõem que há, também, estratégias de polidez positiva, dirigida à face positiva do interlocutor, e de polidez negativa, dirigida à face negativa do interlocutor. Segundo os autores, a primeira é utilizada pelo falante para manter a face positiva do seu ouvinte no intuito de se aproximar deste, a fim 
de obter aceitação e admiração. Nesse sentido, as estratégias de polidez positiva visam diminuir a distância social, envolvendo os participantes da interação de modo mais íntimo. As estratégias de polidez negativa, por sua vez, são utilizadas com o propósito de estabelecer um tratamento mais distante, com o intuito de evitar as imposições e de quaisquer atos de ameaça às faces dos participantes envolvidos na interação. Vejamos, no quadro abaixo, as estratégias propostas por Brown e Levinson (1987):

\section{Estratégias de Polidez Positiva}

1. Perceba o outro. Mostre-se interessado pelos desejos e necessidades do outro.

2. Exagere o interesse, a aprovação e a simpatia pelo outro.

3. Intensifique o interesse pelo outro.

4. Use marcas de identidade de grupo.

5. Procure acordo.

6. Evite desacordo.

7. Pressuponha, declare pontos em comum.

8. Faça piadas.

9. Explicite e pressuponha os

conhecimentos sobre os desejos do outro.

10. Ofereça, prometa.

11. Seja otimista.

12. Inclua o ouvinte na atividade.

13. Dê ou peça razões, explicações.

14. Simule ou explicite reciprocidade.

15. Dê presentes.

\section{Estratégias de Polidez Negativa}

1. Seja convencionalmente indireto.

2. Questione, seja evasivo.

3. Seja pessimista.

4. Minimize a imposição.

5. Mostre respeito.

6. Peça desculpas.

7. Impessoalize o falante e o ouvinte. Evite os pronomes "eu" e "você".

8. Declare os AAF's 8 como uma regra geral.

9. Nominalize.

10. Vá diretamente como se estivesse assumindo o débito, ou como se não estivesse endividando o ouvinte

Quadro 3: Estratégias de polidez propostas por Brown e Levinson (1987)

Para os autores, a polidez exige que se suavize a expressão de qualquer ato de ameaça à face, os quais estão dispostos em proporções variáveis e estão relacionados a três fatores sociológicos: (i) o poder relativo do falante e do ouvinte (poder assimétrico), (ii) a distância social entre o falante e o ouvinte e (iii) o grau de imposição envolvido no ato de ameaça à face / Teor de risco definido culturalmente. Assim, em relação à distância social, Brown e Levinson (1987) dizem que quanto maior for a distância entre os interlocutores, mais suavizadores são necessários. Quanto ao fator poder, em uma relação hierárquica, o princípio de deferência exige que os atos potencialmente ameaçadores se façam acompanhar de uma

\footnotetext{
${ }^{8}$ Atos de Ameaça a Face
} 
“embalagem ritual”, a qual é muito mais importante quando deriva do participante considerado inferior do que quando vem do participante considerado superior.

Segundo os autores, se o risco é baixo, o falante procurará realizar o ato diretamente e de forma transparente "on record". Contudo, se o risco é alto, o falante deve utilizar uma estratégia mais alta, ou seja, sua intenção deve ser percebida pelo destinatário através de uma inferência mais complexa. Assim sendo, o falante deve realizar um AAF de modo OFF "off record".

Brown e Levinson (1987) mencionam que, ao realizar um ato de fala direto, o falante tem as seguintes vantagens: ele pode conseguir pressão pública em favor de si mesmo ou contra o ouvinte; pode ser visto de forma positiva pela honestidade, ao indicar que confia no ouvinte; evita o perigo de ser visto como manipulador; evita o risco de ser mal-entendido. Por outro lado, ao fazer um ato de fala indireto, o falante tem as seguintes vantagens: pode ganhar crédito por ter tido tato, por não ser abusivo; corre menos risco de esse ato entrar na rede de intrigas que os outros mantêm sobre ele; evita responsabilidade sobre a interpretação em potencial da exigência da face; pode conceder ao ouvinte a oportunidade de ser visto se importando com o falante.

Assim, em um contexto marcado por uma recíproca vulnerabilidade de face como na realização dos atos verbais de pedir, qualquer indivíduo tentará evitar atos de ameaça à face, ou fará uso de estratégias para minimizar qualquer tipo de ameaça decorrente desses atos. Segundo os autores, o falante levará em consideração o peso relativo de três intenções, no mínimo: (i) o desejo de manifestar o conteúdo do ato de ameaça à face, (ii) o desejo de ser eficiente e (iii) o desejo de manter a face do ouvinte a qualquer custo. A não ser que (b) seja superior a (c), o falante terá vontade de atenuar a ameaça do seu ato.

A partir destas considerações, vemos a relevância do conceito de indiretividade neste trabalho. Portanto, adotamos como base Blum-Kulka (1987), que aborda a indiretividade e polidez afirmando que um enunciado mais indiretivo tenderia a uma maior polidez, já que aumentaria o nível de opcionalidade, diminuindo a força impositiva do ato. A indiretividade também tem que ser compreendida e sentida pelo ouvinte para alcançar o efeito desejado. Esta pode ser determinada pela forma - seleção de estruturas linguísticas - ou pelo significado seleção semântica. Quando a indiretividade é off-record, isto é, quando o falante deixa sua intenção comunicativa subentendida, o ouvinte tem que deduzir o significado literal da sentença, tentar relacioná-la ao contexto e percebê-lo. Todo esse processo inferencial é mais longo que o de enunciados mais diretos. Dessa forma, uma das formas mais polidas de se 
fazer um pedido ou dar uma ordem seria atuando indiretamente sem sobrecarregar o ouvinte com a exata intenção da indiretividade.

No que tange ao português do Brasil, os atos de fala selecionados pelos falantes nativos são preferencialmente indiretivos, e o estrangeiro situado em nosso território, totalmente desprovido de qualquer intuição linguística que lhe possibilite perceber o tipo de ato social inserido em um enunciado indireto, pode proceder de forma socialmente inadequada (Meyer, 1999). Nesse sentido, Le Berre (2008, p. 31) afirma que formulações de ordens e pedidos explícitos são indesejáveis, sendo, por isso, consideradas grosseiras no português do Brasil. Os pedidos indiretos, por exemplo, são formas preferencialmente empregadas no português do Rio de Janeiro. A autora chama a atenção, ainda, para o fato de utilizarmos entonação de pergunta em formulações de pedidos como estratégia de polidez, substituindo expressões cristalizadas como por favor (Meyer, 1999).

Com esse panorama delineado a respeito da polidez, constatamos que isso só é possível pelo fato de os indivíduos partilharem princípios interacionais embasados em aspectos culturais de uma determinada sociedade. Esses princípios não só nos capacitam a nos comunicarmos como também a realizarmos inferências e a agir de uma forma considerada adequada, de acordo com os contextos situacionais e a conviver com o interlocutor. Consoante as condições que envolvem a polidez, está o seu contrário, a impolidez. Assim, na próxima seção tomaremos conhecimento sobre este termo.

\section{2 .3}

Impolidez

Se a polidez define-se como um meio de minimizar o confronto na interação, a impolidez contraria esse entendimento, sendo o seu oposto. Brown e Levinson (1987), apesar de não tratarem especificamente dessa última noção na Teoria de Polidez, tendem a vê-la simplesmente por essa perspectiva. No entanto, Mills (2003), que se debruçou sobre o assunto, defende que a impolidez exerce uma função bem diferente da polidez na medida em que, além de ser um ato verbal com a clara intenção de ameaçar a face do outro, também parece estar relacionado à demonstração de poder entre os interlocutores envolvidos na interação. É essencial, portanto, examinar os fenômenos envolvidos nos intercâmbios impolidos, já que estes surgem de alguma circunstância interacional. Além disso, torna-se necessário que o ato impolido seja examinado em seu contexto, levando-se em conta todas as 
variáveis (poder, distância, risco) de modo a sabermos o que o motivou e quais seus efeitos sobre os interlocutores.

É relevante ainda considerar que a realização de muitos dos atos impolidos não tem propriamente a intenção de ameaçar a face ou ofender, como alegam Locher e Watts (2005), mas, sim, de exteriorizar alguns sentimentos, como aflição, raiva, ou ainda, uma reclamação (Souza, 2009, p. 6). Além do mais, existem ocasiões em que os falantes não têm qualquer intenção de preservar a face durante a interação e, muitas vezes, nem mesmo a própria imagem. Dessa forma, as provocações e as ofensas são um exemplo de ataque à imagem, que pode levar ao conflito e, até mesmo, a reações físicas violentas.

Em relação aos pedidos, veremos que, em certos contextos, é possível identificar enunciados impolidos, ainda que pareça improvável, pois a chance de o ato ser realizado se torna quase nula; porém como já observado não visam propriamente agredir o interlocutor, mas registrar uma insatisfação que gere uma mudança de comportamento por parte do ouvinte.

\section{3}

\section{O Interculturalismo}

A universalização das relações sociais pressupõe que exista comunicação entre povos, nações, organizações e pessoas de diferentes culturas que coexistem em um mesmo conjunto social. Com isso, manifesta-se a necessidade de estabelecer a defesa das identidades e da pertença étnica. Surge também, a um só tempo, a necessidade de um grupo permitir-se construir relações de reciprocidade com outros. Fleuri (2002, p. 130) declara que:

\footnotetext{
Surge, então, a possibilidade de um movimento cidadão: os diferentes grupos e indivíduos articulam-se sob a forma de redes e parcerias, onde a complementaridade se constrói a partir do respeito às diferenças. Este é o campo das relações interculturais. (grifo nosso)
}

É nessa perspectiva da diversidade e das relações multiculturais que se insere o processo de aprendizagem de um língua estrangeira / língua segunda, próximo ou distante do(s) centro(s) de referência linguístico(s)-cultural(is). Para o estrangeiro, a ideia de um outro lugar é demasiadamente difícil e pautada em uma negociação complexa que não envolve apenas um novo idioma sobre o qual ele ainda tem pouco conhecimento. Mas há muitas 
outras ideias que provavelmente serão ainda mais difíceis de ultrapassar, que é aprender como aprender a se comportar em uma outra cultura, muitas vezes tão distinta da sua.

É nesse espaço de troca, tensão e também de diálogo que emerge a possibilidade de uma vivência intercultural e é, aqui, que se fazem necessários os estudos interculturalistas, que têm como foco sensibilizar o aprendiz para a aceitação da sua cultura e a do outro, a partir da aprendizagem da língua.

Por isso, é preciso reforçar a compreensão de que o português, mais do que língua que se ensina e se aprende, representa a ponte de relações de proximidade, de respeito e de integração (inter) cultural (Mendes, 2011, p.140). Portanto, no campo de ensino de segundas línguas, além da visão estrutural e gramatical no ensino de língua estrangeira, deve-se também trabalhar a língua em contexto, dando possibilidades ao aprendiz de produzir sentenças adequadas, além de aprender a se comportar de acordo com as expectativas daquela sociedade estrangeira na qual está se inserindo, como destaca Meyer (2008) ao citar Singer (1998):

\begin{abstract}
Se eu quero que alguém compreenda a minha mensagem, eu simplesmente preciso traduzi-la para uma linguagem cultural que a outra pessoa compreenda e aceite. Independentemente da mensagem que se quer enviar, se nós quisermos que ela seja recebida favoravelmente, é melhor que nós conheçamos os valores culturais das pessoas com as quais nós queremos nos comunicar e a forma de codificar a mensagem em termos que elas possam compreender. E isso significa chegar a realmente conhecê-los. (Singer 1998, p.142 apud Meyer, 2008) (grifo da autora)
\end{abstract}

Sendo assim, é perceptível que ensinar uma língua estrangeira vai além de ensinar o código, a estrutura de uma língua, ou seja, a Gramática. É transmitir para os aprendizes um conjunto de juízos de valores, de elementos culturais, de comportamentos e crenças que influenciam diretamente na comunicação e nas expectativas interacionais.

\title{
3.3.1
}

\section{Língua e Cultura: um encontro possível}

A “cultura é um conceito com uma embaraçosa gama de definições" (BURKE 2002, p. 165), já dizia o historiador inglês Peter Burke. Defini-la, então, de modo preciso e definitivo parece representar um incrível desafio, visto tratar-se de um termo particularmente polissêmico, que vem evoluindo ao longo do tempo, seja em função dos contextos, seja em 
função do lugar de análise em que o definidor se situa (a Antropologia, a Sociologia, a Filosofia, etc.).

Etimologicamente, cultura deriva do verbo latino colore, que indica cultivar, cuidar, tomar conta, designando o cuidado dispensado ao cultivo da terra e ao gado (Chauí, 2006, p. 245). Enquanto cultivo, a cultura era concebida como uma ação que conduz à plena realização das potencialidades de alguma coisa ou de alguém; seu sentido, portanto, estava relacionado ao fazer brotar, frutificar, florescer.

Entre essa definição e os nossos dias, a ideia de cultura evoluiu significativamente, seguindo diferentes tendências. Mas foi no âmbito da antropologia, segundo Mendes (2015, p. 207), que se produziu um dos conceitos mais rerlevantes de cultura, devido a sua ampla disseminação no pensamento científico e acadêmico:

[...] [A Antropologia] define cultura como um conjunto do estilo de vida de um grupo ou de um povo. São as ideias, os costumes, os sentimentos, as artes, as habilidades, enfim, todas as práticas sociais, que unem as pessoas e as caracterizam como um povo em determinado período do tempo. (Brown, 1994; Montgomery \& Reid- Thomas, 1994).

Esta concepção mais genérica de cultura diz respeito à herança social total da humanidade. Assim, a cultura como um todo compõe-se de grande número de culturas, cada uma com sua maneira própria (semelhante ou diferente da dos outros) de dominar (mais ou menos) a natureza, de organizar as suas relações sociais, de uniformizar (mais ou menos) a personalidade dos seus membros. Esta simples enumeração permite compreender que a cultura engloba não só o que chamamos de estruturas da vida social como também o que chamamos de condutas sociais, isto é, comportamentos e atitudes.

Para efeito deste estudo, adotou-se a ideia de cultura como um sistema de participação, um sistema de práticas, que se baseia na suposição de que "qualquer ação no mundo, incluindo a comunicação verbal, tem uma qualidade inerentemente social, coletiva e participativa” (Duranti, 1997, p. 46). A partir dessa concepção, o falante de qualquer língua é, na realidade, considerado um falante-participante que atua no mundo através do seu falar. Considera-se, assim, a cultura não como algo totalmente externo ao indivíduo (como em rituais ou símbolos), nem como algo totalmente interno (presente na mente do indivíduo); mas, sim, a cultura que existe através das ações rotineiras que incluem as condições materiais - e físicas -, bem como a experiência dos sujeitos sociais e seus movimentos através do contato com os outros seres humanos, outras situações, eventos, atos, crenças e sentimentos. 
Relacionar, portanto, cultura e ensino de línguas é reconhecer a relevância que essa fusão representa diante de uma política de ensino de línguas direcionada para diferentes culturas, viabilizando ao aprendiz uma abertura para o mundo do outro, ao mesmo tempo em que se propõe a afirmar sua própria identidade cultural.

A partir dessa visão, deixa-se de se pensar em cultura como um adorno e passa-se a percebê-la como um patrimônio, ou seja, como um bem de todos; independentemente de nacionalidade, de classe, de língua, ela é realmente uma força vital que move indivíduos e sociedades. E sendo essa força vital não podemos separar cultura de ensino de línguas.

\subsection{2}

\section{Cultura de alto contexto e de baixo contexto}

A dicotomia entre culturas de baixo e alto contexto, estabelecida por Edward Hall (1976), é um conceito intercultural relevante neste trabalho. Em culturas nas quais os elementos contextuais são muito mais importantes para a comunicação, nomeadas culturas de alto contexto, grande parte das informações não está explícita na mensagem, mas no próprio modo de agir do interlocutor. Isto é, os comportamentos não verbais como voz, gestos, postura, linguagem corporal, expressões faciais, etc. são mais relevantes do que os comportamentos verbais. Em contextos como esse, a interação e comunicação devem acontecer de forma mais cautelosa, pois as ambiguidades estão mais presentes.

\footnotetext{
Culturas de alto contexto, tendem a encontrar um significado oculto ou profundo em uma palavra, frase ou situação, considerando não só a palavra falada, mas outras influências periféricas, como o estado ou idade das pessoas envolvidas, do ambiente,do nível social e da linguagem corporal você diz isso, mas os seus olhos querem dizer mais alguma coisa.(Hall 1981:122 apud Gripp, 2011)
}

Já em culturas predominantemente de baixo contexto há uma maior preocupação com os elementos contextuais no processo de comunicação. Nessas sociedades, os indivíduos tendem a ser mais assertivos e utilizam predominantemente a comunicação verbal, isto é, o que é transmitido é descrito explicitamente no código.

\footnotetext{
"Culturas de baixo contexto, tendem a concentrar-se na definição literal de uma palavra ou frase, ou na circunstância literal de uma situação. Estas culturas não dependem de influências periféricas para decifrar uma mensagem e, em vez disso levam a mensagem ao seu valor nominal - isto é o que você disse, então é isso que você quer dizer (Hall, 1981:90 apud Gripp, 2011).
} 
Segundo Silva (2015, p 21), o Brasil é um país caracterizado como uma cultura de alto contexto, pois os brasileiros evitam entrar em choque com seu interlocutor. Desse modo, preferem, durante a interação, usar atos indiretos, pois têm dificuldade de lidar com atos de fala despreferidos como uma ordem, por exemplo, tendo dificuldade de dar ordens de uma maneira impositiva e direta. Associado a isso, podemos destacar que as relações pessoais na cultura brasileira tendem a ser mais íntimas e pessoais, e o contexto interacional veicula a maior parte das informações, sendo, portanto, extremamente difícil lidar com ações que demandam maior imposição. (Como, por exemplo, proferir atos de ordenar, pedir e advertir)

\subsection{3}

\section{Dimensões culturais}

Visando compreender as inter-relações entre cultura nacional e cultura organizacional, o antropólogo holandês Geert Hofstede (2001), no período de 1968 a 1972, realizou um estudo de cunho intercultural em 72 subsidiárias da empresa IBM localizadas em países distintos, aplicando 16 mil questionários em vinte línguas diferentes, a fim de observar a relação entre o trabalho e os padrões de valores de uma diversificada amostra de funcionários. Ao fazer uso de uma amostra equivalente (funcionários de uma mesma organização), a pesquisa conseguiu isolar a variável a ser investigada, ou seja, a cultura nacional. Afinal, para esse autor, os valores disseminados em um ambiente de trabalho são motivados pela cultura nacional e "conhecer as culturas nacionais significa, basicamente, identificar as concepções de vida da sociedade que marcam essas culturas [...]" (Motta, apud Ferrari, 2011a, pp. 146-147). Essa amostra possibilitou, a partir dos dados coletados, situar os participantes da pesquisa ao longo das seis dimensões que descrevem diferentes valores entre as culturas nacionais, as quais foram identificadas por Hofstede, como: Distância do Poder, Individualismo vs. Coletivismo, Masculinidade vs. Feminilidade, Evitação de Incerteza, e Indulgência vs. Controle, conforme resume o quadro a seguir: 
Dimensão cultural

O que diz

\begin{tabular}{c|l}
\hline Distância do & $\begin{array}{l}\text { Medida em que os membros menos poderosos de uma } \\
\text { poder }\end{array}$ \\
& $\begin{array}{l}\text { Sociedade aceitam que o poder seja distribuído desigualmente. } \\
\text { hierarquia estabelecida enquanto sociedades de baixa distância } \\
\text { de poder lutam por relações mais simétricas. }\end{array}$ \\
\hline
\end{tabular}

Masculinidade vs. feminilidade

Sociedades nas quais os valores dominantes são o sucesso e conquistas são consideradas mais masculinas, enquanto sociedades onde os valores dominantes são qualidade de vida e cuidado ao próximo são consideradas mais femininas.

Individualismo

vs. coletivismo
Sociedades onde as pessoas pertencem a grupos familiares, organizações etc. e que cuidam delas em troca de lealdade são mais orientadas para a coletividade enquanto sociedades onde as pessoas cuidam apenas de si mesmas e suas famílias próximas são consideradas mais individualistas.

Medida em que as pessoas se sentem ameaçadas por incertezas e ambiguidades, e tentam evitar tais situações. Sociedades

Controle da incerteza com alto controle de incerteza são mais avessas às mudanças e tentam manter padrões mais rígidos de comportamento, enquanto sociedades com baixo controle de incerteza são mais flexíveis e toleram com maior naturalidade as incertezas.

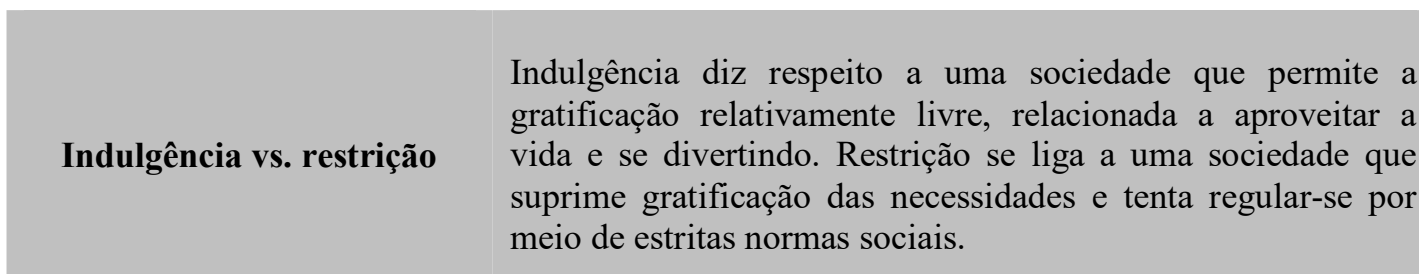

Medida em que as pessoas mostram uma perspectiva orientada para o futuro em vez de um ponto de vista de curto prazo. Sociedades com orientação para o longo prazo valorizam a tenacidade e perseverança, enquanto sociedades orientadas para o curto prazo esperam obter resultados imediatos.

Quadro 4 - Descrição das dimensões da cultura nacional. Fonte: Adaptado de Hofstede (2010).

Antes de prosseguir, é importante pontuar que, apesar da pesquisa de Hofstede focar sua análise no mundo das organizações empresariais, é possível identificar muitas contribuições e diferentes aplicações de sua pesquisa para a área de estudos em que nos situamos, isto é, o ensino de segundas línguas. As categorias criadas pelo antropólogo nos 
ajudam a perceber nossa própria cultura com outro olhar, a partir da observação e análise de certos parâmetros.

Em vista disso, como este trabalho leva em conta características interacionais de ordem, pedido e advertência, optamos por considerar apenas as \caracterizações de cultura Evitação de Incerteza e Individualismo vs. Coletivismo, por acreditarmos que os aspectos abordados na pesquisa de Hofstede (2010) se filiam mais propriamente ao estudo aqui proposto. Assim, a fim de ilustrar as dimensões supracitadas em relação ao Brasil, vejamos abaixo o gráfico com relação às seis dimensões culturais, disponível no site do referido autor:

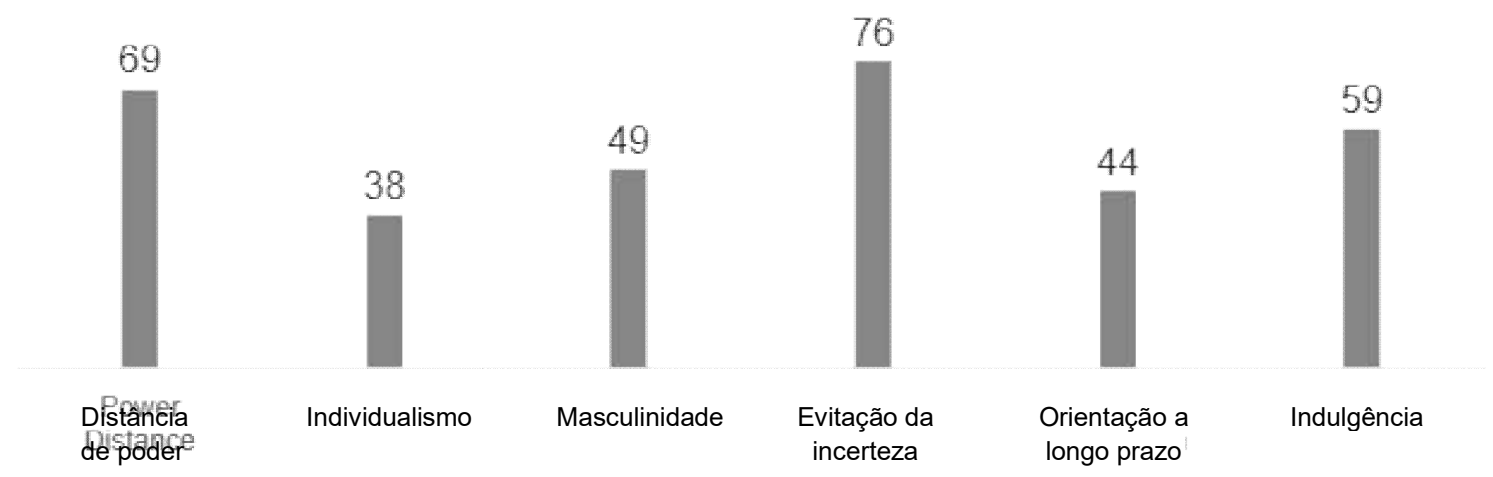

(HOFSTEDE, G. https://www.hofstede-insights.com/country/brazil/. Colhido em 15/05/2019.)

Como podemos verificar no gráfico, com relação à Evitação de incerteza, o Brasil apresenta uma alta pontuação, 76 pontos; Isso demonstra que precisamos de normas e sistemas legais para estruturar a vida: os indivíduos têm necessidade de obedecer às leis. Entretanto, a dificuldade da sociedade brasileira em obedecer tais leis é grande; com isso, criam-se regras adicionais, resultando em uma grande burocracia que visa construir um ambiente mais seguro e com menos incertezas para se viver.

Com relação à dimensão Individualismo vs. Coletivismo, podemos afirmar que o Brasil, com 38 pontos, é uma cultura que tem forte tendência ao coletivismo, que tende a zelar mais pelo nós do que pelo eu, e que protege os membros do seu grupo social em troca de lealdade. Segundo a pesquisa realizada pelo autor, o poder do grupo é predominante na sociedade brasileira. Assim sendo, os interesses coletivos estão acima dos individuais, o que explica a predisposição dos brasileiros em manter a harmonia e evitar confrontos diretos.

A partir da descrição das dimensões culturais de Hofstede (2010), podemos comprovar que membros de determinado grupo identitário compartilham traços comuns que os 
distinguem de outros grupos, e essa semelhança também se reflete na língua de interação utilizada por esse grupo, elemento essencial na construção da identidade cultural dos grupos sociais, como bem ilustra Meyer (2013):

[...] Como o modelo de Hofstede permite perceber [...], a construção da identidade cultural de qualquer grupo social está vinculada, entre outros fatores, mas de forma muito especial, ao uso da língua de interação desse grupo e a imagens sociais construídas verbal e não verbalmente. (Meyer, 2013, p. 21)

Dessa forma, é imperativo realçar a importância de estudos interculturais que buscam reconhecer traços culturais que viabilizem e afirmem a heterogeneidade entre diversas culturas. Logo, o estudo das dimensões culturais é de grande importância para este estudo, uma vez que pode cooperar para o embasamento necessário à análise do elemento cultural expresso linguisticamente nas placas e cartazes presentes em diferentes espaços da sociedade brasileira. Assim, objetivamos investigar o modo como as dimensões escolhidas, neste trabalho, são realizadas linguisticamente pelos interlocutores.

\section{4}

\section{Conceitos da Antropologia Social}

Uma vez que a construção de enunciados de pedido implica também aspectos da cultura subjetiva, podemos encontrar dentro da Antropologia Social conceitos úteis para compreender a interface estabelecida entre o comportamento não-linguístico e as situações de uso real do português brasileiro.

Nesta seção, abordaremos os conceitos binários casa e rua, e indivíduo e pessoa, dicotomias fundamentais para o entendimento do estudo delineado.

\subsection{1}

\section{A Casa e a Rua}

É através da sociabilidade construída cotidianamente que os diversos atores sociais vivem e convivem com seus iguais, participando em conjunto de várias atividades. E é assim que DaMatta (1997) adota a ideia de sociedade não como um agrupamento de indivíduos, mas como entidade, “ [...] que se faz e refaz por meio de um sistema complexo de relações sociais [...] (p.13). A partir dessa consideração, o autor vale-se de duas categorias sociológicas, a casa 
e a rua, dois universos sociais distintos, “[...] fundamentais para compreensão da sociedade brasileira de uma maneira globalizada (Idem, p.14).

Segundo DaMatta (1997), nossa sociedade orienta as suas ações por meio desses dois códigos sociais que, apesar de diferentes, se complementam. Para ele, "casa e a rua são mais que locais físicos. São também espaços de onde se pode julgar, classificar, medir, avaliar e decidir sobre ações, pessoas, relações e moralidades" (1986, p. 23). O espaço da casa seria, portanto, norteado por uma ética conservadora, referindo-se ao lugar simbólico do sagrado e da moral, dos laços de sangue, da intimidade e, consequentemente, de menor distância social. É também o espaço privado, onde se faz o que quer, pois, afinal de contas, é "seu". A rua, por sua vez, é o lugar que se baseia em convicções mais liberais, retratando o espaço simbólico da desordem e do profano, do anonimato, das leis e da transgressão. Nela, todos são iguais e não se abrem exceções para as particularidades. As relações são mais duras, secas, distantes e geralmente rápidas. "Na rua não há amor, consideração, respeito ou amizade", diz DaMatta (2003, p. 15).

Ao apontar essa relação de oposição entre casa e rua, o autor (1997, p. 54) dá voz a estes simbolismos por meio de expressões cotidianas que acompanham o povo brasileiro. Expressões do tipo "estar em casa" e "sentir-se em casa" denotam familiaridade, hospitalidade e senso de pertencimento a um grupo. Por outro lado, a rua parece ser o local eleito da exclusão, da solidão e da falta de pertencimento e vínculo. Expressões como "vá para o olho da rua", "ser posto para fora de casa" e "estou na rua da amargura" ilustram esses significados atribuídos, por nós, à rua.

Nessa perspectiva, casa e rua representam, para nós, sistemas diferenciados que nos ajudam a classificar e a ordenar nosso comportamento. Entretanto, apesar de parecem espaços imutáveis, estes dois ambientes sociológicos representam mundos complementares e compensatórios. Há situações em que o espaço da rua pode ser visto e manipulado como se fosse um prolongamento ou parte da casa, enquanto o espaço da casa pode ser percebido, em determinadas situações como parte da rua.

Podemos sugerir que existem situações na casa que se prolonga na rua e na cidade, de tal modo que o mundo social é centralizado pela metáfora doméstica. Por outro lado, teríamos situações inversas quando a rua e seus valores tendem a penetrar no mundo privado das residências, com o mundo da casa sendo integrado pela metáfora da vida pública. E teríamos ainda situações onde os dois mundos se relacionam por meio de uma 'dupla metáfora', com o doméstico invadindo o público e, por sua vez, sendo por ele invadido. (DaMatta, 1997, pp. 101-102). 
Entretanto, essa relação entre a casa e a rua, ou o público e o privado, se dá de forma contraditória. Na sociedade brasileira é comum uma mudança de atitude ou opinião, dependendo do contexto ou das circunstâncias em relação a esses espaços. Enquanto em casa todos costumam se sentir supercidadãos - lugar onde se podem fazer coisas até mesmo condenadas no espaço público - na rua, onde passamos sempre por indivíduos anônimos e desgarrados, nos sentimos subcidadãos, o que explica o comportamento extremamente inadequado em relação às coisas públicas. Segundo DaMatta:

Jogamos o lixo para fora de nossa calçada, portas e janelas; não obedecemos às regras de trânsito, somos até mesmo capazes de depredar a coisa comum, utilizando aquele célebre e não analisado argumento segundo o qual tudo o que fica fora de nossa casa 'é um problema do governo!' Na rua a vergonha da desordem não é mais nossa, mas do Estado. Limpamos ritualmente a casa e sujamos a rua sem cerimônia ou pejo. (DaMatta, 1997, p. 12)

A análise de DaMatta revela que não há coerência na conduta do brasileiro. Há uma cidadania em casa e outra na rua, sendo esta última, a mais negativa. Nela, nos constituímos em indivíduos livres, e muitas vezes descomprometidos com os interesses coletivos e alheios à conservação do patrimônio público, uma vez que parecem pouco enraizadas na sociedade brasileira as noções de patriotismo e de senso de cidadania, as quais pressupõem atenção não apenas com os interesses individuais, mas também coletivos. Como bem lembrou DaMatta, a relação entre o público e o privado no Brasil é, ao mesmo tempo, de oposição e de complementaridade. Por isso, o autor afirma que a característica da sociedade brasileira está justamente no elo, na conexão, na ponte que liga a casa e a rua.

Nesses domínios, as relações sociais são ordenadas por diferentes valores. Entre eles estão as categorias pessoa e indivíduo - conceitos amplamente utilizados na pesquisa antropológica - os quais agregam valores associados respectivamente à casa e à rua.

\section{4 .2}

\section{Indivíduo e pessoa}

Segundo DaMatta, é básica, na sociedade brasileira, a distinção entre a pessoa e o indivíduo como duas formas de conceber o universo social e nele agir (DaMatta, 1997, p. 219). Se, por um lado, "a pessoa merece solidariedade e um tratamento diferencial", por outro o indivíduo "é o sujeito da lei, foco abstrato para quem as regras e a repressão foram feitas". Sendo assim, os sujeitos da rua são os indivíduos, aqueles seres anônimos a quem as leis 
impessoais conferem a mesma dignidade, isto é, o mesmo valor moral; os sujeitos da casa, por sua vez, são as pessoas, aquelas que têm o poder de transpor a lei, são assim reconhecidas pelos laços de parentesco, amizade, lealdade, etc. - isto é, pelas relações hierárquicas - que são mantidas entre si.

As características que distinguem as noções de indivíduo e pessoa podem ser assim apresentadas, segundo DaMatta (1997, pp. 225-226):

\begin{tabular}{cc}
\hline Indivíduo & Pessoa \\
\hline Livre, tem direito a um espaço próprio. & $\begin{array}{c}\text { Presa à totalidade social à qual se vincula } \\
\text { de modo necessário. }\end{array}$
\end{tabular}

Igual a todos os outros.

Complementar aos outros.

Tem escolhas, que são vistas como seus Não tem escolhas. direitos fundamentais.

A consciência é individual.

A consciência é social (isto é, a totalidade tem precedência).
A amizade é básica no relacionamento = escolhas.
A amizade é residual e juridicamente definida.

O romance e a novela íntima, individualista (obra de autor), são essenciais.
A mitologia, as formulações paradigmáticas do mundo são básicas como formas de expressão.
Faz as regras do mundo onde vive

Não há mediação entre ele e o todo.
Recebe as regras do mundo onde vive.

A segmentação é a norma.

Quadro 5 - Fonte: DaMatta (1997)

A partir dessas categorias, DaMatta reconhece que o Brasil baseia suas relações de forma um tanto ou quanto peculiar. Não seria tão pessoalista como na Índia, mas também não 
seria tão impessoalista como nos Estados Unidos. No cotidiano brasileiro, segundo o autor, haveria um meio termo, ou seja,

[...] o Brasil fica situado a meio caminho: entre a hierarquia e a igualdade; entre a individualização que governa o mundo igualitário dos mercados e dos capitais e o código das moralidades pessoais, sempre repleto de nuanças, gradações e marcado não mais pela padronização e pelas dicotomias secas do preto e do branco, de quem está dentro ou fora, do é ou do não é, mas permitindo mais uma diferença e uma tonalidade. De fato, a sugestão é a de que, no Brasil, temos os dois sistemas A operando numa relação de reflexividade de um em relação ao outro, de modo que sempre confundimos mudar com oscilar de um lado para o outro (DaMatta, 1997, p. 246).

O que se percebe, então, é uma sociedade profundamente marcada pela ambiguidade. Nela, os códigos de valores e os sistemas de referência convivem em um só lugar. A passagem e a transição entre eles é algo tão natural que permite criar uma multiplicidade de possibilidades de relações em todas as áreas de interação humana.

Para DaMatta (1997), essa flutuação ocorre devido ao caráter conciliatório do brasileiro que se dá quando ele encontra, no mundo da rua, o mundo da casa; quando ele escolhe ser pessoa onde normalmente se é indivíduo. É desse modo que ele consegue evitar a incerteza. A igualdade das ruas é uma aventura, por isso, pode ser mais seguro permanecer e estabelecer relações conforme acontecem no mundo da casa. E é assim que presencia-se, na sociedade brasileira, mais a categoria pessoa do que a categoria indivíduo. 


\section{Aspectos Metodológicos}

O presente capítulo tem por objetivo apresentar a metodologia empregada na análise dos avisos não oficiais veiculados em placas e cartazes. Inicialmente, são fornecidas informações acerca da natureza da pesquisa e dos dados. Em seguida, apresentamos a organização do corpus e os procedimentos de análise dos materiais reunidos.

\section{1}

\section{A natureza da pesquisa}

Com o propósito de melhor analisar os enunciados de pedidos, que possuem a finalidade de advertir, informar e/ou conscientizar seu leitor/interlocutor, esta dissertação consiste em uma pesquisa de base qualitativa, que busca uma visão ampla e abrangente dos fenômenos aqui estudados, e tem, principalmente, a preocupação com o contexto cultural e linguístico em que se encontra o aprendiz estrangeiro.

Uma análise qualitativa mostra-se mais apropriada, pois segundo Gibbs (2009, p. 17),

[...] os dados qualitativos são essencialmente significativos, mas mais do que isso, mostram grande diversidade. Eles não incluem contagens e medidas, mas sim praticamente qualquer forma de comunicação humana - escrita, auditiva ou visual; por comportamento, simbolismos ou artefatos culturais.

Tendo em vista que os dados a serem analisados são predominantemente extraídos de práticas sociais cotidianas, manifestas em diversos espaços coletivos da sociedade, a metodologia de natureza qualitativa atende plenamente aos objetivos deste trabalho, uma vez que "a maior força da pesquisa qualitativa é sua capacidade para analisar o que de fato acontece em ambientes que ocorrem naturalmente" (Silverman, 2009, p. 312).

\section{2}

\section{A natureza dos dados}

O corpus da pesquisa constitui-se de avisos não oficiais, especialmente aqueles veiculados em placas e cartazes presentes em diversos ambientes sociais, públicos ou privados, do território brasileiro. Todos são relativos a questões de procedimento social e têm 
como propósito levar o interlocutor a agir de acordo com padrões socialmente aceitos, podendo envolver avisos de orientação em banheiros, ambientes corporativos, ruas, estabelecimentos comerciais, etc. Os dados foram selecionados a partir de acervo particular de imagens, registradas em fotografias, e também da seleção das imagens de diferentes páginas sociais acessadas por meio de pesquisas realizadas no Google.

A escolha de avisos em placas e cartazes não oficiais se deve ao fato de os enunciados desses suportes possuírem uma linguagem mais próxima da realidade, em um estilo menos monitorado e mais informal, o que facilita o reconhecimento dos falares cotidianos do português brasileiro, para a aplicabilidade em um ensino que leve em conta principalmente os contextos reais de uso.

\section{3}

\section{Organização do corpus e procedimentos de análise}

Quanto à organização do corpus, primeiramente, foi realizado um levantamento geral dos avisos em placas e cartazes não oficiais, de setembro de 2017 a junho de 2018. Todos foram salvos em formato de imagem e se apresentam, neste trabalho, conforme estavam afixados nos locais em que foram identificados, assim são dados originais, sem qualquer tipo de alteração em relação à ortografia, à pontuação e à sintaxe. Após essa etapa, os dados encontrados foram agrupados sob seis divisões de grupos temáticos, de acordo o local onde estavam afixadas as mensagens: banheiros, estabelecimentos comerciais, ruas, praças e jardins, condomínios residenciais e transportes públicos.

Quanto aos procedimentos de análise, é importante ressaltar que, devido à natureza dos dados, adotamos uma análise fundamentalmente de base qualitativa e descritiva, buscando interpretar de modo crítico-reflexivo o fenômeno estudado a partir das diferentes realizações linguísticas de pedidos.

Desse modo, para proceder à análise de dados, foram selecionados 32 (trinta e dois) avisos dos agrupamentos temáticos correspondentes às variadas situações comunicativas citadas anteriormente. As placas e cartazes analisados serão identificados pela sigla E, que significa exemplo, seguido de numeração sequencial (E1, E2, E3, e assim sucessivamente).

Os atos de fala de pedidos enunciados nesses avisos foram distribuídos em 6 (seis) categorias semântico-pragmáticas levando-se em conta tanto a composição da mensagem quanto o conteúdo semântico construído a partir da situação-contexto em que estão inseridas 
as placas e cartazes não oficiais, sendo elas: ameaça, agressividade, apelo, ironia, cordialidade e disciplina.

Após a identificação dessas categorias, procede-se a uma análise de conteúdo com vistas a identificar mais facilmente os fragmentos de brasilidade que se fazem presentes nesses avisos, cujos textos valem-se de conhecimentos de mundo para alcançar os efeitos almejados, e que, por isso, podem ser interpretados de maneira equivocada por estrangeiros, já que leva-se em conta o sentido literal do enunciado elaborado.

Vale ressaltar que o foco deste trabalho recai sobre a análise das estruturas linguísticas utilizadas pelos falantes na produção dos atos diretivos. Portanto, os aspectos prosódicos e não verbais não foram priorizados neste estudo. No entanto, consideramos importante, ainda que sucintamente, tecer alguns comentários sobre as imagens que compõem alguns dos avisos apresentados, visto que tais elementos fornecem relevantes subsídios para uma análise mais detalhada e aprofundada das mensagens que se deseja comunicar aos interlocutores, constituindo-se em expressivos itens de reforço. Desse modo, as imagens serão apenas comentadas quando se tornarem elementos importantes para a análise geral dos avisos e placas nos atos. Sendo assim, não serão feitos levantamentos e classificações minuciosas das mesmas. 
5

\section{Análise dos dados}

A análise de dados aqui apresentada será realizada, como já mencionado anteriormente, à luz das categorias semânticas identificadas em nosso corpus, a saber: ameaça, agressividade, apelo, cordialidade, disciplina, ironia.

Em cada uma dessas categorias será observado como se constituem os tipos de pedidos encontrados em placas e cartazes não oficiais e as estratégias utilizadas pelos interactantes para realizá-los. Além disso, também será feita uma análise interpretativa dos dados estabelecendo um cruzamento entre os fatores contextuais e culturais.

Assim, para uma melhor organização e clareza, primeiro, serão expostas as categorias semânticas, acompanhadas de suas respectivas definições, as quais foram feitas a partir de informações dicionarizadas para auxiliar o leitor na compreensão mais ampla da categoria. Em seguida, apresentamos as imagens dos pedidos selecionados e, logo depois, a análise interpretativa dos enunciados veiculados em placas e cartazes em diferentes situações sociais.

Vale destacar que consideraremos em nossa análise aqueles enunciados que julgamos mais relevantes para que possamos indicar as estratégias a serem abordadas em contextos de aprendizagem de PL2E. Deste modo, com base na fundamentação teórica, procedemos com a análise dos dados, discorrendo sobre cada categoria encontrada. 


\section{1}

\section{Ameaça}

Segundo o dicionário da língua portuguesa Aurélio (2001:38), Ameaça é, por definição, uma "promessa de castigo ou malefício", um "prenúncio ou indício de coisa má", podendo ser ainda definida como "palavra ou gesto intimidativo".

Assim sendo, é um ato socialmente reprovado, pois tem por consequência principal, geralmente, o estremecimento das relações entre os interlocutores.

Como se sabe, no português do Brasil, a realização de pedidos dessa natureza vai na contramão da essência social do povo brasileiro tido, em geral, como amigável, conciliador e avesso a enfrentamentos com seu interlocutor. No entanto, no que diz respeito à linguagem, não é possível afirmar que o comportamento linguístico do brasileiro sempre será manifestado e compreendido como foi descrito por Holanda (1995), porque as escolhas discursivas/linguísticas e seu uso se submetem às características de cada situação comunicativa.

Vejamos a seguir como os enunciadores optaram por elaborar os pedidos em tal conjuntura:

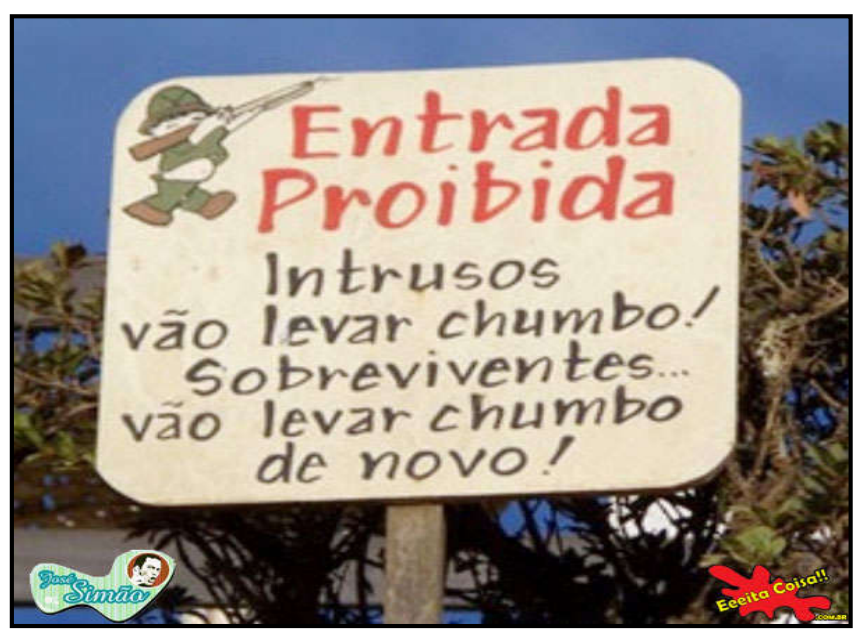

E1 $^{9}$

\footnotetext{
${ }^{9}$ As fontes dos avisos apresentados na análise de dados encontram-se nos Anexos.
} 


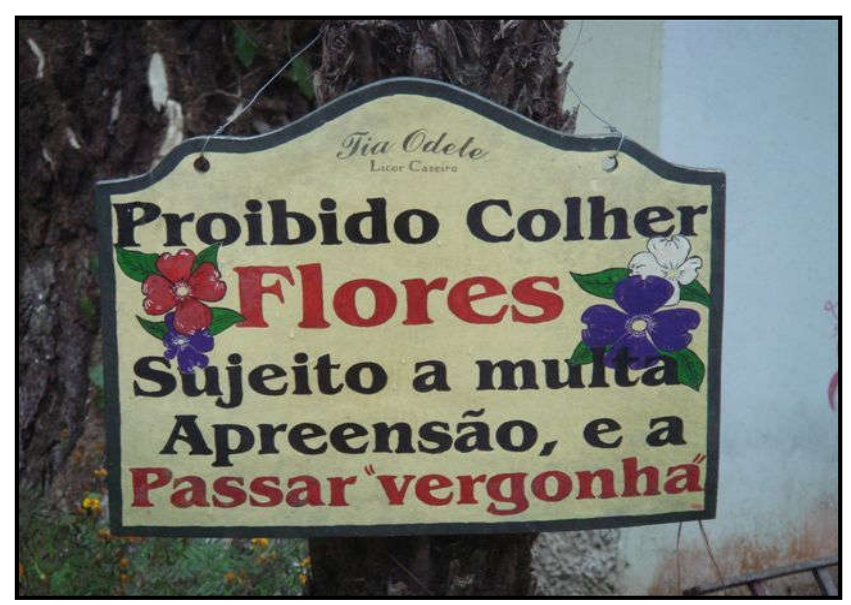

E2

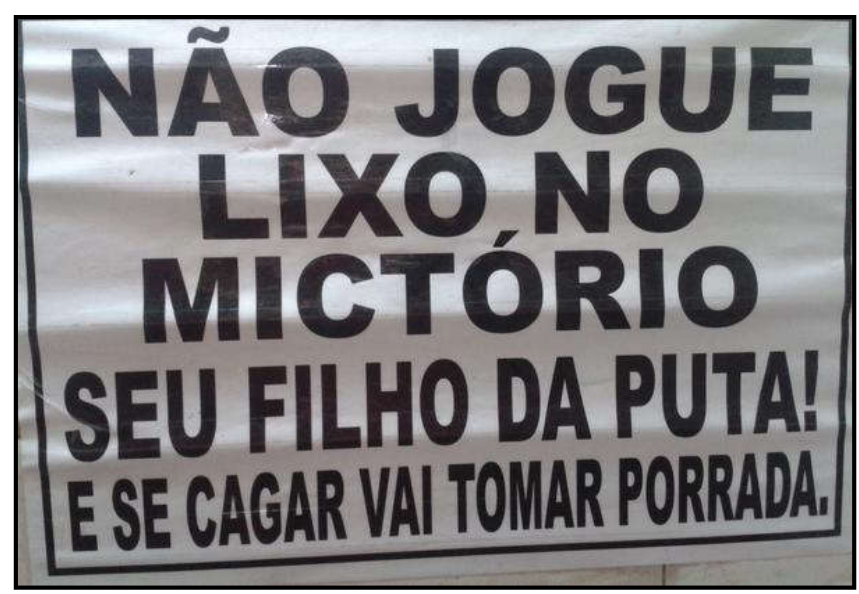

E3

A partir da análise das amostras referentes à categoria ameaça, constatamos que os pedidos apresentados acima denotam, segundo Blum-Kulka e Olshtain (1984), o tipo de estratégia modo derivável (estratégia 1), considerado o mais direto. Pelos atos de fala, podemos verificar que os solicitantes iniciam com atos principais objetivos, geralmente utilizados em avisos de proibição. Nestes casos, a perspectiva do pedido está orientada para locutor (eu).

Destarte, constatamos em E1 que o solicitante opta, inicialmente, por utilizar como estratégia discursiva no ato principal, de acordo com Blum-Kulka e Olshtain (1984), uma expressão muito empregada em avisos colocados em propriedades particulares. A mensagem é curta, direta, e realizada com a expressão "Entrada proibida", que restringe, neste primeiro momento, um embate ameaçador entre os interlocutores, pois lança mão de um conhecimento 
partilhado. Consideramos que este tipo de aviso restritivo não demanda maiores implicações por caracterizar-se como comum, logo, passaria despercebido.

É sabido, no entanto, que os brasileiros tendem a ser prolixos e a expressar naturalmente suas emoções, sejam elas de satisfação ou descontentamento. O seu dizer contém mais informação do que teoricamente necessitaria, ou seja, parece haver na fala do brasileiro uma necessidade de falar mais, em vez de apenas comunicar o necessário. Assim, o que deveria ser um simples aviso ganha novo sentido com a presença do ato de apoio (BlumKulka e Olshtain, 1984). O uso do substantivo “intrusos” demarca já de início o grupo a quem o solicitante se direciona, causando um efeito de distanciamento existente entre eles, uma vez que coloca os interlocutores como pertencentes ao grupo que reflete uma forma de perigo. $\mathrm{O}$ pedido soa, então, como de interesse pessoal, ou seja, exprime o desejo do locutor em proteger o seu bem material.

Para tanto, a fim de sintetizar ou definir toda uma situação, o solicitante utiliza a expressão idiomática "levar chumbo" para manifestar explicitamente a sua ameaça e tentar garantir o cumprimento do pedido. O uso da construção nesse contexto prevê o leitor como aquele que possui o conhecimento sobre essa expressão de forma cristalizada a ponto de produzir sentido para quem a lê. Desse modo, um falante nativo do português brasileiro lerá facilmente que caso alguém não obedeça ao comunicado da placa, poderá sofrer algum tipo de violência ou ser atingido por tiro.

É preciso atentar, porém, para o fato de que essa expressão típica do discurso nacional brasileiro reflete um conhecimento compartilhado que pode não ser compreensível para um estrangeiro, mesmo que o contexto sinalize o seu sentido ou ainda tenha recursos imagéticos que permitam inferir a mensagem veiculada. Devido a isso, o estudo lexical se configura, durante o trabalho do professor de PL2E, como uma atividade de fundamental importância para a proficiência linguística do aprendiz, pois permite o domínio efetivo de expressões linguísticas em situações de uso recorrentes da língua alvo.

No contexto enunciativo (E2), percebemos, também, a opção do solicitante em introduzir o pedido a partir de uma construção que isoladamente serviria para realizar o ato independentemente de outros elementos.

A escolha do enunciado impessoal "Proibido colher flores" para introduzir o pedido parece indicar, a princípio, que o solicitante não deseja impor-se sobre o seu interlocutor, pois recorre a uma construção constituída por um agente neutro que carece de referência específica. 
Porém, esta estratégia só permite uma aparente manutenção da harmonia discursiva, a sequência de ameaças realizada de forma direta no ato de apoio - "Sujeito a multa, Apreensão, e a Passar "vergonha"" - revela um outro enunciador, aquele que não está disposto a negociações e que, se for preciso, recorrerá a instâncias oficias para manter a ordem, aplicando medidas educativas como a "multa" e a "apreensão". Mas, sobretudo, agirá também por conta própria, fazendo o interlocutor "passar vergonha". Como podemos ver na ilustração, essa medida está em destaque. As letras estão em vermelho e a palavra "vergonha" entre aspas. O solicitante com isso parece querer comunicar algo a mais, podendo transmitir a ideia de ser essa a atitude mais desconcertante, justamente por ter dimensões desconhecidas para o interlocutor.

Segundo Brown e Levinson (1987), um ato realizado de maneira direta normalmente realiza-se desse modo se o enunciador não temer uma retribuição do leitor/ouvinte. É comum esse tipo de ato ocorrer em algumas circunstâncias, como por exemplo, em ocasiões em que o locutor percebe que o trabalho de face deve ser colocado em segundo plano em favor da urgência e necessidade do cumprimento daquilo que é solicitado. Os autores ainda acrescentam que, se o risco de um ato de ameaça à face (AAF) é baixo, o enunciador tende a realizá-lo diretamente e de maneira transparente "on Record". Nos exemplos acima, percebemos que a urgência de ações adequadas é fator que influencia na escolha do pedido direto.

Tendo em vista ainda a análise dos pedidos ameaçadores, encontramos em E3, além das características de E1 e E2, um pedido constituído pelo verbo jogar no imperativo negativo (jogue). Em sua escala de diretividade dos atos diretivos, Blum-Kulka (1984) considera esse modo verbal como a forma mais direta e explícita para se fazer pedidos, e também a menos polida. Logo, o solicitante, por meio dessa estratégia de explicitação de poder, que provém da sua condição de proprietário do banheiro, nega a autonomia dos interlocutores de agir como desejam e exercita um tipo de coerção para que o ato pretendido seja atendido.

Nesse contexto em que a vulnerabilidade da face se mostra desigual, podemos observar que a motivação para o solicitante ser cooperativo e flexível é reduzida. Além do mais, parece-nos que, em situações nas quais há grande aborrecimento e prejuízo, o comportamento impolido por parte de quem sofre a ação tem mais chance de ocorrer. Como pode ser visto em E3, o solicitante avalia o seu interlocutor de modo negativo, pelo uso da forma de baixo calão "seu filho da puta!", termo pejorativo que retrata a pessoa como não sendo confiável, segundo Houaiss \& Villar (2009). Essa avaliação negativa é intensificada no 
próprio endereçamento por meio do pronome possessivo seu, que junto ao vocativo expressa uma provocação (NEVES, 2000: 471-490).

Essa perspectiva também é identificada no ato de apoio "E se cagar vai tomar porrada". O uso da palavra cagar (maneira grosseira de dizer defecar, no português brasileiro) e "vai tomar porrada" (ato de receber golpe muito violento; pancada, tapa) deixam transparecer o sentimento de raiva do locutor, que, motivada em um momento anterior, perdura até o presente. Conforme diz Kerbrat-Orecchioni (2006), a função dos agravantes é, justamente, a de reforçar o ato de fala e de aumentar o seu impacto, em vez de abrandá-lo e atenuá-lo (Kerbrat-Orecchioni, 2006, pp. 90-91). A ameaça apresentada no ato, portanto, é uma constante, um constrangimento até aos não praticantes do ato censurado.

É importante frisar que, apesar de o palavrão e as palavras de baixo calão serem considerados como obscenos, grosseiros, ofensivos ou agressivos, há de se reconhecer o seu lugar também no ensino de línguas para o desenvolvimento da competência intercultural. Acreditamos que, apesar de esse ser um assunto polêmico, não se pode desprezar esse conjunto de itens lexicais tão utilizados pelos brasileiros em seu cotidiano visto que, diante de tantos contextos a que os aprendentes de PL2E estão expostos, muitos podem incorporá-los ao léxico cultural apreendido sem saber do que se tratam. Parece-nos conveniente ao professor trabalhar uma pedagogia que aborde essas expressões, inserindo estratégias que levem o aluno à reflexão, esclarecendo que existem diferenças linguísticas e que elas podem ser utilizadas, conforme salienta Bagno, "no lugar certo, no contexto adequado, com as pessoas certas (...)" (2007, pp. 129 - 30).

\section{Indiretos}

Tratando-se dos exemplos indiretos dessa categoria, notamos que a presença da ameaça permanece, porém sob outra configuração. Vejamos a seguir as amostras selecionadas: 


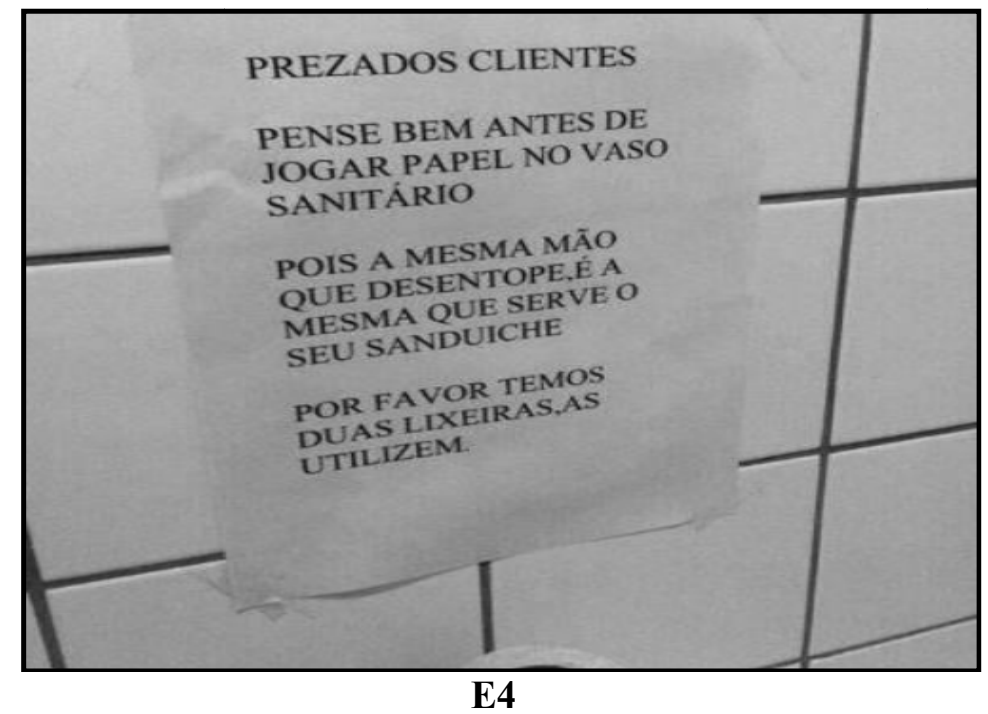

U్ర

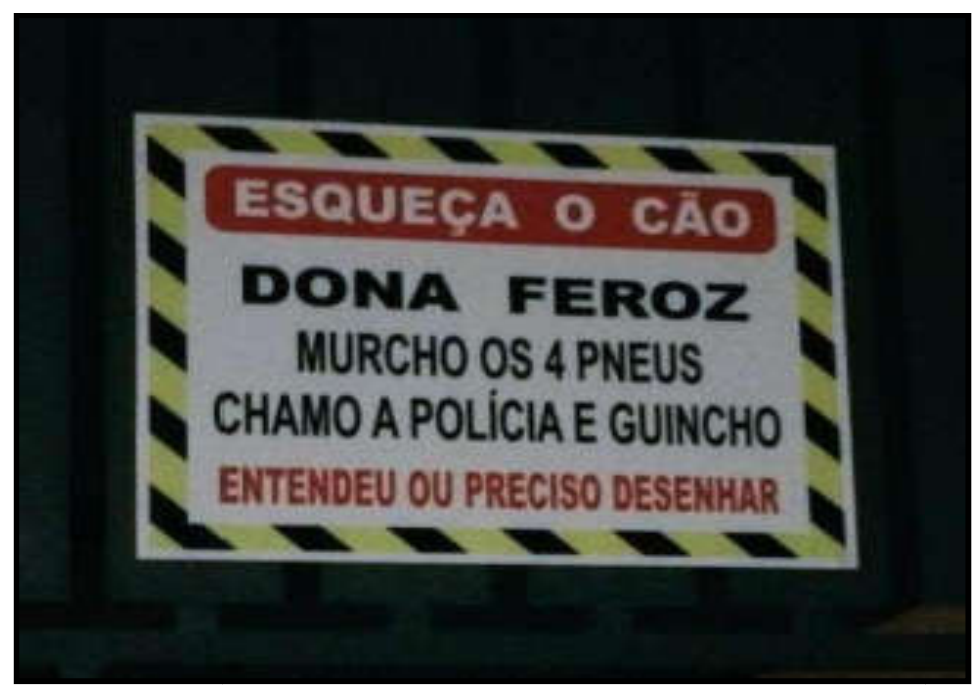

E5

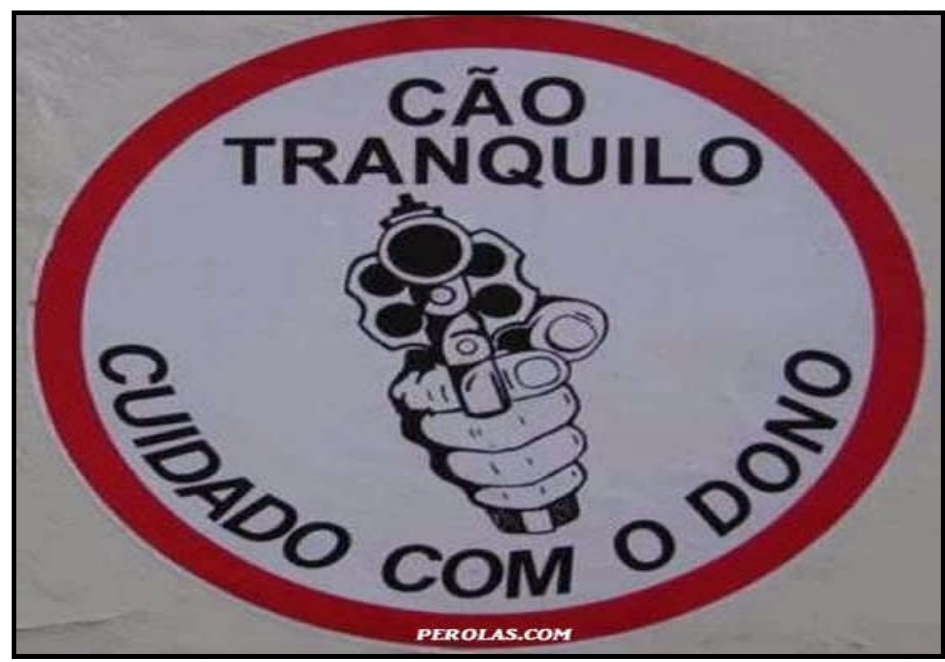

E6 
Além de esses pedidos serem classificados como diretivos indiretos - conforme a taxonomia de Searle (2002) - esses atos de fala são classificados como indiretos nãoconvencionais de acordo com Blum-Kulka e Olshtain (1984) e Brown \& Levinson (1987), pois o solicitante não diz ao interlocutor o que deve fazer propriamente apenas o comunica sobre um fato e deixa que este conclua sobre o que deve ser feito.

Ao analisarmos o pedido em E4, vemos que o solicitante inicia o ato de fala com um endereçamento: a forma de tratamento "Prezados clientes". Ao empregar esse recurso, o locutor tenta estabelecer um contato polido e ao mesmo tempo chamar atenção para o que vai anunciar no ato principal. A escolha da expressão de tratamento formalizada reflete uma grande distância social entre o falante e o destinatário da interação.

Seguindo essa tendência respeitosa, no ato principal, o solicitante procura fazer a dissimulação das reais intenções do seu pedido pelo uso de uma forma rotineira de conselho: "Pense bem antes de jogar papel no vaso sanitário". Consideramos que existe no enunciado um sentido a mais que encobre a verdadeira intenção do falante. Isto é, ele não espera que o usuário do banheiro pense, reflita em algo antes de jogar o papel no vaso sanitário; mas, de fato, o que ele deseja é que este jogue o papel na lixeira.

Para tal, é comum os solicitantes realizarem o ato de fala indireto por meio de pistas que consistem em sugerir o ato desejado como, por exemplo, dizer o motivo ou a razão para fazer algo (Brown e Levinson, 1987). O solicitante comunica ao destinatário mais do que ele realmente diz ou declara algo diferente do que pretende que seja entendido. Neste caso, cabe ao destinatário inferir a mensagem. As inferências é que vão recuperar aquilo que o enunciador realmente pretende comunicar.

Nessa perspectiva, o solicitante vale-se da ameaça no ato de apoio, introduzido pela conjunção explicativa pois, e conduz o leitor para uma espécie de justificação do que foi dito na primeira proposição. A mensagem nele contida pode parecer clara para falantes nativos do PB que, enquanto participantes do mesmo jogo de linguagem, estão familiarizados com os hábitos e práticas um do outro; porém para um falante estrangeiro é precisa a realização de uma inferência mais complexa e explícita, para que ele possa compreender que o que está por de trás do enunciado é uma ameaça, revestida de um poder que o próprio falante se atribuiu para oprimir o interlocutor e, assim, fazer cumprir seu ato.

Notamos, ainda, precedente ao ato de apoio final, o uso da expressão "por favor", tradicionalmente considerada como um marcador de polidez, mas que pode também apresentar outras funções, tais como: expressar desagrado, desaprovação e impaciência com 
seu interlocutor (Bernal, 2006 apud Dias, 2010). Aqui consideramos uma maior proximidade com esses valores, visto que o enunciador não parece ter a intenção de minimizar os efeitos do FTA (Ato ameaçador da face).

Analisando o exemplo E5, identificamos outra estrutura de pedido indireto ameaçador. Nesta ocorrência temos um ato de apoio explicitando uma ordem sob forma de título ("Esqueça o cão"), seguida do alerta de identificação do solicitante do pedido ("Dona feroz"), dos atos principais ("Murcho os 4 pneus"; "Chamo a polícia") e do ato de apoio ("Entendeu ou preciso desenhar").

Inicialmente, a solicitante explicita uma ordem: "Esqueça o cão". O verbo esquecer na forma imperativa elimina a ideia de que somente o cão é o responsável por inibir ações inadequadas, ou seja, sugere que há outras formas para isso. Para tal, já de início confere ao pedido uma pista forte, legitimando a sua postura impositiva. A locutora usa de um conhecimento compartilhado para enfatizar, na verdade, a sua ação individual como sendo muito mais eficaz do que o animal.

Em seguida, vemos que, ao se auto-identificar como Dona feroz, a solicitante expressa a sua insatisfação com a situação experienciada e, indiretamente, com o comportamento do suposto interlocutor. Essa designação transparece uma tensão e contribui para aumentar o grau de imposição da solicitação. Diante da situação, o enunciador demonstra não estar nem um pouco preocupado com os desejos da face negativa do interlocutor da mensagem e nem com a sua própria face positiva; o seu desejo de ser aprovado e apreciado é posto em risco em favor do cumprimento ato.

Ao afirmar no ato principal que "murcha os 4 pneus" e "chama a polícia”, a solicitante explicita sua indignação de modo direto e intensificado. Algumas formulações indiretas podem soar de forma autoritária para o interlocutor; é o caso das asserções iniciadas com "eu quero", das asserções contendo modalizadores com valor de obrigação (você tem de se calar/ você deve se calar) e das asserções no futuro do presente do indicativo (você fechará a porta/vai fechar a porta ao sair) ou presente do indicativo (você cala a boca), as quais são consideradas como ordens. Trata-se de ordens disfarçadas de asserções, de enunciados indiretos, mas que nem por isso deixam de ser extremamente diretivos (Kerbrat-Orecchioni, 2005).

Por fim, a expressão "Entendeu ou preciso desenhar" (sem ponto de ponto de interrogação, mas com valor interrogativo) evidencia uma atitude provocadora. $\mathrm{O}$ uso do verbo entender no passado, voltado diretamente para o falante, parece querer atestar se a 
enunciadora foi clara no que disse, porém ela não espera respostas, apenas pretende reforçar a sua fala anterior.

Em E6 também temos um enunciado que não faz referência ao ato propriamente dito, porém pode ser interpretado por meio de pistas como um pedido e, sobretudo, como uma ameaça. É certo que os enunciados deste exemplo não se enquadram na condição de proibição nem transmitem a força ilocucionária de um comando, o que pode ser resultado da constituição dos atos de apoio "cão tranquilo" e "cuidado com o dono" em forma nominal. Desse modo, cabe a imagem de uma arma direcionada ao leitor do aviso para tornar o grau de imposição do pedido mais elevado. É nela que se encontra a principal informação do pedido. Assim, o que poderia ser apenas um aviso do tipo "Entrada proibida" adquire contornos impositivos por meio de modificador externo não verbal. Com isso, embora não seja prevista a classificação de ilustrações na teoria de Blum-Kulka e Olshtain (1984) nem neste trabalho, consideramos as imagens que por vezes atuam como protagonistas dos avisos evidenciados neste trabalho, como atos de apoio, devido a fato de modificarem o impacto do pedido, atenuando ou intensificando a força do enunciado, ou ainda servindo para persuadir o ouvinte a fazer algo.

A partir da análise da amostra do corpus explicitada acima, notamos que as escolhas linguísticas, denotadoras de ameaça, não acontecem aleatoriamente, mas tendem a ser motivadas por experiências pessoais e/ou coletivas, predominantemente desfavoráveis e recorrentes em diferentes situações enunciativas.

Nesses casos, fica nítido que não há preocupação por parte do solicitante em preservar a sua face positiva nem a face negativa do interlocutor. A insatisfação contida nos acontecimentos evidenciados abre espaço para um tratamento linguístico baseado no confronto, seja ele na forma direta ou indireta.

As formas de impolidez, desse modo, parecem indicar que é importante e pertinente pensar, no caso brasileiro, não só no comportamento polido, já muito explorado em diversos estudos, mas também no não polido. É preciso assumir a cordialidade em sua face dupla - e não negá-la -, pois essa visão sempre positiva, pacífica e ordeira, dificilmente ajudará a lidarmos com nossa própria realidade tal como ela se apresenta de fato. 


\section{2}

\section{Agressividade}

Enquanto a ameaça caracteriza-se pela intimidação mediante a promessa de causar algum mal a alguém, a agressividade, grosso modo, é uma tendência em agir ou responder de forma violenta, com a intenção de machucar ou provocar dano a outra pessoa. A agressão, segundo Houaiss $(2009$, p. 23), pode se concretizar porser um "ataque à integridade física ou moral de alguém", um "ato de hostilidade, de provocação", ou "ofensa ou insulto com palavras". Esses comportamentos são, geralmente, motivados por competitividade ou raiva, que resultam em prejuízo, distanciamento, dificultando o estabelecimento de uma boa relação entre as partes envolvidas.

Assim como a ofensa, a agressividade também é um ato socialmente reprovado, pois visa provocar o estremecimento das relações entre os interlocutores.

Por meio desta categoria semântica, ao proferir o pedido, o solicitante exterioriza seu desejo em atingir alguém na sua honra, na sua dignidade como podemos ver, a seguir, nos seguintes dados do corpus:

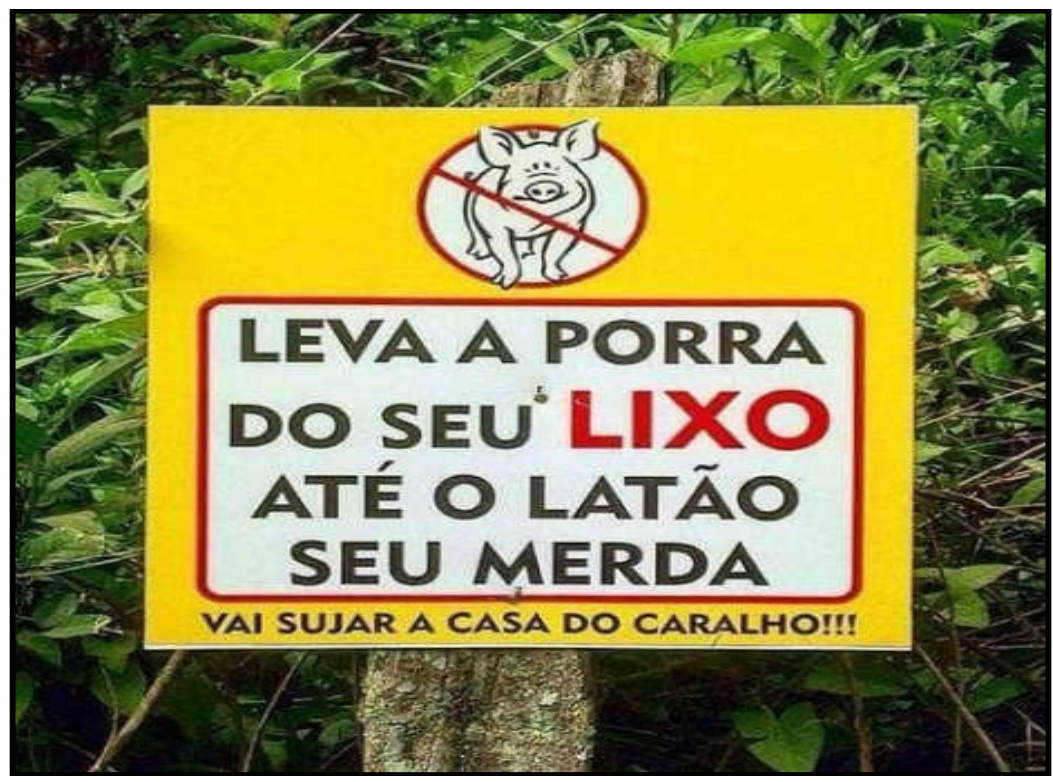

E7 


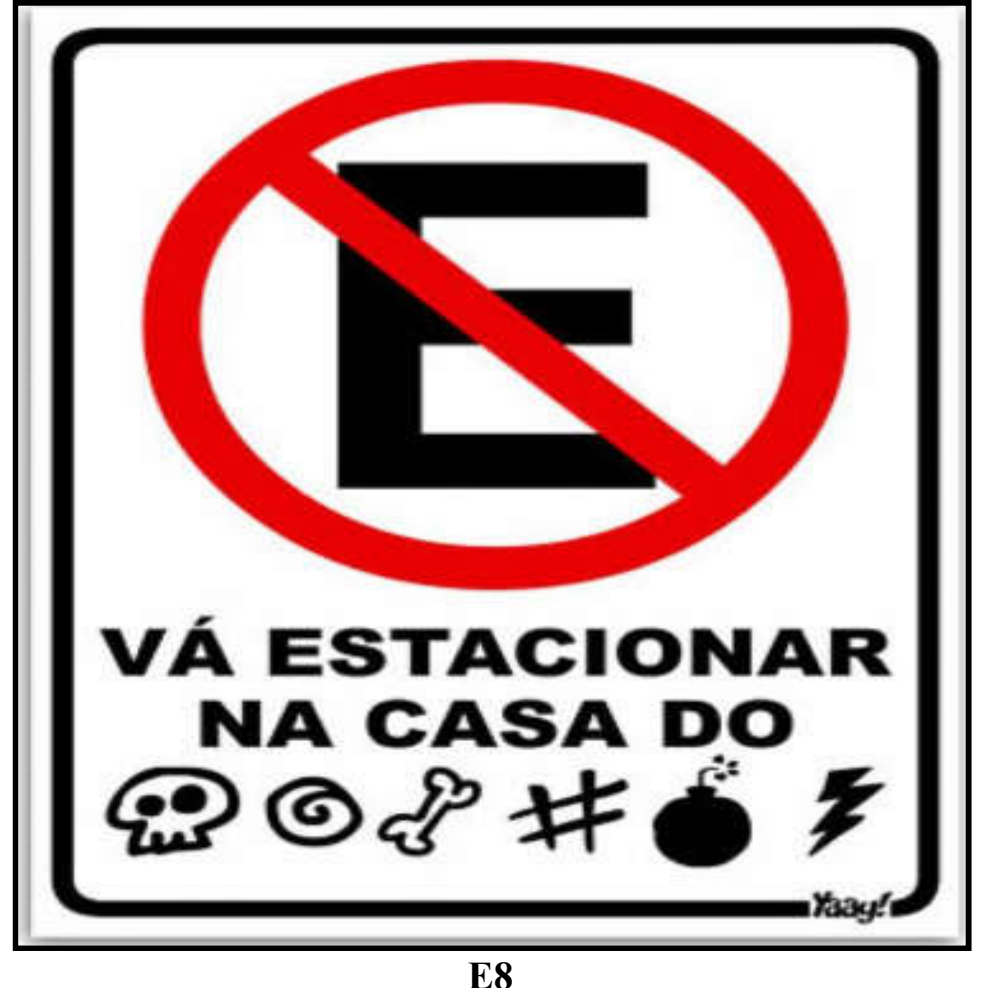

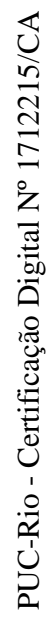

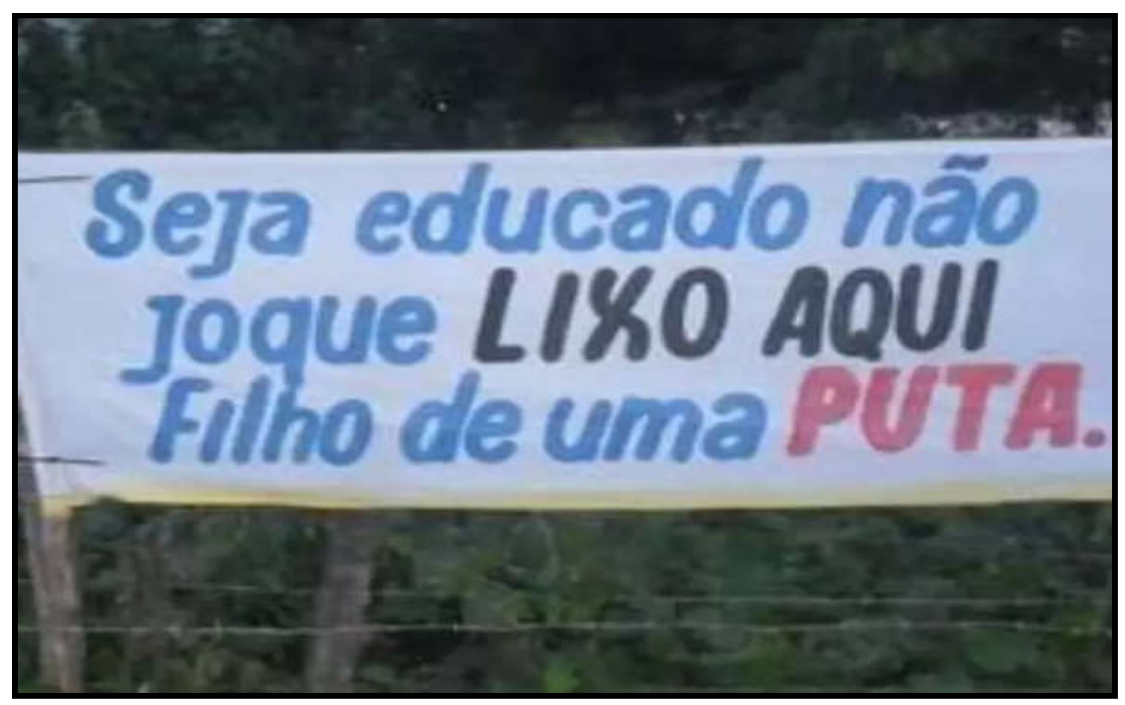

E9 


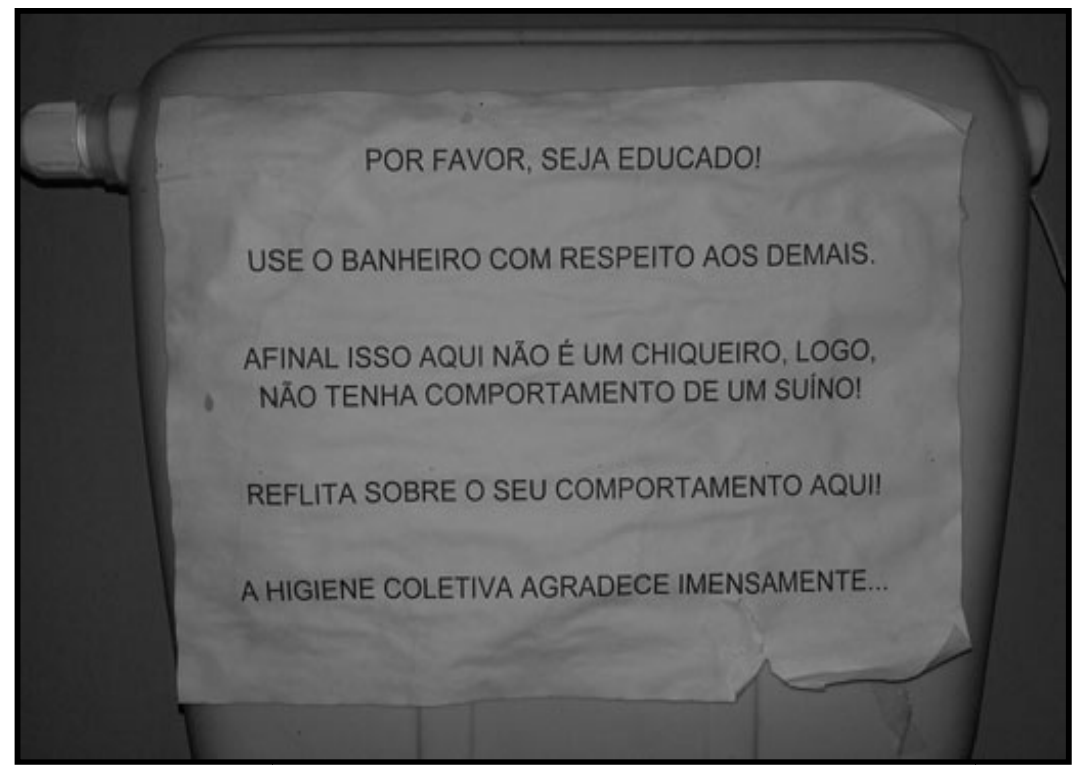

E10

Ao observarmos as amostras do corpus referentes à categoria agressividade, concluímos que, dentre a escala de 9 graus de diretividade de Blum-Kulka \& Olshtain (1984), os pedidos apresentados acima denotam o tipo de estratégia modo derivável, considerado o mais direto.

Nos exemplos vemos que, apesar de os solicitantes terem elaborado o pedido de forma direta, os mesmos não foram atenuados por meio de estratégias linguísticas de polidez. O que se percebe é que mesmo em um contexto marcado por uma recíproca vulnerabilidade, como na realização dos atos de pedir, os solicitantes optaram por agir de forma contrária ao padrão de comportamento esperado nessas situações, ou seja, não tentaram evitar atos de ameaça à face para minimizar qualquer tipo de mal-estar decorrente do ato em si.

Assim, verifica-se, em E7, que o primeiro pedido ("leva a porra do seu lixo até o latão") é constituído pelo verbo levar no tempo verbal imperativo informal. A presença do palavrão porra, combinado com verbo, funciona como um intensificador do pedido e imprime ao ato um tom agressivo. Segundo Preti (1984:39-40), esse tipo de vocabulário constitui um elemento de contestação social que revela insatisfação e inconformismo perante determinada situação, e pode atuar como válvula de escape para o enunciador. O palavrão, nesse caso, ilustra bem a revolta do solicitante e se revela como um ataque aberto à imagem do interlocutor.

Seguindo essa mesma tendência, observamos ainda no enunciado a presença do endereçamento "seu merda" e do ato de apoio “vá sujar a casa do caralho!!!”, que corroboram 
a indignação do solicitante. Quanto a esses tipos de expressões, faz-se importante dizer ainda que, apesar de, no português do Brasil, o uso de termos com conotação negativa e do palavrão serem proferidos na fala cotidiana, de certa forma são reprovados socialmente no dia a dia, mesmo em situações em que o enunciador tenha motivos e esteja com a razão para utilizar tal vocabulário. Tais usos comprovam o quanto é importante discernir os diferentes contextos enunciativos para o sucesso da comunicação.

Já em E8, encontramos um pedido constituído apenas pelo ato principal ("Vá estacionar na casa do*?\#d@!"), realizado de forma direta, com o verbo ir no imperativo formal, sem a utilização de recursos atenuadores. Nota-se aqui mais uma vez o uso do palavrão "a casa do caralho", porém, neste caso, expresso por caracteres, mas possível de ser inferido facilmente por falantes nativos do português do Brasil. Segundo Dias (2010), a formulação de uma solicitação pode ser endurecida por diferentes unidades agravadoras, que incluem insultos, ameaças e moralizações. Essa função é exercida pelos símbolos que nos permitem inferir que o solicitante deseja comunicar sua insatisfação, sugerindo não querer nenhuma proximidade com seu interlocutor. Embora as figuras substituam o palavrão, consideramos que estas não atenuam a agressividade, mas auxiliam no tom imperativo do pedido.

Por sua vez, no enunciado E9, "seja educado não jogue LIXO AQUI filho de uma puta”, percebemos uma prática recorrente nos pedidos agressivos: o uso de letras maiúsculas, como no ato principal "não jogue LIXO AQUI”. Ao usar letras maiores, o solicitante transmite a sensação de que fala alto, grita com o seu interlocutor, a fim de adverti-lo. Para tal, é comum registrar pedidos impositivos totalmente nesse formato (como nos enunciados acima) ou selecionar apenas palavras que atendam melhor o propósito do emissor. Nessa ocorrência, por exemplo, o substantivo "LIXO" aponta qual o principal problema da situação enunciada, enquanto o advérbio locativo "AQUI" reforça o lugar onde este não deve ser despejado. Ainda há o termo de endereçamento "filho de uma PUTA" que, embora se constitua como um todo depreciativo, tem como elemento destacado somente a palavra que possui maior força ofensiva. Obersva-se também que na expressão "filho da puta" é utilizado o item lexical "uma", que funciona como um elemento importante para enfatizar a agressividade ao seu interlocutor.

Em E10, apesar de ser um pedido menos sucinto em relação aos outros, considera-se este não menos direto e claro quanto a sua intenção. O pedido apresenta uma sequência de solicitações com verbos no tempo verbal imperativo: "seja educado, use o banheiro com respeito aos demais e reflita sobre seu comportamento aqui", convocando o interlocutor a agir 
adequadamente. No entanto, na sequência do enunciado, há indícios de um discurso mais agressivo que pode ser visualizado nos termos "chiqueiro" e "suíno", nos quais o enunciador associa o comportamento dos usuários aos porcos.

É importante observar que todas as elocuções são feitas no tempo verbal imperativo, sem acompanhamento de atenuadores, o que marca uma postura autoritária do enunciador. Fica claro para o leitor que o solicitante já não suporta mais sofrer as consequências do desrespeito causado pela falta de educação naquele espaço.

Sendo assim, a rua, como um "local de individualização, de luta e de malandragem, zona onde cada um deve zelar por si, enquanto Deus olha por todos", segundo DaMatta (1997, p. 55), é um espaço onde se podem admitir contradições, agressividade, perigo, insegurança, pois é um lugar propício a desgraças e roubos, lugar de arruaças, de desordem, espaços ocupados por indivíduos anônimos e desgarrados. A rua, portanto, é o espaço onde há apenas o indivíduo, que não é tomado como pertencndo a uma família, mas que luta e zela por si individualmente, tendo encontrado na sua própria língua uma das formas para se defender.

\section{Indiretos}

A seguir, apresentam-se exemplos de indiretividade não convencional da categoria agressividade, os quais se incluem na estratégia de pistas fortes (Blum-Kulka \& Olshtain, 1984).

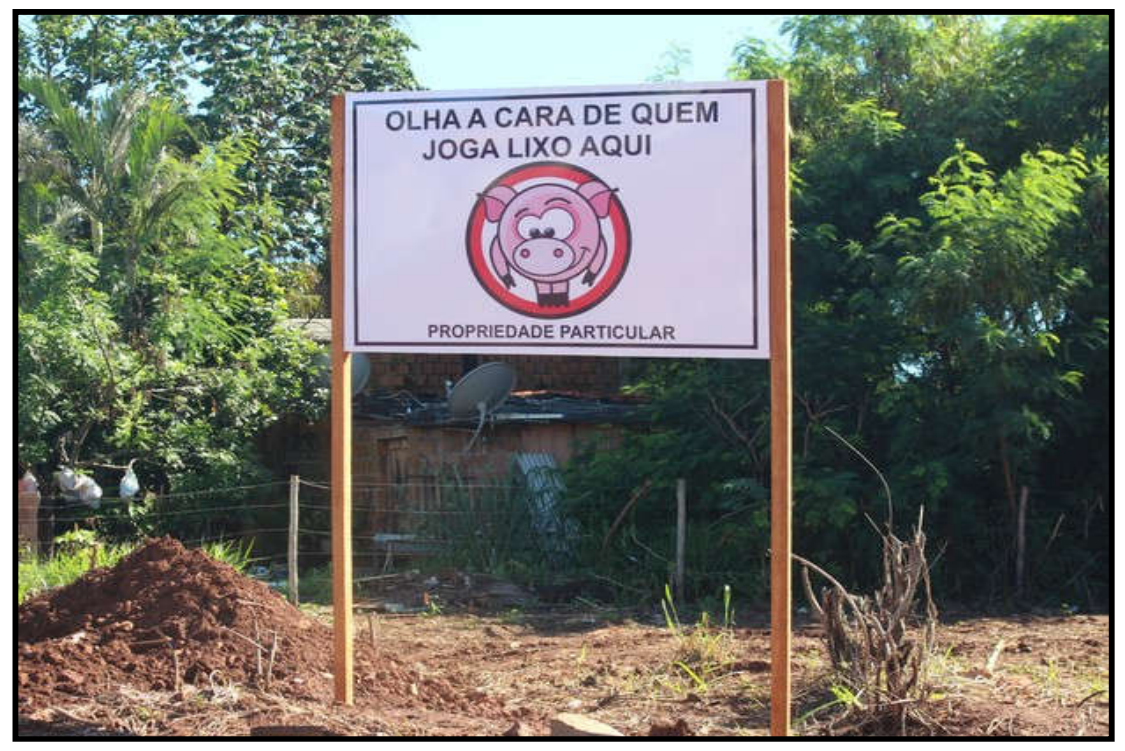

E11 


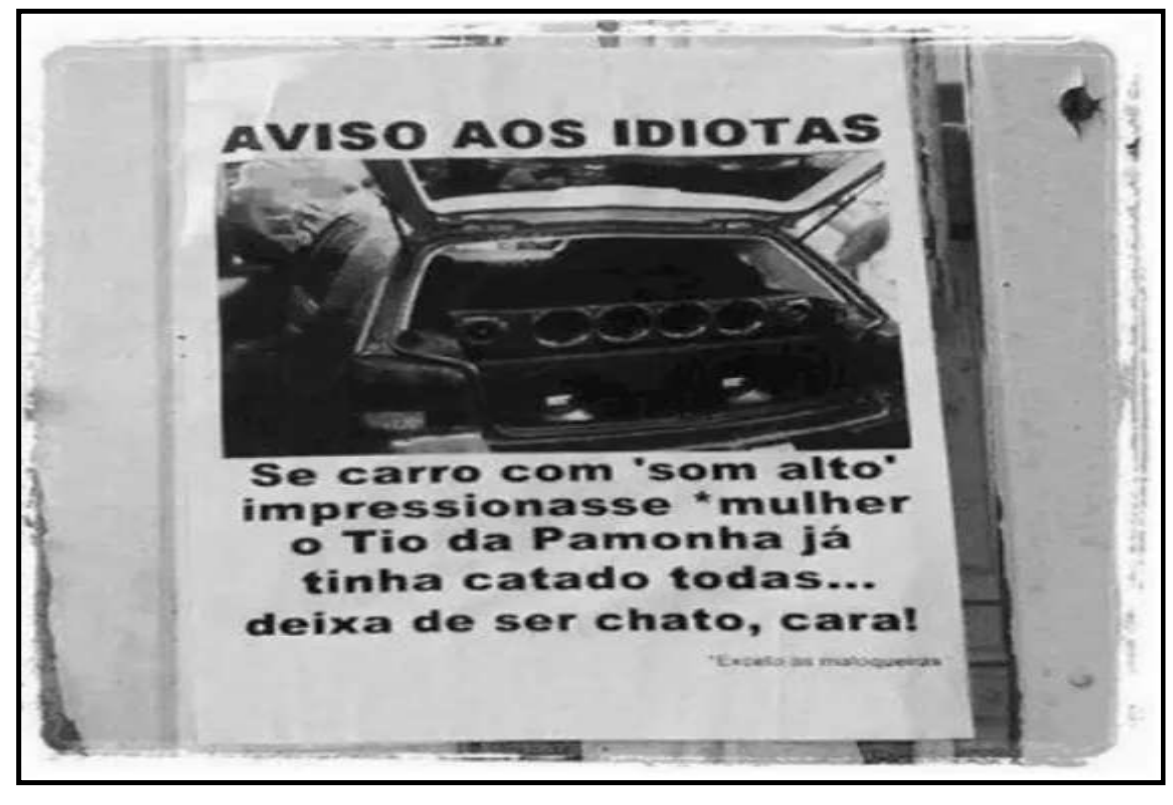

E12

Uma das vantagens de se optar por uma estratégia off Record, segundo Brown e Levinson (1987:69-73), é ser visto como alguém que possui gentileza no trato e age de forma não coercitiva, pois o significado pode ser negociável. De acordo com os autores, estratégias off record satisfazem não só a face negativa do interlocutor num grau maior do que estratégias de polidez negativa como também possibilitam que o locutor não se comprometa.

No entanto, os exemplos acima mostram não haver necessariamente uma correspondência direta entre o uso de estratégias indiretas e o desejo de não se impor sobre o interlocutor.

Segundo os referidos autores, ao mostrar que o interlocutor está errado, enganado ou é imprudente a respeito de alguma questão, o locutor ameaça a sua face positiva. O que vemos em (E11) é um pedido de mudança de comportamento por meio de pistas que implicam, de certa forma, reprovação da atitude do interlocutor em relação ao fato de jogar lixo em uma propriedade particular. O uso do verbo olhar no ato principal "Olha a cara de quem joga lixo aqui" chama a atenção do leitor para a imagem mostrada na placa e intenciona constranger aqueles que pretendem agir inadequadamente.

A ideia generalizada de que o porco é um animal sujo, impuro e repleto de significações pejorativas é nesse caso transferida ao "ser humano". O uso da imagem do porco, nesse caso funciona como ato de apoio (Blum-Kulka e Olshtain, 1984), pois agrava a força impositiva do enunciado diretivo, sendo um ataque aberto à imagem da pessoa envolvida na situação. 
Em E12, encontramos outro pedido que convoca a uma mudança de comportamento. Nele, o solicitante primeiramente utiliza um endereçamento ofensivo (Aviso aos idiotas") para introduzir seu pedido. Por meio dele, o locutor agrava a força impositiva das sequências seguintes realizando antes um ataque à imagem do interlocutor. A palavra "idiotas" faz um insulto coletivo a um grupo específico, ou seja, àqueles que deixam veículo com porta-malas aberto e som alto, audível pelo lado externo, em local residencial, perturbando moradores da vizinhança, pedestres e demais condutores, conforme ilustra a imagem. Dias (2010) classifica esse tipo de estratégia como a de agravadores, em que o locutor os utiliza quase que exclusivamente nas situações em que os pedidos implicam alguma reprovação sobre determinado comportamento do destinatário.

Seguindo essa tendência, o ato de apoio "Se carro com som alto impressionasse *mulher o tio da Pamonha já tinha catado todas..." expressa, através de uma estrutura condicional, um fato que não ocorre, isto é, o interlocutor não impressiona nenhuma mulher pelo fato de deixar o som alto ligado. Nesse caso, o locutor transmite a ideia de que o interlocutor, na verdade, incomoda.

Ao fazer menção ao "Tio da Pamonha", o solicitante emprega um tratamento tipicamente pertencente ao ambiente da casa para se referir a um homem pertencente ao espaço da rua, externo às relações consanguíneas. O emprego de "tio", nesse caso, faz referência aos vendedores informais que costumam anunciar em altos falantes pelas ruas das cidades brasileiras a venda da pamonha ${ }^{10}$. No Brasil é muito recorrente o uso de tal termo para se referir a pessoas de mais idade com quem temos um relacionamento sem parentesco, como para se dirigir a estranhos com a finalidade de criar um efeito de proximidade.

Esse movimento é um caso bem representativo do que DaMatta (1997) observa na sociedade brasileira conforme seus conceitos de casa e rua: brasileiros costumam estender as confortáveis relações pessoais da casa para incluir pessoas que normalmente se encaixariam no ambiente da rua. Desse modo, é comum tratar com afetividade e intimidade quem, embora próximo, não é verdadeiramente família e assim transformando, por exemplo, os vizinhos, os amigos dos pais ou os parentes de amigos em seus próprios familiares.

Apesar dessa característica, o uso do termo no cartaz parece não ter a intenção de buscar proximidade, mas querer enfatizar ao interlocutor que a prática imprópria cometida por ele não funciona, visto que nem o vendedor de pamonha obtém sucesso com o som alto.

\footnotetext{
${ }^{10}$ Bolo de milho verde, leite de coco e outros ingredientes, cozido em folhas do próprio milho, ou da bananeira. Disponível em: <https://www.dicio.com.br/pamonha/https://www.dicio.com.br/pamonha/>. Acesso em: 02/08/19.
} 
Com vista a repreendê-lo, a estrutura do ato principal traz a perífrase "deixa de", convocando o interlocutor a não continuar a fazer o que tem feito. O uso da palavra "chato", utilizada para se referir a pessoas inconvenientes, reforça o seu aborrecimento em relação ao fato, que é reforçado também pelo ponto de exclamação ao final do enunciado.

A partir das considerações feitas nesta seção, acreditamos ter identificado, em nossos dados, pedidos que contradizem a teoria de Brown e Levinson (1987), que sugere haver uma correlação entre preservação da face, polidez e indiretividade. Vemos que, além da ameaça à face positiva do interlocutor, as pistas acima são, simultaneamente, uma ameaça, um ato de desagravo a sua face negativa: a estratégia utilizada impõe ao interlocutor uma mudança de planos e de comportamento, ou seja, tenta impedir que ele mantenha sua decisão e crie novos hábitos.

\section{3}

\section{Apelo}

Segundo o dicionário da língua portuguesa "apelo" "11 significa o "ato ou efeito de apelar, de pedir auxílio"; pode ser também uma "solicitação feita em nome de algo ou alguém", ou ainda uma "chamada ou convocação". Sendo assim, o apelo é uma mensagem construída com a intenção primeira de persuadir. É, pois, o meio pelo qual exercemos influência sobre nossos interlocutores ou leitores, de modo a modificar uma ideia do indivíduo ou ainda incitá-lo a uma nova ação.

Ao analisarmos as amostras do corpus referentes a essa categoria, concluímos que os pedidos apresentados abaixo incluem-se, segundo Blum-Kulka e Olshtain (1984), nas estratégias diretivas diretas performativo atenuado (E12) e modo derivável (E13 e E14). A perspectiva dos pedidos está orientada para os solicitantes.

Vejamos a seguir os exemplos:

\footnotetext{
${ }^{11}$ Disponível em: < https://www.dicio.com.br/apelo/>. Acesso em: 16/07/19.
} 


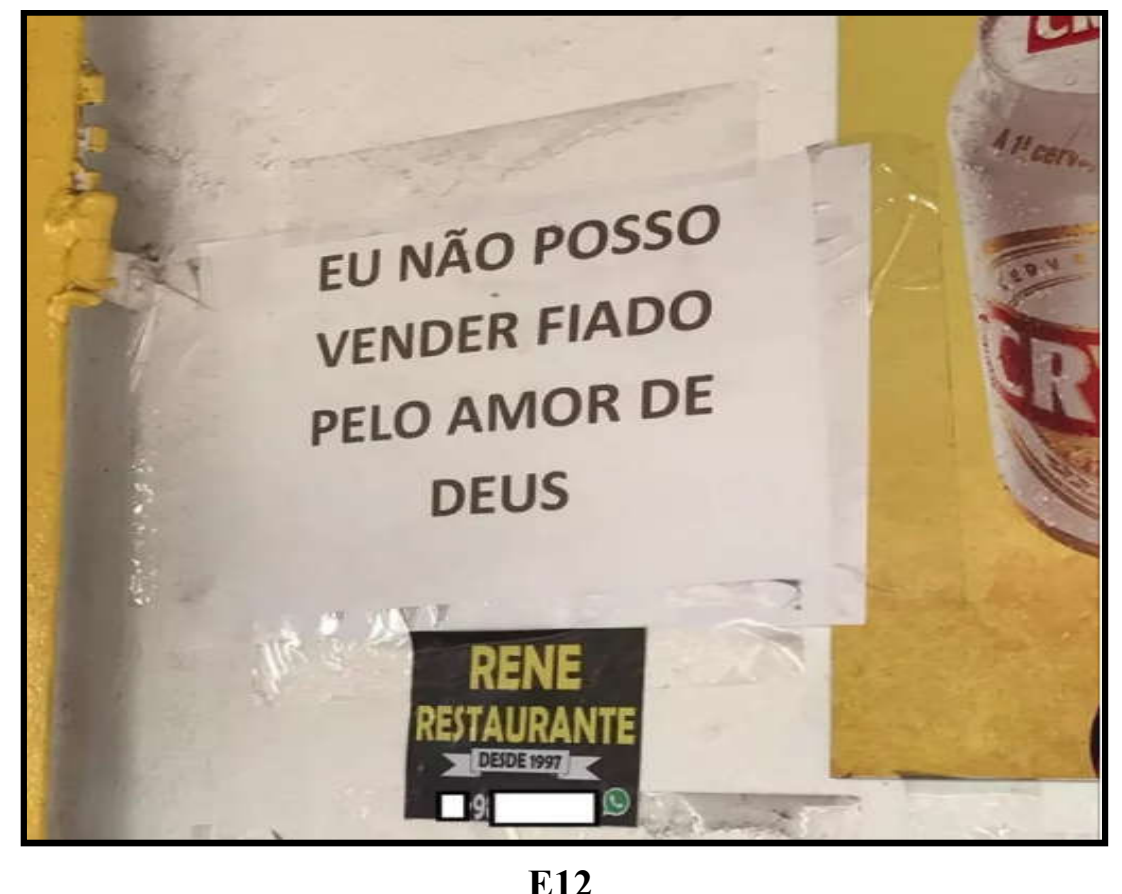

Ũ

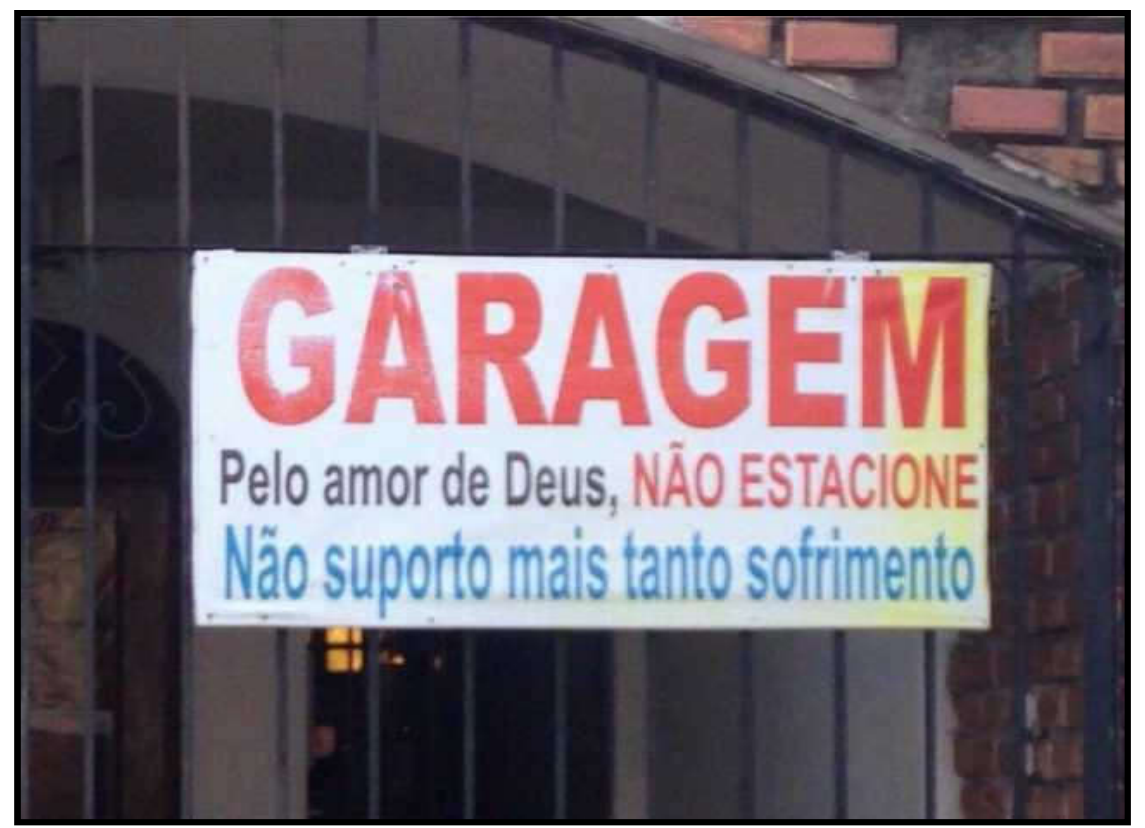

E13 


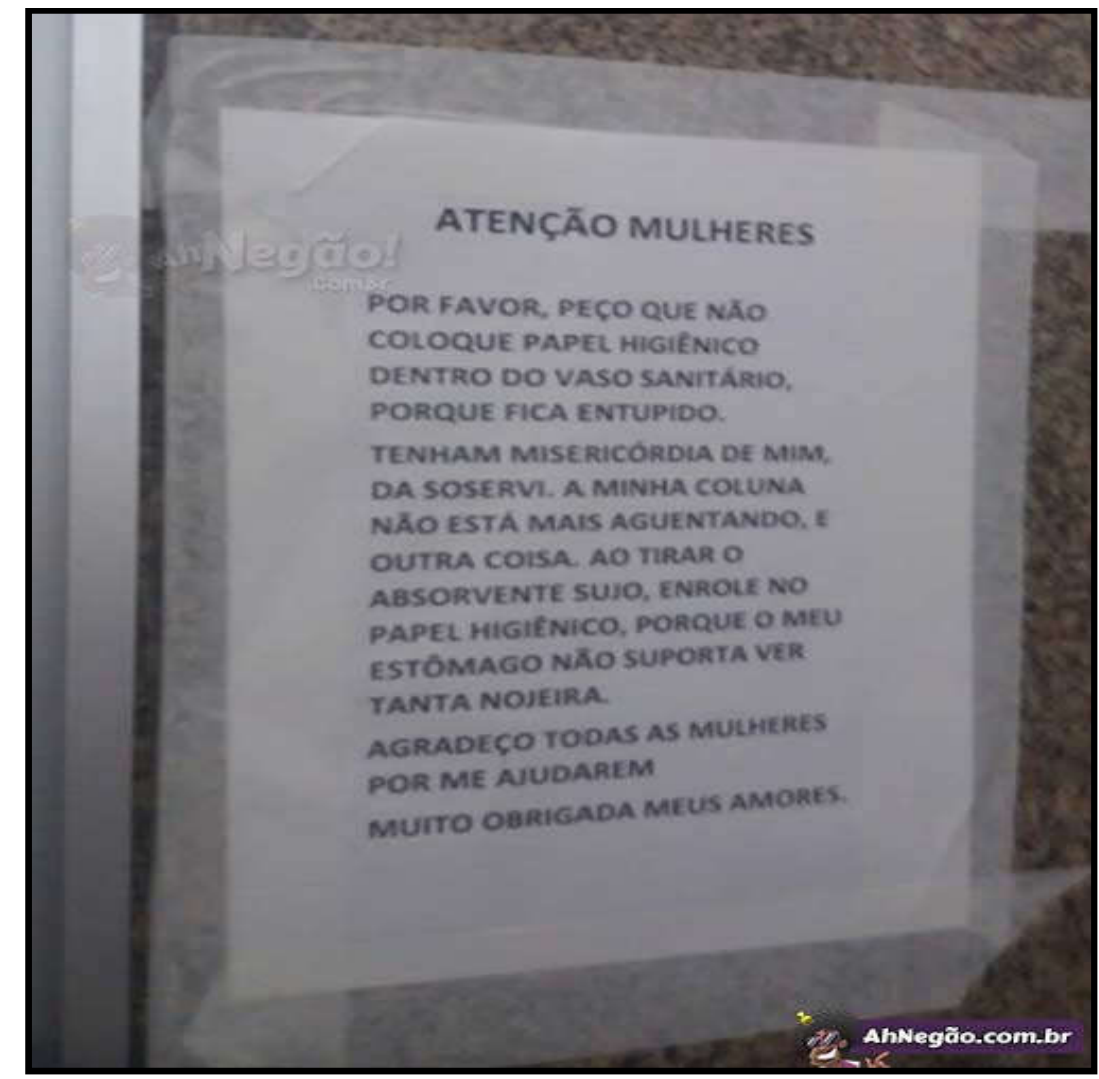

E14

Como bem observa Freitas (1997), o brasileiro tende a manifestar um desejo contínuo de estabelecer intimidade, buscando, geralmente, um elo pessoal nas relações impessoais. A busca de proximidade, o compartilhar de experiências pessoais, o jeito de se expressar e a demonstração de que uma determinada situação é necessária parecem ser indispensáveis à obtenção de auxílio, mesmo que os interesses em jogo estejam no espaço da rua (DaMatta, 1987).

Com isso, observamos nos exemplos acima que, apesar de os solicitantes serem as vítimas da situação enunciada, estes tenderam a compensar o caráter impositivo do apelo, acompanhando o ato principal com uma série de procedimentos adicionais, que mitigam (“muito obrigada meus amores; pelo amor de Deus") e reparam ("por favor") a solicitação feita de forma direta.

Além da combinação das estruturas mitigadoras de contato, como os agradecimentos antecipados, justificativas ("porque meu estômago não suporta ver tanta nojeira"), e das expressões cristalizadas de polidez, podemos destacar em E12 a opção do solicitante em usar a construção "Eu não posso vender fiado", com o verbo no presente do indicativo, ao invés da 
construção imperativa "eu não vendo fiado", na tentativa de diminuir a rudeza do ato de fala (Cunha e Cintra, 2014, p. 493).

Segundo Blum-Kulka e Olshtain (1984), nos performativos atenuados, como em E12, a força ilocucionária é menos impositiva. Entretanto, os pedidos sem qualquer atenuação dos performativos manifestam a intenção do solicitante de forma bastante direta, podendo soar impolidos caso não haja modificação suficiente de atenuadores. Assim, o uso do imperativo na sua forma não modificada comunica as intenções do locutor muito claramente, transmitindo a força ilocucionária de uma ordem, como no caso do imperativo negativo "Não estacione" (E2).

Nessa perspectiva, o brasileiro, sempre caracterizado por tentar se aproximar e tornarse íntimo nas relações interpessoais (Holanda, 1995), procura, então, criar uma relação mais íntima com seu interlocutor através de escolhas lexicais e sintáticas que produzam efeitos de sentido de não imposição. Desse modo, percebemos em E13 e E14 o uso de referências diretas ao próprio requisitante por meio dos verbos - "não suporto" (E2), "peço", "agradeço" (E3) - e do pronome - "mim" - em primeira pessoa, a fim de criar aproximação, empatia e, dessa forma, conseguir solidariedade do interlocutor para a realização da ação desejada.

Percebemos ainda que, nos exemplos E13 e E14, o uso de um apelo divino, por meio da expressão de esfera religiosa "Pelo amor de Deus", evidencia um aspecto expressivo da cultura brasileira. Segundo Albuquerque (2003, p. 137), expressões de cunho religioso, tais como Nossa Senhora!, Deus me livre!, Meu Deus do céu! e Pelo amor de Deus!, em geral, revelam valores negativos e são constantemente utilizadas nas conversas espontâneas entre os brasileiros. Considerando seu uso nas placas e cartazes, é possível também verificar essa conotação negativa, aliada ao aborrecimento do locutor com as práticas sofridas. Porém, poderíamos dizer ainda que esse tipo de expressão parece ter a intenção de dar ênfase ao pedido, bem como de comover o interlocutor, envolvendo-o de forma a provocar sua compaixão.

\section{Indireto}

Ao contrário dos pedidos diretos, voltados para perspectiva do falante, as estruturas em E15 e E16, independentemente dos fatores contextuais, atuam na perspectiva geral e na direção da conciliação do todo, logo são impessoais. Abaixo, vemos dois casos de pedidos indiretos não convencionais, tendo o primeiro exemplo na categoria de pistas fortes e o segundo na de pistas moderadas. 


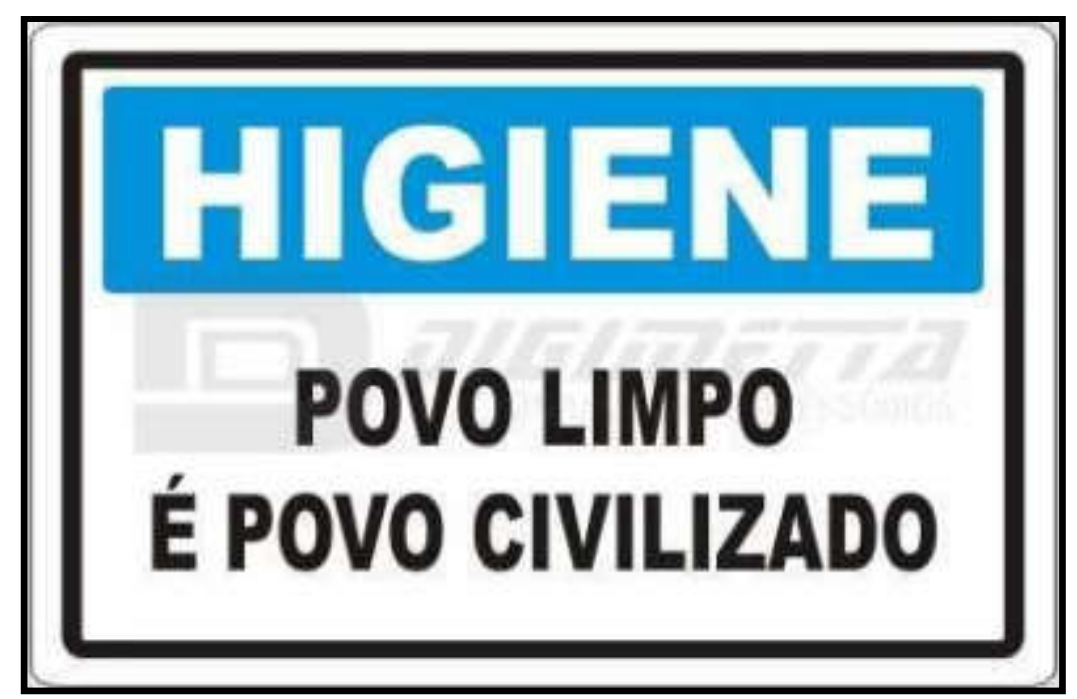

E15

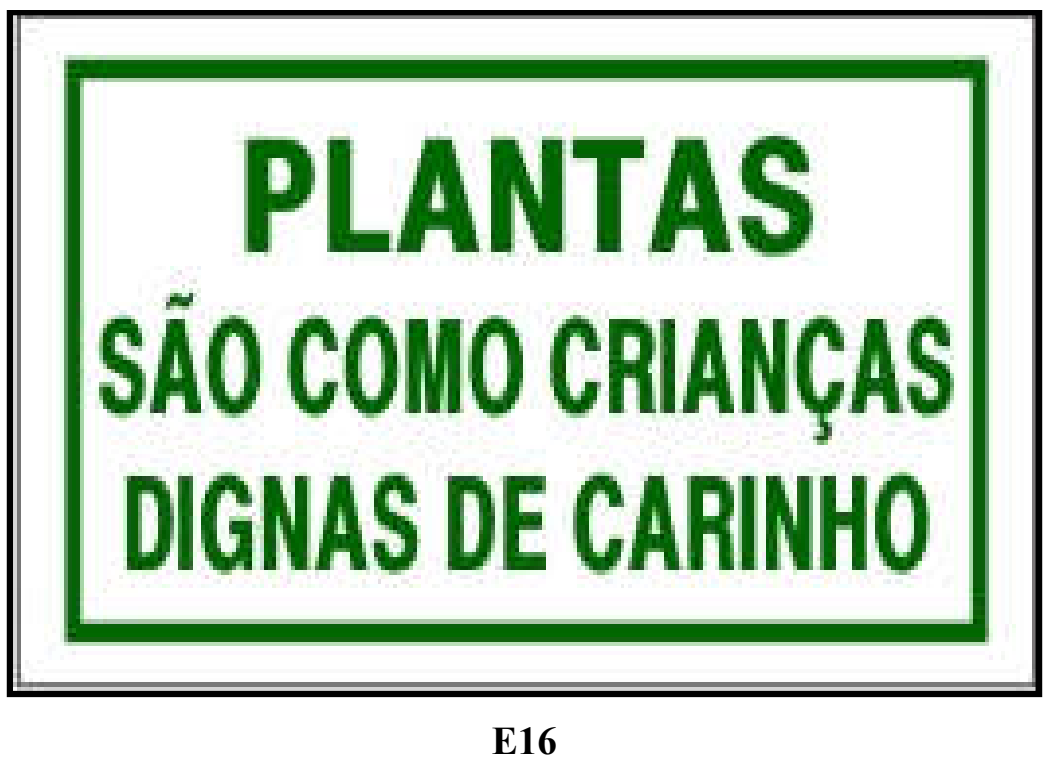

Como vimos anteriormente, as estruturas diretas dos pedidos apelativos são formas que recorrem a acréscimos opcionais, como as de cunho religioso para atenuar a força impositiva do pedido, fazendo-o parecer mais uma súplica do que propriamente um pedido. Por outro lado, na amostra de pedidos diretivos indiretos, referentes a essa categoria, encontramos enunciados menos efusivos, porém não menos apelativos.

A vagueza dos enunciados resultante da falta de referência explícita a algum dos elementos essenciais do ato pretendido (o que se deseja que seja feito e/ou quem deverá fazêlo, como mostram os exemplos), resulta em uma estratégia do solicitante para salvar a própria 
imagem e, também, a imagem de interlocutor (Brown e Levinson, 1987). No entanto, consideramos que, por si só, a indiretividade não-convencional desses pedidos não os livraria de um certo grau de imposição sobre o interlocutor, já que estes implicitam uma reprovação.

Desse modo, consideramos, que o enunciado "Povo limpo é povo civilizado" (E15) poderia significar simplesmente uma asserção. Entretanto, se inserido em um contexto comunicativo específico, o significado deste enunciado poderia ser, entre outros: "Mantenha o ambiente limpo", "Preserve este espaço", "Lave as mãos após uso do banheiro", sentidos diversos que nesse caso seriam alcançados através de inferências, sendo compreendidos, portanto, como uma advertência. Da mesma forma, o enunciado "Plantas são como crianças dignas de carinho" (E16) poderia também apresentar diferentes significações, tais como "Não pise na grama", "Não arranque as plantas", entre outros.

Quanto ao aspecto de súplica, observa-se que em E15, o uso dos adjetivos "limpo" e "civilizado", associados à palavra "povo", busca criar uma identificação dos interlocutores com a declaração enunciada, convocando-os a fazer parte de uma coletividade que tem "Higiene", assim como pressupõe o ato de apoio. Já em E16, vemos o estabelecimento de uma comparação, denotada pelo conectivo "como", para convencer e sensibilizar o interlocutor a cumprir o pedido. Ao associar as palavras "planta" e "criança", o locutor apela para a fragilidade desses seres, elevando-as a um estado sublime, que demanda maior cuidado e atenção.

Observamos, portanto, que a categoria das estratégias indiretas inclui pedidos em que a ação esperada do interlocutor não é claramente especificada. Os enunciados utilizados pelo locutor guiam os pensamentos do leitor e dão a entender que há uma solicitação sendo feita. Esse trabalho de inferência pode demandar menor ou maior esforço, ou seja, quando o desejo ou as necessidades do locutor são mencionados parcialmente, como em (E15), dizemos que a pista é forte, mas quando uma afirmação ou pergunta direcionada ao interlocutor os omite completamente, como em (E16), dizemos que a pista é moderada, segundo Blum-Kulka e Olshtain (1984).

Assim, além de serem constituídas por pistas linguísticas, as placas e cartazes também se constituem por si sós como pistas: elas são rastros do modo de vida dos brasileiros espalhados pelo país. Mais do que orientar condutas, terminam por retratar os comportamentos produzidos socialmente, sua manifestação e necessidade de negociação constante.

A conduta incoerente do brasileiro seria uma dessas revelações. $O$ fato de que em casa todos costumam se sentir eseciais, como supercidadãos - lugar onde se podem fazer coisas até 
mesmo condenadas no espaço público -, ao mesm o tempo que na rua agem como subcidadãos, por serem indivíduos anônimos e desgarrados, termina por demonstrar nesses suportes um comportamento extremamente inadequado da sociedade em relação às coisas públicas e também privadas (Oliveira, 2017).

Inevitavelmente, um observador atento dará conta, assim como DaMatta (1997), que há uma cidadania em casa e outra na rua, sendo esta última a mais negativa. Logo, mais do que lembretes, as placas e cartazes, podem revelar a maneira como uma sociedade comportase, comunica-se, relaciona-se e, sobretudo, lida com o ambiente em que vive.

\section{4}

\section{Cordialidade}

Quando se faz referência à palavra cordialidade, automaticamente se associa a ideia de educação, gentileza, amabilidade, ou seja, algo unicamente agradável ou bom. Não poderia ser diferente, uma vez que, ao buscar o significado da palavra no dicionário, a definição encontrada traz exatamente essas características. Segundo o dicionário Aulete (2011, p. 401), cordialidade é a qualidade do que é cordial, e cordial, por sua vez, está relacionado ao que vem do coração, deriva do latim cordialis, que tem por definição aquele que expressa sentimentos genuínos; é afável, cortez, gentil (Geiger, 2011).

De acordo com essa linha de pensamento, ser cordial, portanto, é se deixar levar por suas paixões; é ser receptivo, afetuoso, caloroso, capaz de expressar sentimentos amigáveis inclusive com estranhos.

No entanto, para Sérgio Buarque de Holanda (1995), essa interpretação está apenas parcialmente correta, pois para ele a cordialidade pode expressar tanto amizade quanto inimizade, “[...] visto que uma e outra nascem do coração [...]" (Idem, p. 205). Por ser assim tão ambivalente, o homem pode ser cordial quando é afetuoso, porém não deixa de sê-lo quando também age de forma violenta. Essa dualidade, supostamente polarizada e contraditória, pode, portanto, manifestar-se, explícita ou implicitamente, apresentando traços afetivamente ora positivos, ora negativos, ou, ainda, na integração de ambos.

Vejamos a seguir como a ideia de cordialidade se manifesta em nossos dados: 


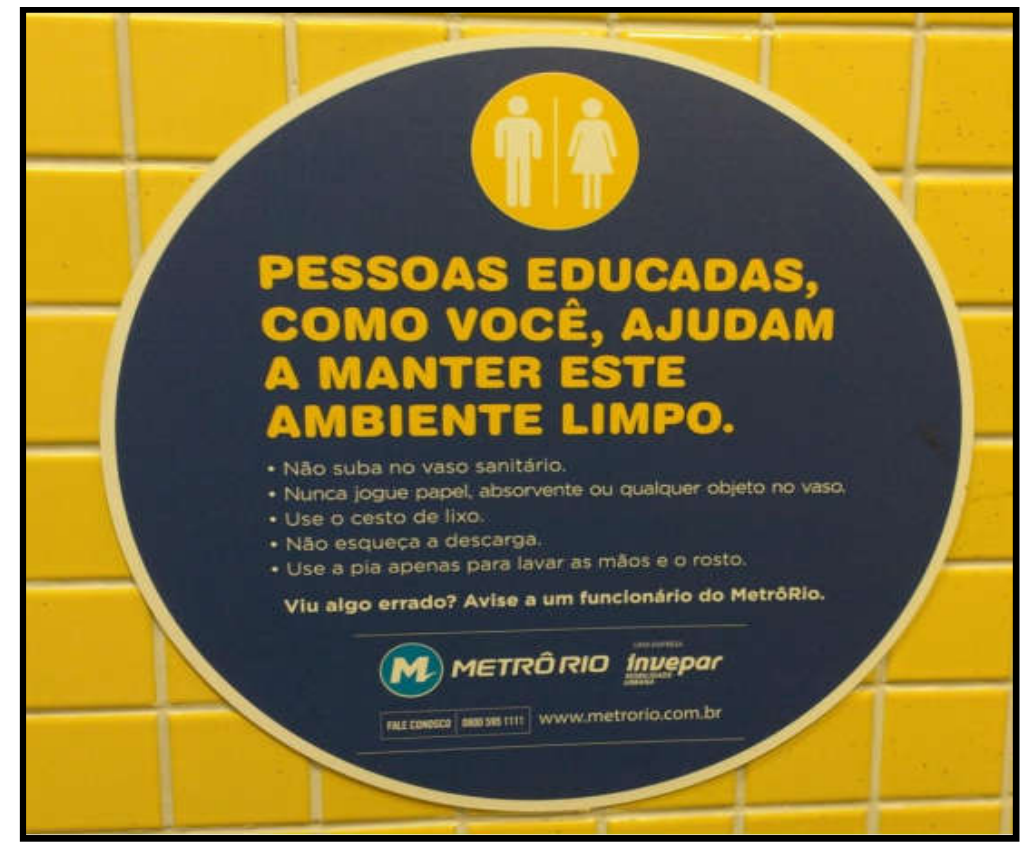

E17

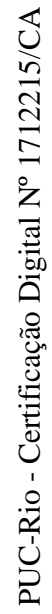

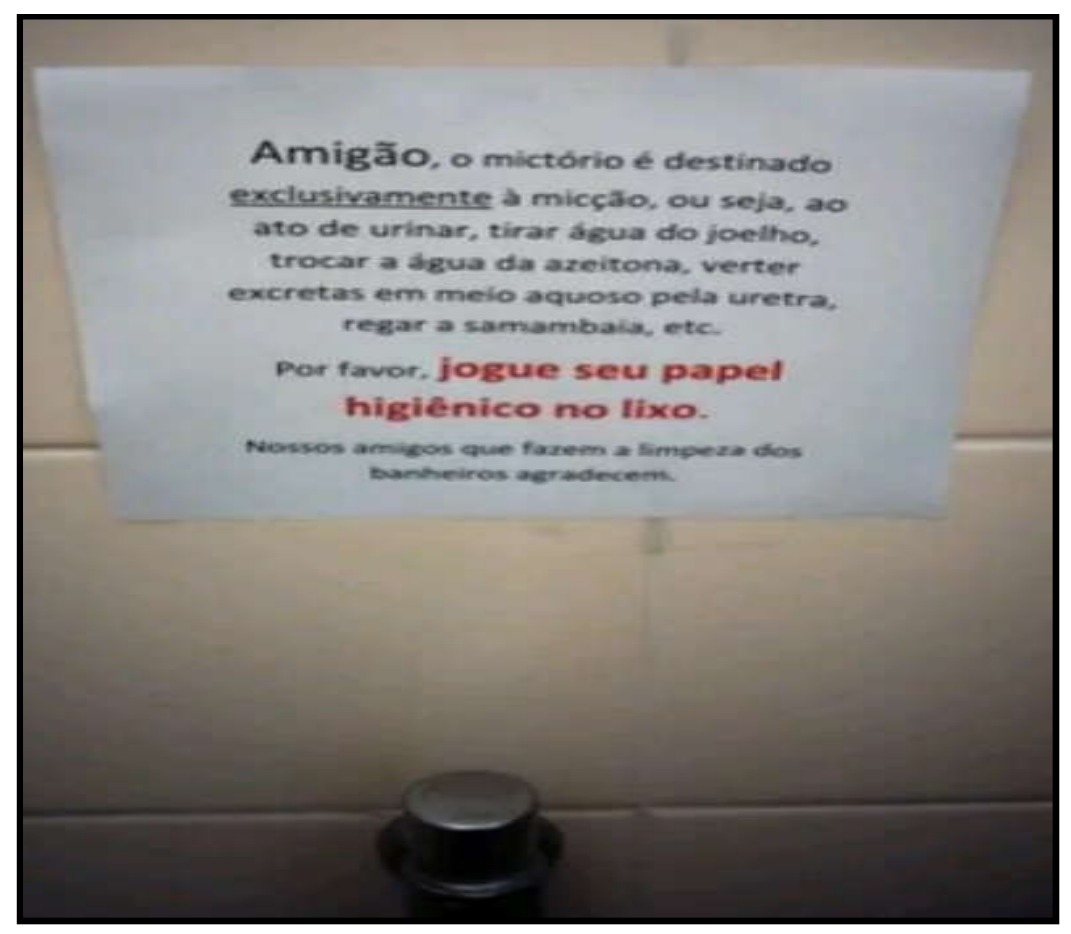

E18 


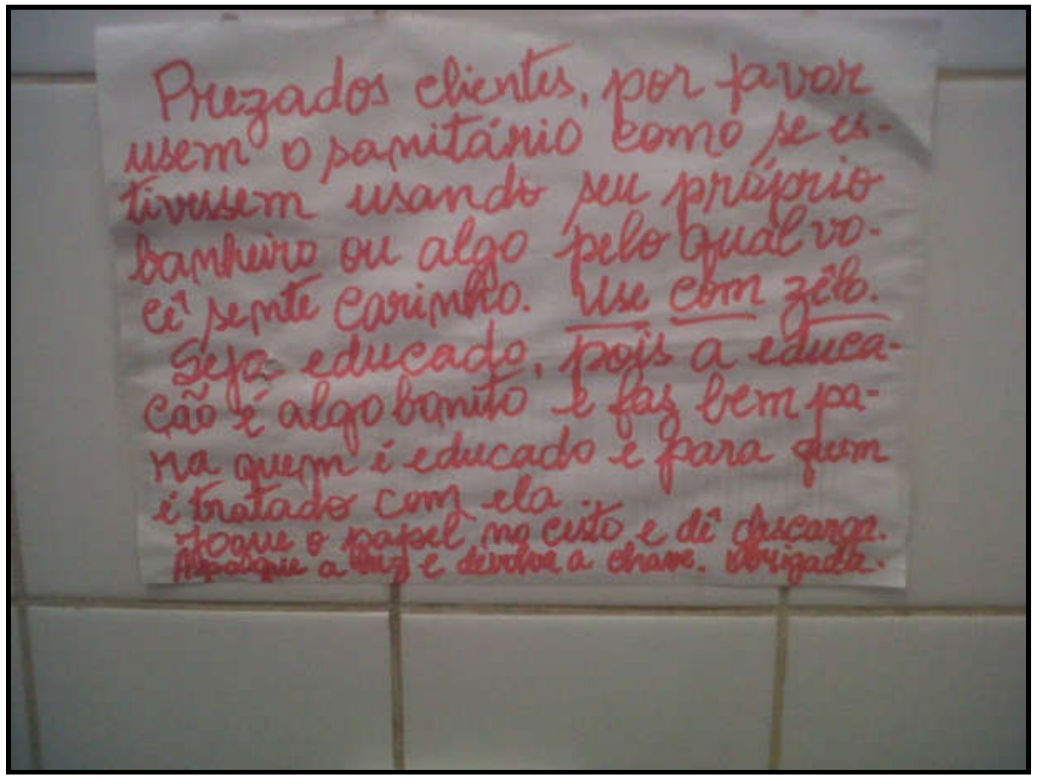

E19

Como podemos ver acima, os pedidos diretivos diretos selecionados na categoria cordialidade referem-se coincidentemente a avisos de banheiros públicos, palco bastante profícuo para manifestações linguísticas do português brasileiro. Ao observarmos as amostras, constatamos que os pedidos apresentados acima denotam o tipo de estratégia: Modo derivável (estratégia 1). Consideramos nesses casos que a perspectiva do pedido está orientada para o interlocutor, ou seja, coloca-o na posição de decidir se os pedidos a ele direcionados serão ou não atendidos.

Analisando os exemplos, observamos, neste primeiro momento, que os pedidos destes espaços foram introduzidos por alertas (reparação antecipada) (Blum-Kulka et al., 1989b). O emprego da expressão de elogio "Pessoas educadas, como você" (E17) -, do vocativo de intimidade "amigão" (E18) - como forma de chamamento no ato de pedir -, ou a forma de tratamento "Prezados clientes" (E19) - como cumprimento de abertura -, já atenua a intenção do pedido e cria uma proximidade entre os interlocutores. Deste modo, percebemos que, em contextos onde não há contato face a face, os brasileiros também lançam mão de estratégias de polidez negativa, valendo-se de valores como a camaradagem e a amizade para preservarem suas próprias ações e, consequentemente, a ameaça às faces dos interlocutores.

Por outro lado, é importante ressaltar que o uso do elogio, no exemplo E17, ou de vocativos com intuito de forçar uma proximidade inexistente entre os interlocutores, como em E18, pode tornar-se também impositivo na medida em que, de certa forma, obriga o interlocutor a reagir de algum modo. 
Em relação ao ato de elogiar, Brown \& Levinson (1987, p. 134), apesar de recomendarem o uso dessa estratégia para satisfazer a face positiva do interlocutor, já alertavam para o fato de que ao fazermos elogios a alguém, devemos saber selecioná-los adequadamente, prevendo a reação dos interlocutores, pois, conforme a intensidade, estes teriam potencial para constituir invasão, afronta, abuso, logo, gerariam custos ao outro e ao próprio solicitante do pedido. Pensar, portanto, o que seria excessivo na estratégia de elogiar e também de fazer referências de familiaridade ao interlocutor faz muito sentido no contexto do ensino de línguas, uma vez que os efeitos associados a eles estão sujeitos à interpretação cultural.

Ainda considerando os aspectos estruturais destes pedidos, encontramos, combinados a essas formas de polidez referenciadas, atos principais elaborados de forma direta e sem ambiguidade, com o intuito de expressar explicitamente o comportamento proibido nestes espaços: "Não suba no vaso sanitário", "Não esqueça a descarga", "Use a pia apenas para lavar as mãos e o rosto" (E17), "Jogue papel no cesto e dê descarga" (E19) são alguns dos enunciados destes avisos que utilizam o modo verbal imperativo formal como estratégia para reforçar o sentido de imposição. Ou seja, intentam educar através de intimações, dizendo para alguém que deve fazer algo, ou comportar-se de determinada maneira.

Especificamente sobre o português do Brasil, nota-se que, apesar de o modo verbal imperativo ser considerado uma forma rude na nossa cultura para se dirigir ao outro (Gripp, 2015:71), este mostra-se adequadamente útil em placas e cartazes, por funcionar como uma espécie de convite à ação, devido principalmente a sua força ilocucionária, direcionada para que o interlocutor cumpra a condição de satisfação do enunciado.

Em vista disso, poderíamos dizer então que nos casos apresentados o enunciador brasileiro "une o útil ao agradável", isto é, seleciona uma forma mais impositiva para manifestar o desejo de que uma ou mais pessoas cumpram a ação indicada pelo verbo; porém, sabendo que "o emprego da forma imperativa para ordens, pedidos e sugestões representa uma atitude demasiadamente autoritária, desprovida de polidez" (Meyer, 1999, p. 150) no português brasileiro, opta por combinar a essas construções, atenuantes lexicais e sintáticos com vistas a minimizar o ato impositivo.

Além dessas estratégias, destacamos também o fato de os solicitantes serem menos objetivos. Em E18 e E19, por exemplo, observa-se que os atos de apoio elaborados para realizar os pedidos são mais longos quando comparados aos atos principais. No primeiro exemplo, destaca-se, após a expressão "exclusivamente à micção", a referência a diferentes expressões relacionadas ao ato de urinar (“tirar água do joelho, trocar a água da azeitona, 
regar a samambaia", etc.) com a intenção de enfatizar a função exclusiva do mictório. Em E19, por sua vez, encontramos um conjunto de construções precedentes ao ato principal destinadas a criar um efeito de posse ("seu próprio banheiro"), informalidade ("algo pelo qual você sente carinho") e afinidade ("a educação é algo bonito"), que parecem trabalhar juntas na tentativa de tentar envolver / persuadir o interlocutor a realizar o ato que está em jogo.

Notamos, ainda, nos exemplos dessa categoria, o uso da expressão cristalizada de polidez "por favor", da expressão de agradecimento "obrigada", além da construção "Nossos amigos que fazem a limpeza do banheiro agradecem" como elementos mitigadores de contato. Nesse último, vemos que o uso do pronome "nosso", acompanhado do substantivo "amigos" para se referir ao grupo que cuida da limpeza do banheiro, cria efeitos de sentido que procuram romper com possíveis distanciamentos que possa haver entre os envolvidos na situação enunciativa e visam causar um efeito de proximidade entre os interlocutores, em prol da cooperação.

A partir das considerações acima, vemos que os avisos em banheiros públicos no Brasil, além de serem uma forma de lidar com o comportamento humano nesses contextos, revelam um jeito próprio de lidar também com situações que deveriam supostamente ser cobertas de rigores e formalismos. Consideramos que o fato de sermos uma sociedade baseada em relações fez o brasileiro desenvolver a necessidade de tornar os relacionamentos mais próximos e familiares, sejam eles pessoais ou mediados. Assim, mesmo em situações pertencentes à rua, lugar do indivíduo, onde todos deveriam ser iguais (DaMatta, 1997), evitam-se ao extremo as soluções violentas, prefere-se a conciliação, a amizade, a criação de um elo pessoal. Essa postura, de acordo com Holanda "parece constituir, ao menos até agora, o traço mais específico do espírito brasileiro" (1995, p. 149).

\section{Indiretos}

Tratando-se dos exemplos indiretos da categoria cordialidade, notamos que o desejo de manter a conciliação na interação discursiva se faz presente. Abaixo, vemos três casos, segundo Blum-Kulka e Olshtain (1984), de pedidos indiretos não convencionais, que podem orientar-se para o ouvinte e para o falante. Vejamos a seguir as amostras selecionadas: 


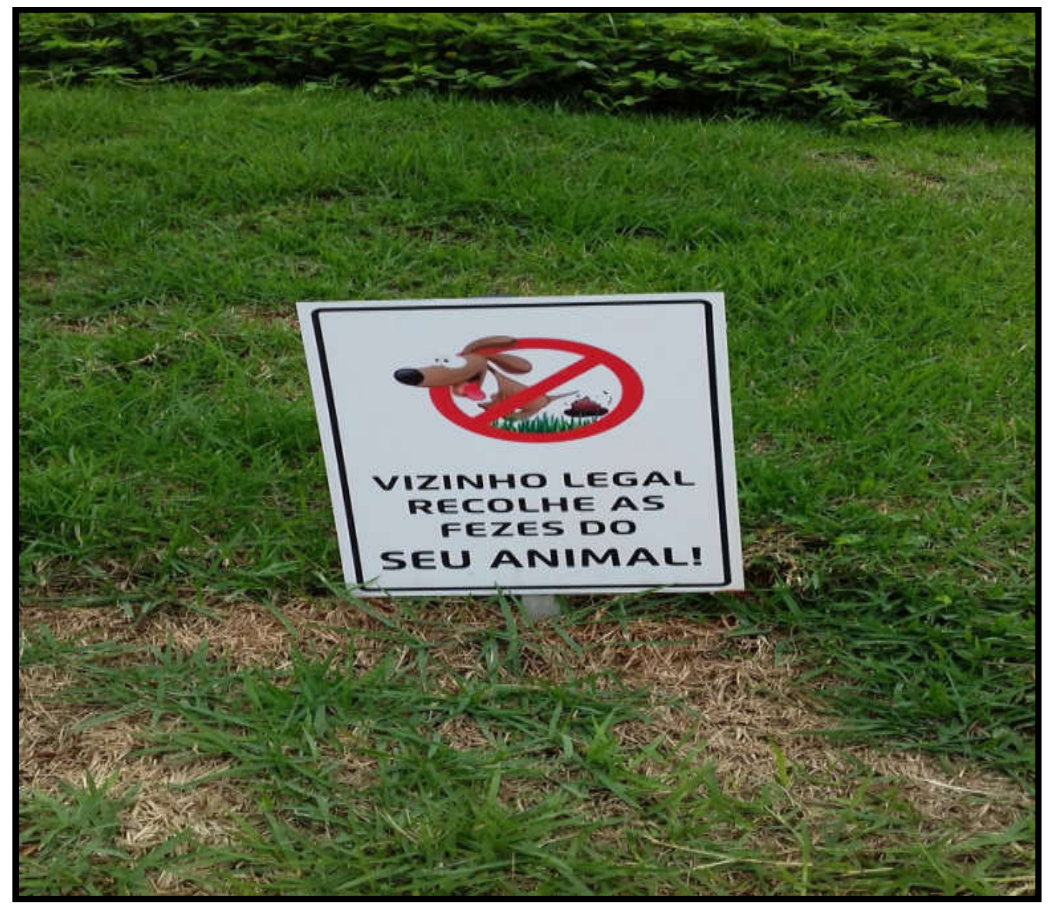

E20

U

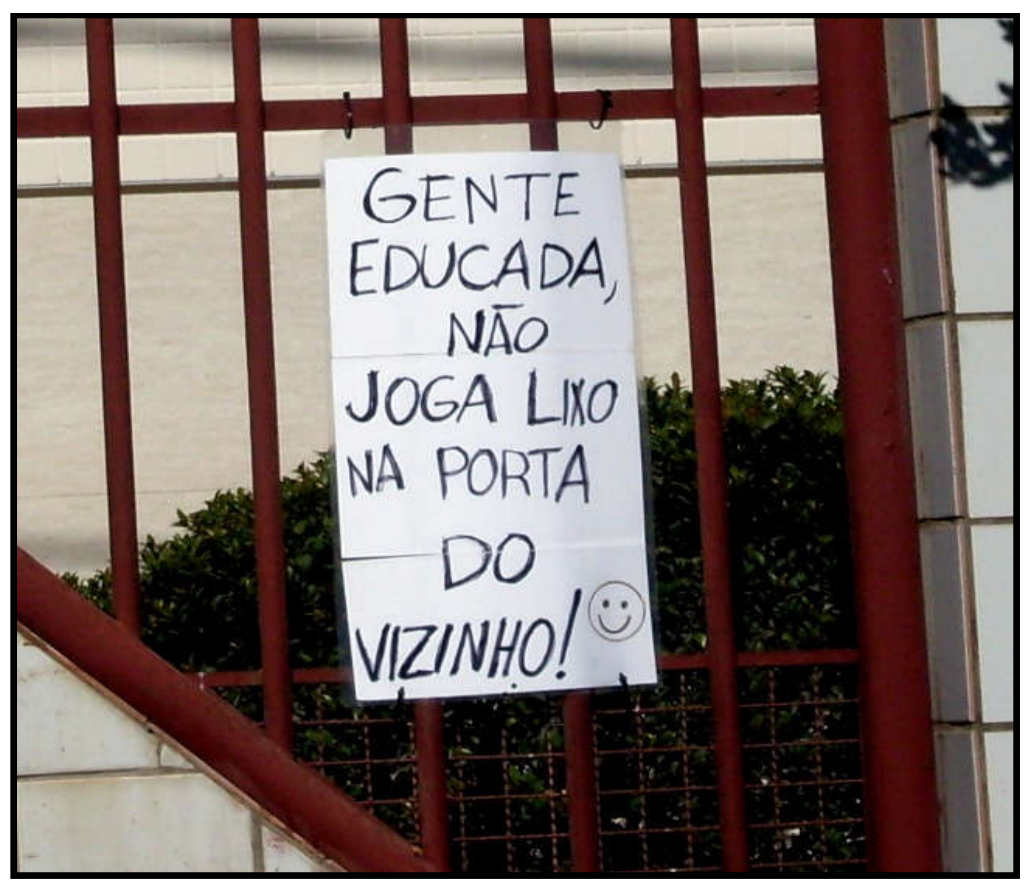

E21 


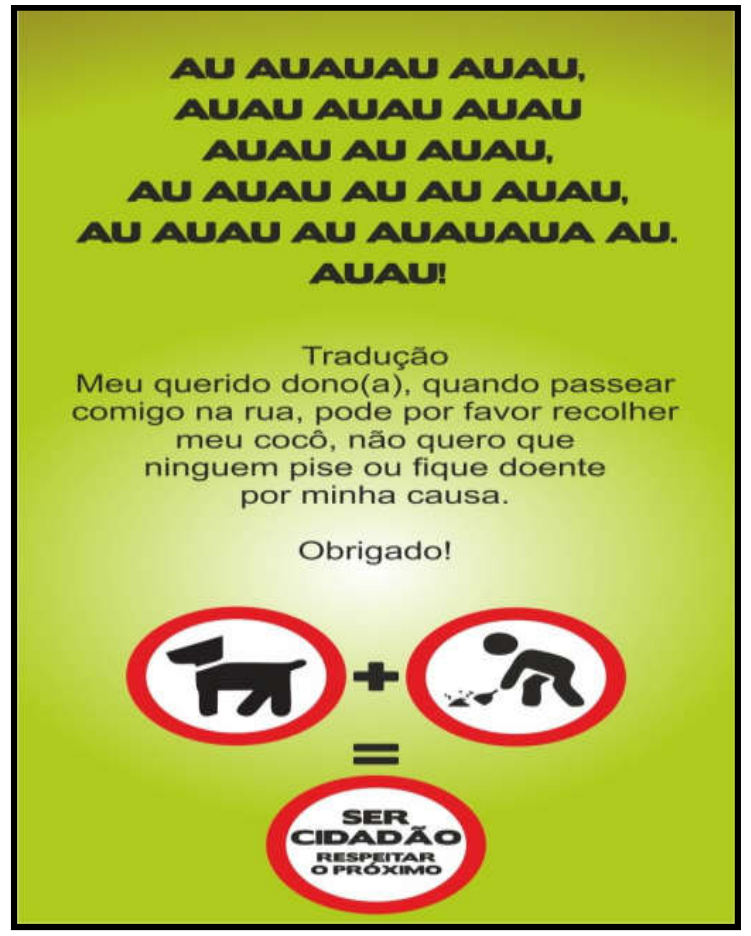

E22

Nestas ocorrências, os solicitantes não fazem o pedido diretamente ao seu leitor. A elaboração das construções com sujeitos genéricos permite que o solicitante se refira a um número não definido de possíveis referentes (que podem ser eventualmente todos) em um certo contexto.

Assim, vemos nos exemplos que, ao utilizar expressões constituídas de adjetivos positivos - "vizinho legal"; "gente educada"; "meu querido dono"-, o solicitante lança mão de estratégias de polidez que refletem respeito e simpatia a quem se direciona; dentre os interlocutores previstos se incluem tanto os que já agem com boas condutas nesses espaços, quanto os que agem de maneira inadequada também. Sabe-se, implicitamente, que esses avisos não se direcionam a esse segundo grupo de pessoas, porém o solicitante, ao fazer uso da estratégia elogio, pretende motivar a mudança de comportamento daqueles indivíduos, para que eles não sejam mais a exceção e sim a regra.

Desse modo, apesar de considerarmos tais pedidos como cordiais devido às formas de direcionamento, é preciso sinalizar que o que está por trás dessas referências é a outra face da cordialidade, ou seja, a desarmonia. Isto é, os pedidos são voltados justamente àqueles que não são tão "legais, educados e queridos" perante o grupo em que estão inseridos.

A indiretividade, portanto, vem ao encontro da necessidade de o brasileiro manter as aparências, ainda que as circunstâncias mostrem o contrário. O nosso caráter, de modo geral 
voltado para o desejo de aceitação e segurança, nos faz recorrer a uma espécie de "pseudo polidez" (Batista, 2004) ao invés da crítica, do ataque à imagem ao outro, que poderia levar ao conflito e, inclusive, a reações violentas.

Com isso, supomos que há uma maior necessidade de o locutor cercar-se de estratégias persuasivas dessa natureza. Em E22, por exemplo, o solicitante apela para o som reproduzido pelo cachorro ("auauau auau") para convencer o seu interlocutor a realizar a situação evidenciada nas imagens. Ao simular a comunicação do animal com seu dono, demonstra que a boa conduta é um desejo partilhado por todos, inclusive pelo próprio animal. Neste exemplo, destaca-se, ainda, o fato de o solicitante recorrer a uma construção possessiva com o pronome "meu" acompanhado do vocativo "querido dono" para se direcionar ao interlocutor do pedido. $\mathrm{O}$ emprego desse recurso linguístico criaria uma proximidade entre o falante e o interlocutor, aumentando o grau de carga emocional e dando uma sensação de maior afetividade e intimidade entre os envolvidos da situação enunciada (Neves, 2000, pp. 471490).

A partir da análise dos exemplos desta categoria, vemos que tais usos revelam a forte tendência do brasileiro a converter suas relações humanas ao nível pessoal e afetivo. Contudo, entendemos que essa tendência pode ser tanto para o bem quanto para o mal. A cordialidade não é apenas um estado de benevolência, mas também de malevolência (Holanda, 1995, p. 146): esta pode manifestar-se, explícita ou implicitamente.

Sendo assim, o brasileiro dotado de um caráter conciliatório e de intuição linguística cria e transfere para o mundo da rua, o mundo da casa; ele consegue ser pessoa onde normalmente se é indivíduo, para alcançar aquilo que almeja. Assim, é por meio dessa escolha que ele consegue evitar a incerteza. A igualdade da rua é uma aventura e um espaço de possibilidades improváveis, por isso, segundo DaMatta (1997), pode ser mais seguro permanecer no mundo da casa, um espaço coletivo, entendido como de solidariedade e de gente de bem.

\section{5}

\section{Disciplina}

Segundo o repositório de significados online ${ }^{12}$, Disciplina é a obediência ao conjunto de regras e normas que são estabelecidos por determinado grupo. Também pode se referir ao cumprimento de responsabilidades específicas de cada pessoa.

\footnotetext{
${ }^{12}$ Disponível em: <https://www.significados.com.br/disciplina/ >. Acesso em: 15/07/19.
} 
Do ponto de vista social, a disciplina ainda representa a boa conduta do indivíduo, ou seja, a característica da pessoa que cumpre as ordens existentes na sociedade. Neste aspecto, o oposto de disciplina, a indisciplina, ocorre quando há a falta de ordem, regra, comportamento ou de respeito pelos regulamentos.

Como já dito, cada grupo social possui o seu próprio conjunto de normas e regras de conduta, que variam de acordo com os seus preceitos. O significado de manter a disciplina no trabalho ou na vida social, por exemplo, são diferentes, visto que para cada parte as regras e os comportamentos costumam variar, de acordo com aquilo que consideram de maior importância. Ademais, como diz Chauí (1999), cada cultura valida determinados juízos e valores, e invalida outros de acordo com seus princípios, definindo para seus membros o que devem respeitar ou detestar.

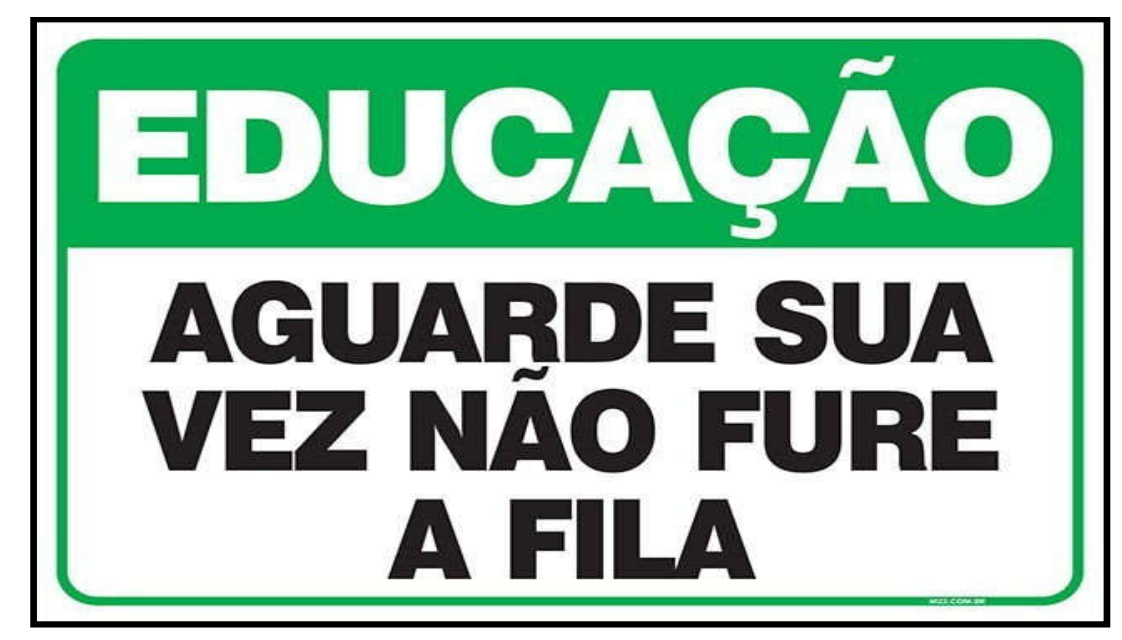

E23

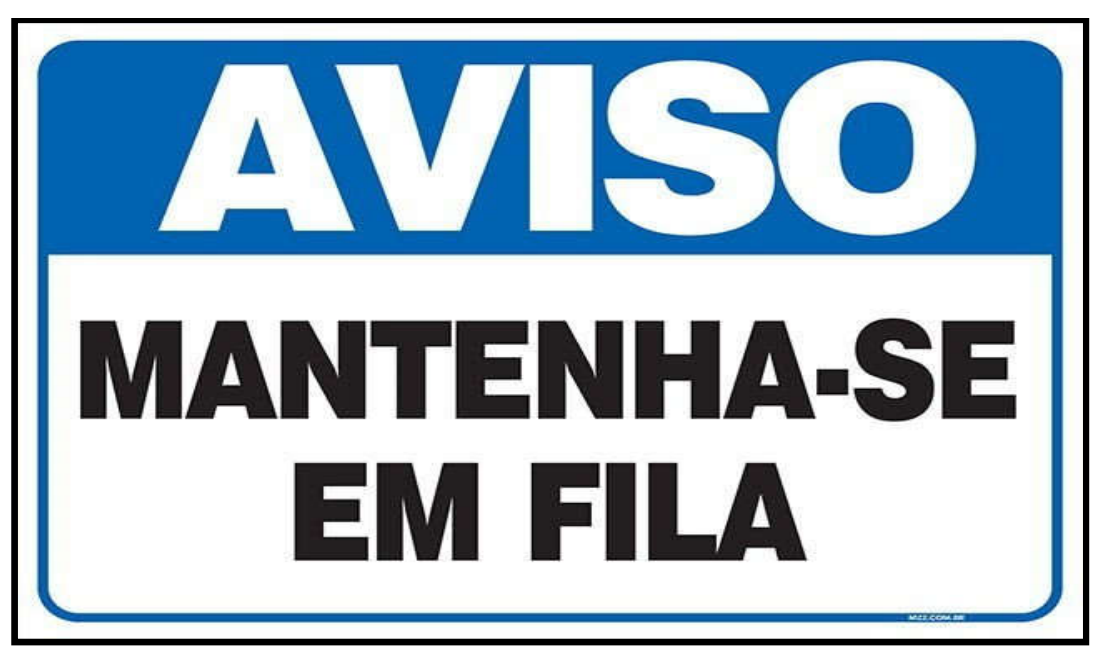




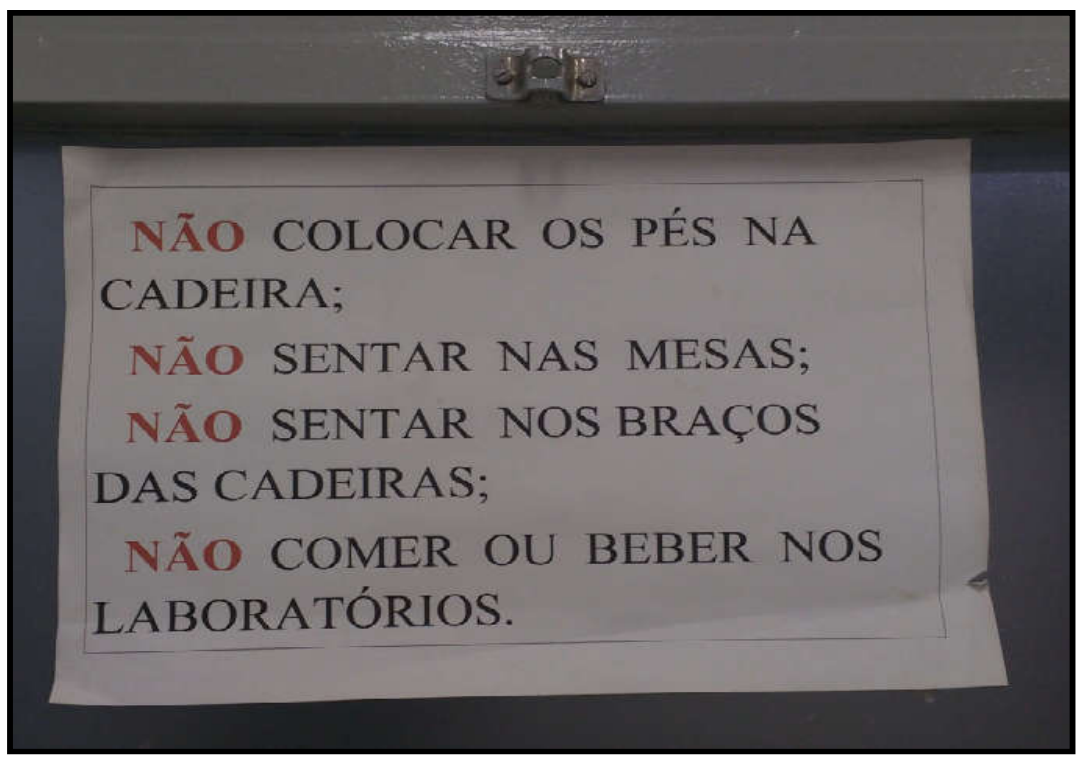

E25

Ao observarmos as amostras do corpus referentes à categoria disciplina, concluímos que os pedidos apresentados acima denotam o tipo de estratégia modo derivável. Nestes casos, o ato de fala é direto, sendo realizado por formas linguísticas especializadas para tal fim. A perspectiva dos pedidos está orientada para os solicitantes.

Encontramos, em E23, um aviso constituído por dois atos principais: "Aguarde a sua vez" e "Não fure a fila". Ambos apresentam o verbo no modo verbal imperativo formal. O título - "EDUCAÇÃO" (destacado com fundo verde e em letras maiores) -, precedente aos atos principais, funciona como elemento de abertura do pedido. Essa indicação funciona como uma abertura de texto e, por meio desta indicação, o locutor pré-anuncia a informação a ser compartilhada com o seu interlocutor.

É interessante registrar que, em geral, avisos feitos em gráficas fazem uso de títulos tais como "Atenção", "Higiene", "Lembre-se" e "Educação", não com o intuito de atenuar ou agravar a força ilocucionária do ato principal, mas servindo simplesmente para orientar o discurso em direção ao conteúdo do que vai ser solicitado, sendo uma espécie de unidade orientadora do discurso. Aqui consideraremos esses recursos como atos de apoio.

Percebemos ainda, neste exemplo, que, embora as construções com o imperativo sejam sempre orientadas para o ouvinte (Dias, 2010, p. 127), o solicitante utiliza, no primeiro ato principal, o pronome possessivo sua para enfatizar a referência direta ao interlocutor. 
O exemplo E24 também se insere na análise que acabamos de fazer, porém nesse aviso encontramos uma estrutura mais sucinta, somente com um ato principal ("Mantenha-se em fila"), constituído do imperativo reflexivo.

Como podemos perceber, a formulação de ambos os pedidos são mais pontuais, padronizados e parecem obedecer a uma dada composição (presença de título, letras maiúsculas e uso de cores com a finalidade de destacar). Estes tipos de avisos são muito comuns em estabelecimentos corporativos, repartições públicas, universidades, etc.; e costumam ser feitos por empresas especializadas na elaboração de placas voltadas para fins de procedimento e boas condutas. Seus enunciados, portanto, são claros e diretos de modo a conduzir o leitor a uma ação favorável ao espaço.

Por outro lado, em E25 encontramos um aviso mais simples na sua composição, porém não menos objetivo na sua mensagem. Este lembrete traz uma sequência de atos principais, constituído por diferentes solicitações formadas pelo imperativo impessoal - “ Não colocar os pés na cadeira; Não sentar nas mesas; Não sentar nos braços da cadeira; Não comer ou beber nos laboratórios" -. Segundo Cunha \& Cintra, o infinitivo com valor de imperativo impessoal é um dos meios que a língua oferece para expressar ordens e proibições (Cunha e Cintra, 2008). Por apresentar o processo em potência, isto é, por expressar a ideia de ação, o infinitivo minimiza a noção de comando e, por conseguinte, reduz a agentividade - evidente nos casos de imperativo e imperativo + se.

A partir dos exemplos, podemos afirmar que os pedidos da categoria disciplina podem ser formulados como um ato direto com o uso do imperativo formal. Podemos afirmar que, em geral, os brasileiros da região sudeste do país evitam enunciados desse tipo, pois o emprego da forma imperativa representa uma atitude desprovida de polidez e, por isso, não são tão usadas na fala. No entanto, em placas e cartazes o seu uso é previsto e pressupõe uma formalidade maior, um distanciamento, uma consequente relação de assimetria de poder entre quem faz e recebe o pedido.

Assim sendo, por meio desses exemplos, podemos demonstrar a tendência cultural do brasileiro à evitação da incerteza de Hofstede (2010), pois nesses casos não é permitida a incerteza e a ambiguidade e se tenta evitar, por meio de instruções claras e impositivas, riscos e situações inesperadas. 


\section{Indiretos}

Nos exemplos abaixo vemos dois casos de indiretividade não convencional, constituídos de sentenças que não fazem referência ao ato em si, porém orientam o interlocutor por meio de pistas fortes (estratégia 8).

\section{ATENÇÃO}

SOM ALTO AQUI É JOGO SUJO

E26

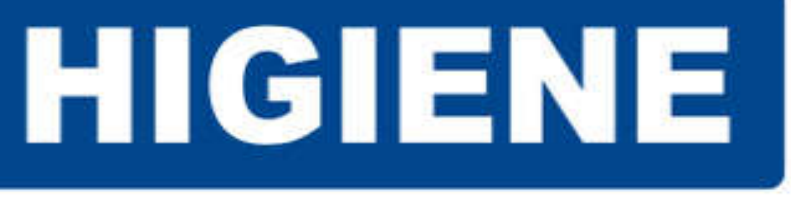

A LIMPEZA TRARÁ BENEFÍ́CIOS À TODOS.

E27

Considerando o tipo de perspectiva adotada pelos locutores ao elaborarem o pedido, encontramos duas orientações: no primeiro exemplo o locutor enfatiza seu próprio desejo ou exigência, orientando para si a perspectiva do pedido, enquanto no segundo exemplo temos uma perspectiva voltada para o nós, evitando o foco no agente ou no beneficiário. 
Temos nesses exemplos, assim como nos pedidos de estratégia direta (E23 e E24), placas feitas por particulares, ou seja, por profissionais especializados. Diferentemente dos pedidos já analisados, estes são linguisticamente econômicos, dispensando tudo o que seja acessório ao núcleo da mensagem (Pinto, 1990, p. 28).

No primeiro exemplo (E26), temos uma estratégia argumentativa que combina texto verbal e não verbal. Nesta ocorrência, o locutor faz referência parcial ao objeto necessário para realização do ato ("som alto"). Segundo Oliveira (1995), as pistas simulam reconhecimento da autonomia do outro. O solicitante pressupõe a capacidade do interlocutor de identificar a força pretendida do ato em função de um conhecimento linguístico e de mundo compartilhado. Ele então passa a responsabilidade de interpretação para o interlocutor, colocando-se a salvo do ato de imposição.

Assim sendo, espera-se que o interlocutor infira que é pelo discurso esportivo que a mensagem foi criada. Fazendo a alusão ao futebol, a placa com um cartão vermelho funciona como uma forma de resposta àqueles que colocam som alto sem levar em consideração os outros ao redor. O sentido do cartão vermelho na placa - que no futebol é usado para faltas graves - é reiterado, uma vez que o desacato à lei e a indiferença aos outros indivíduos são vistos como faltas graves.

No plano argumentativo, deparamo-nos com uso da expressão "jogo sujo"", cujo significado pode remeter tanto a corrupção, no contexto político, quanto a "jogo desleal, má conduta, infrações repetidas", no contexto esportivo. A apropriação do termo pelo contexto evidenciado não apenas cria uma aproximação dos significados com o fato em si, mas revela um aspecto cultural bastante significativo da cultura brasileira. Segundo Daolio, nosso cotidiano está impregnado de termos futebolísticos, tais como "pisar na bola", "fazer o meio de campo", "dar um chute", sendo utilizados pela população em geral, inclusive pelos torcedores menos fanáticos. $\mathrm{O}$ fato é que essas expressões foram incorporadas ao conjunto de itens lexicais do português do Brasil por sintetizar em poucas palavras o que se quer comunicar, tendo muito claro o significado no cotidiano de todas as pessoas (Daolio, 2006:142).

Este fato deve ser observado no ensino de línguas, pois, diferentemente do falante nativo, o aprendiz de PL2E pode não ter essa mesma percepção. O léxico vai sendo aos poucos adquirido pelo aprendente, e para conhecer o significado das palavras é preciso

\footnotetext{
${ }^{13}$ Disponível em: $<$ http://www.dicionarioolimpico.com.br/rugby-7s/cenario/jogo-sujo>. Acesso em: 15/07/19.
} 
também (re)conhecer o contexto cultural no qual elas se inserem, bem como as situações em que são usadas.

No exemplo (E27), por sua vez, encontramos um ato de fala que exprime pedido realizado por uma frase declarativa com o verbo no futuro do presente. De acordo com Searle (1975), os pedidos também podem ser realizados indiretamente, usando-se sentenças declarativas, em que não há qualquer referência ao ato a ser realizado ou a quem deveria fazêlo.

A nosso ver, o uso do futuro do presente em vez do imperativo no pedido ("A limpeza trará benefícios à todos.”), objetiva dar credibilidade à mensagem, que tem por finalidade convencer o outro a adotar determinada postura. Tradicionalmente, o emprego da forma verbal simplesmente se refere à ocorrência futura de uma situação (Castilho, 2016, p. 434). Nesse emprego particular, a situação a que se faz referência é inexistente no momento da enunciação, mas terá realização posterior a ele. Contudo, Cunha e Cintra (2008, p. 473), consideram que, além dessa função, o futuro do presente pode ainda ser empregado como uma "forma polida do presente" ou como uma "expressão de uma súplica, de um desejo, de uma ordem". Logo, seu uso pode também ter uma acepção imperativa.

Ao direcionar nossa reflexão para os aspectos culturais que regem o uso de placas e cartazes com a finalidade de manter a disciplina em diferentes espaços sociais, vemos claramente que uma das lógicas que comandam as relações sociais no Brasil é o da mediação. $\mathrm{O}$ fato de os brasileiros possuírem um alto índice de aversão à incerteza, conforme propõe Hofstede (2010), é um elemento que desperta a necessidade de possuírem mais controles para a estruturação da vida, visando um ambiente mais seguro e com menos incertezas para se viver. Entretanto, apesar dessa tendência característica da sociedade brasileira, em geral, culturalmente parece haver certo prazer em ditar normas que muitas vezes não são cumpridas. Nossos dados sugerem que somos um povo onde o que nos rege são as proibições. A lei que em geral significa "não pode"; na prática, significa "depende", o que nos leva a criar ainda mais regras adicionais e aperfeiçoar as formas de burlar a lei.

\section{6}

\section{Ironia}

Segundo o dicionário online de língua portuguesa, ironia é uma "figura de linguagem pela qual se expressa exatamente o oposto daquilo que se diz; A utilização dessa figura é feita 
com o objetivo de produzir ou salientar alguns aspectos de caráter humorístico" ${ }^{14}$. Sendo sinônimo de sarcasmo e sátira, a ironia é muito utilizada para subverter situações sérias de modo a lhes conferir caráter cômico, usando-se de personalidades de destaque na mídia e de situações cotidianas, dentre outras para provocar o riso. A ironia, porém, necessita de um préconhecimento do outro a fim de entender o sentido da comicidade imposta, ou esta passará despercebida.

No que se refere ao ensino de segundas línguas, o conhecimento compartilhado é fundamental para a compreensão da crítica, do humor e da ironia presentes em várias situações comunicativas. A percepção e a compreensão do humor estão diretamente ligadas a questões de ordem cultural e essa questão é fundamental no ensino de línguas estrangeiras.

Vejamos como esses aspectos acontecem nas placas e cartazes não oficiais no Brasil.

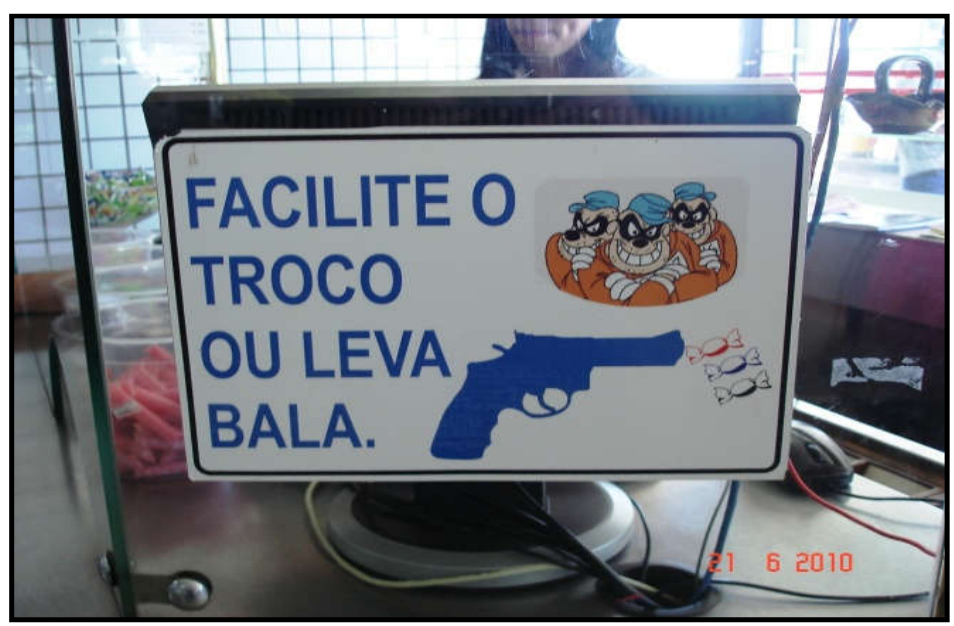

E28

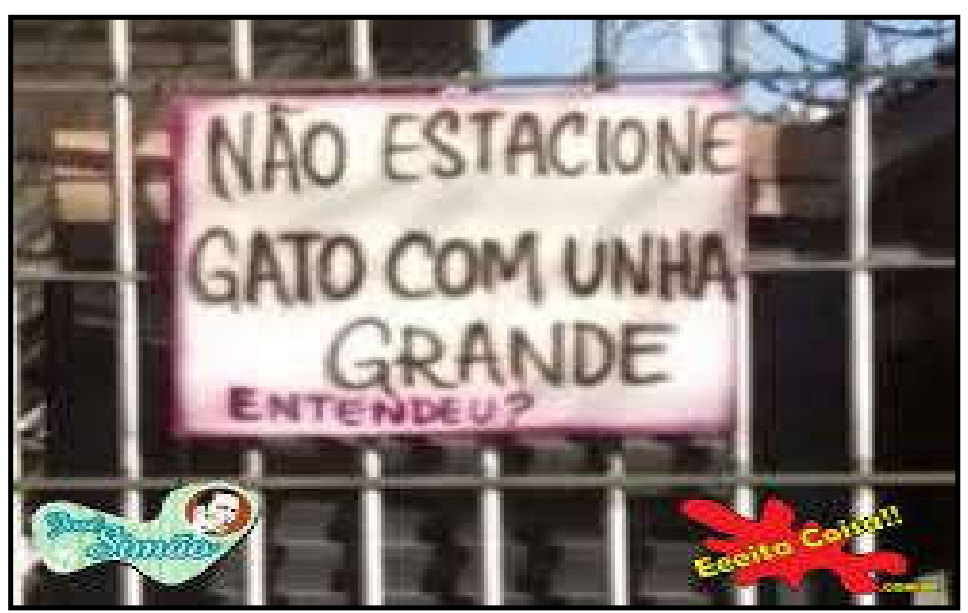

E29

\footnotetext{
${ }^{14}$ Disponível em: < http://www.dicio.com.br/ironia/>. Acesso em: 15/07/19.
} 
As amostras acima denotam o tipo de estratégia modo derivável nos atos principais. A perspectiva do pedido está orientada para locutor (eu).

Como pudemos constatar até aqui, a persuasão tem grande relevância nos textos registrados em placas e cartazes, visto que seu objetivo visa levar o interlocutor a fazer algo. Uma das estratégias utilizadas pelos solicitantes para chamar a atenção dos interlocutores é o uso da ironia como um recurso argumentativo.

Não é difícil perceber que os pedidos elaborados com tal recurso não se dão totalmente de forma transparente, pois para serem compreendidos necessitam que o leitor faça alusões e identifique os implícitos que estão presentes no discurso, bem como os sentidos que eles carregam.

Assim, ao analisar os pedidos desta categoria, encontramos, em E28, um pedido muito comum em estabelecimentos comerciais não muito sofisticados, sendo direcionado ao público consumidor desses espaços. Neste pedido percebemos a presença de dois tipos de texto: o verbal e o não verbal. Em relação ao primeiro, podemos dividi-lo em duas partes: o ato principal "Facilite o troco", realizado de com o verbo no imperativo formal, e o ato de apoio "Leva bala", que traz uma mensagem implícita, encoberta, dificilmente compreendida pelos falantes não nativos. É importante ressaltar que, em muitos estabelecimentos comerciais no Brasil, é comum oferecer ao comprador algumas balas (doces) no lugar do troco em moedas que deveria ser dado.

Por outro lado, no português brasileiro, essa combinação do verbo levar + o substantivo bala pode ser substituída, sem comprometimento de sentido, por "ser atingido por um tiro". Nesse caso, temos apenas uma expressão para duas situações distintas e bastante específicas. O solicitante, valendo-se dessa diferença, usa o sentido mais ameaçador da expressão ("levar um tiro") para criar um efeito de persuasão sobre o interlocutor e convencêlo a facilitar o troco. O uso das ilustrações como atos de apoio reforça esse valor. A imagem das balas saindo da arma demonstra o que o locutor pretende fazer caso o pagamento não seja facilitado, ou seja, caso o cliente não pague com o valor aproximado do produto consumido. Acima dessa imagem, temos, ainda, a malícia estampada na face dos personagens Irmãos Metralha da Disney, enfatizando a ação a ser feita, ao mesmo tempo em que o pedido é reforçado.

Essa mensagem para um brasileiro é simples e pode nem ser considerada como ameaçadora, quando entendida a palavra bala como doce, mas, para um estrangeiro, ainda assim a mensagem pode representar uma provocação, uma afronta incabível, visto que deveria ser obrigação do estabelecimento garantir o troco aos seus clientes. Em sociedades onde essa 
prática é incomum, o efeito irônico perde-se totalmente, não se percebendo a ironia, o texto torna-se ininteligível em todos os sentidos.

Vemos então que o não entendimento do enunciado corrobora o entendimento do papel da cultura na compreensão do efeito irônico. O costume de pedir para facilitar o troco ao efetivar o pagamento de uma compra revela não só a necessidade de o solicitante ter troco, mas aponta o problema de circulação de moedas no Brasil, visto que o brasileiro tem efetuado mais pagamentos no cartão ou tem o hábito de guardá-las em cofres ${ }^{15}$. A ausência de troco, portanto, se tornou um problema generalizado no país, embora esta informação não esteja explícita nos enunciados de placas e cartazes.

Ao citar DaMatta, Le Berre (2007, p. 65) aponta que

\begin{abstract}
a informalidade é uma marca peculiar da maioria das relações da sociedade brasileira, tanto no domínio da casa, quanto no domínio da rua. Embora haja profundas desigualdades sociais no Brasil e um sistema hierarquizado, a lógica da estrutura das relações sociais permite e estimula a existência de tal nível de informalidade, quer seja entre superiores e inferiores, quer seja entre desconhecidos.
\end{abstract}

Em E29, por sua vez, encontramos um aviso afixado em um portão de garagem. $\mathrm{O}$ ato principal é constituído de um pedido direto, formado de imperativo negativo "Não estacione". No português do Brasil, utilizamos, em placas e cartazes, inúmeras expressões desse tipo para exprimir o valor de proibição, tais como "Não fume", "Não buzine", "Não entre", "Não bater na porta".

Nessa ocorrência, podemos perceber que o ato de apoio, "Gato com unha grande", apresenta uma ameaça implícita, que se dá visando à correção de uma atitude indesejável muito comum nas ruas da cidade do Brasil. Um falante nativo, dotado de intuição linguística, saberá que o gato mencionado pelo locutor pode até existir, porém não é ao animal que ele se refere, mas sim a ele próprio, morador da casa, que, caso tenha seu direito desrespeitado, fará “justiça com as próprias mãos"16.

A ameaça favorece a ironia nesse texto por assemelhar nesse texto, não duas ideias contraditórias ou diferentes, mas duas classes oposta de seres.

\footnotetext{
15 Disponível em: <https://www.otempo.com.br/capa/economia/dar-bala-e-arredondar-troco-e-ilegal-mas ninguem-recorre-1.235565 > . Acesso em: 15/07/19.

${ }^{16}$ Punição dada por uma pessoa ou grupo de pessoas sem cumprimento da lei, e baseada em opiniões próprias, com o objetivo de vingança. Disponível em:

$<$ https://www.dicionarioinformal.com.br/fazer\%20justi\%C3\%A7a\%20com\%20as $\% 20 \mathrm{pr} \% \mathrm{C} 3 \% \mathrm{~B} 3$ prias $\% 20 \mathrm{~m} \%$

3\%A3os//>. Acesso em: 15/07/19.
} 
Ainda neste aviso, podemos destacar o uso da expressão de consulta "Entendeu?" para encerrar o aviso. No português falado do Brasil, é comum utilizarmos elementos tais como “né?, sabe?, viu?, ok?, ce viu?” para expressar uma nítida orientação por parte do falante em direção ao ouvinte, com o intuito de buscar uma aprovação discursiva (Guerra, 2007, p. 62). Segundo Blum-Kulka (et al., 1989) tais expressões podem contribuir para aumentar o efeito de polidez ao realizar um pedido ou uma ordem, pois servem para envolver o interlocutor consultando sua opinião sobre determinado tema.

\section{Indiretos}

Considerando os pedidos diretivos indiretos da categoria ironia, classificamos os pedidos selecionados como indiretos convencionais, porém atribuímos essa indiretividade aos atos de apoio e não aos atos principais, conforme se espera das classificações de estratégia de pedidos propostas por Blum-Kulka e Olshtain (1984). Apesar disso, optamos por manter a nomeação dada aos pedidos propriamente ditos também aos atos de apoio.

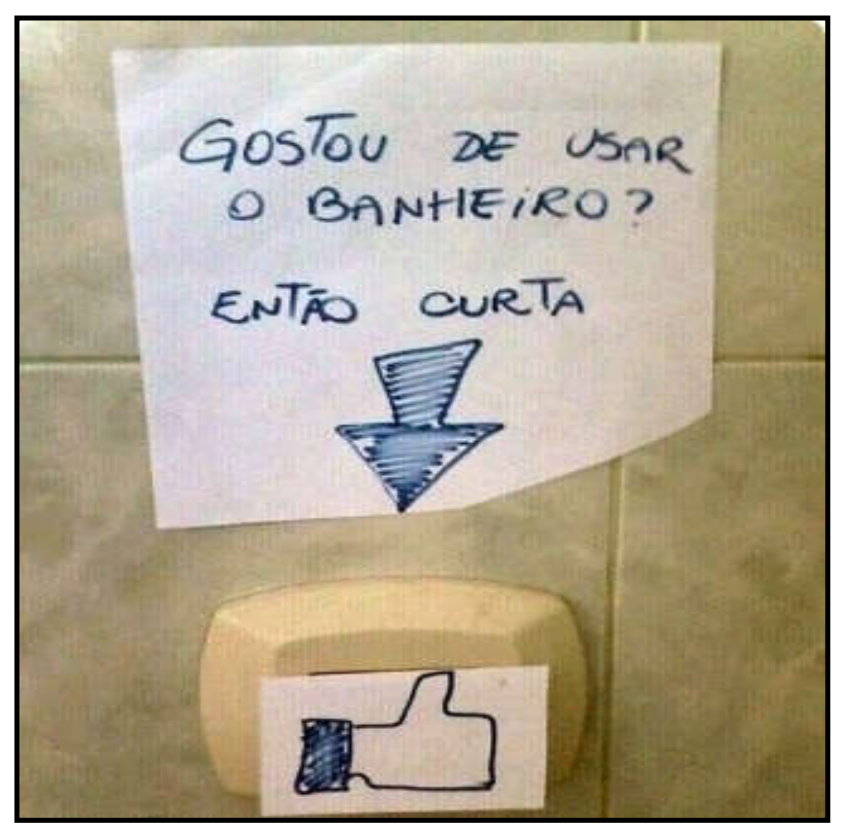

E30 


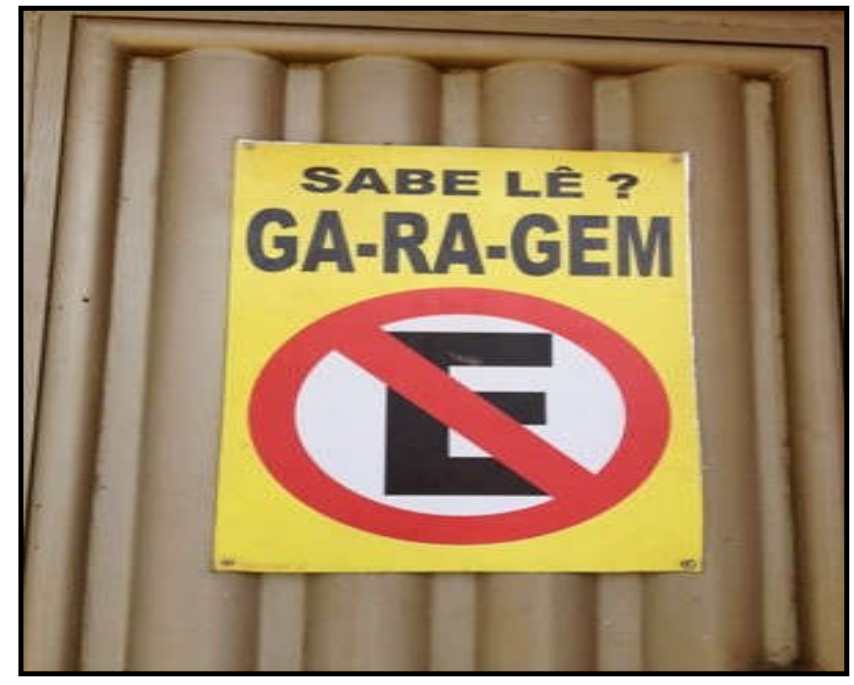

E31

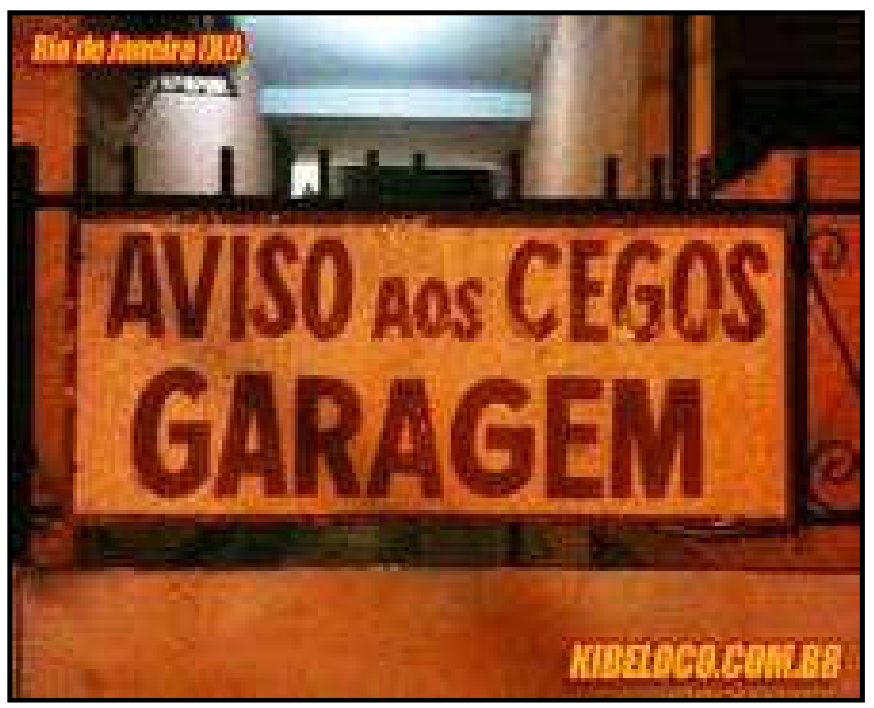

E32

De acordo com Brown e Levinson (1987), as estratégias encobertas permitem que o falante faça o FTA sem ter que se responsabilizar por ele, deixando que o interlocutor decida como interpretar o ato de fala, assim como ilustra o ato de apoio em E30, "Gostou de usar o banheiro?", que funciona como um pré-pedido para que o interlocutor cumpra o pedido enunciado no ato principal "Então curta".

O pré-pedido é um pré-anúncio e tem a função de conseguir a colaboração do ouvinte para a realização do pedido. É importante considerar que, embora o locutor tenha utilizado o pré-pedido como estratégia de polidez negativa, o ato principal é feito de forma direta, com o verbo no imperativo, o que evidencia o desejo de cumprimento do ato. 
Observamos também o uso do gesto com o polegar positivo para cima, recurso popular nas mídias sociais para afirmar algo, concordar ou dar um simples "ok", e que na cultura brasileira também tem um valor positivo nas interações sociais.

É preciso atentar, porém, que, apesar de ser um gesto que marque um trato informal e amável do brasileiro, seu uso em outras culturas pode ter outras concepções. Roger Axtell (1995), em seu livro “Gestos”, afirma:

Levantar o polegar, que pode indicar no Brasil: "está tudo bem", na Europa significa pedido de carona, no Japão indica o número cinco, na Alemanha, o número um, na Austrália e Nigéria, é considerado um gesto obsceno e na Turquia, convite para um encontro homossexual. (...) Uma cabeleireira paulista em visita ao Japão descobriu que levantar o polegar para um rapaz solteiro significa perguntar se ele tem namorada e o rapaz vai deduzir que a moça deseja sair com ele. Já o músico Alberto Marsicano aprendeu, na Índia, um oitavo significado para esse gesto. Quando certa vez foi a Calcutá, levou várias camisas da seleção brasileira para trocar por seda. Depois de acertar a troca, quase foi tudo por água abaixo, porque ele levantou o polegar e o comerciante ficou muito bravo, fechou a cara, pensando que era sinal de desistência do negócio. (Idem, p. 6)

Em contrapartida, em E31, temos um pedido que não está todo na forma indireta. Nessa ocorrência, o locutor, primeiramente, realiza uma estratégia preparatória (“Sabe lê?”) para a realização da solicitação. Como podemos ver, o locutor afronta o interlocutor, colocando em cheque a sua habilidade de saber ler, associando a esse fato o motivo pelo qual ocorre a má conduta. Desse modo, o solicitante não deseja obter uma resposta "sim ou não", pois já sabe a resposta. Na verdade, a intenção é chamar atenção para a situação incoveniente criada pelo interlocutor, realizando a depreciação do próprio para conseguir o cumprimento do pedido. A soletração da palavra "GA-RA-GEM" enfatiza a hostilidade do solicitante.

Sendo o português uma língua de alto contexto (Hall \& Hall, 1990), fica claro a partir dessas considerações que há no enunciado linguístico muito mais a ser transmitido. Assim, podemos constatar no exemplo que não há muita informação inserida na mensagem escrita; o não dito precisa ser inferido no contexto e pelo sinal de "proibido estacionar".

Em E32, também temos um aviso afixado diante de uma garagem. Assim como no aviso anterior, temos um propósito de elaboração que permite uma abordagem diferente para o mesmo discurso, ou seja, "Não Estacione". Nesta ocorrência, o pedido é constituído pelo ato de apoio "Aviso aos cegos" e pelo ato principal "Garagem". Nesta ocorrência, vemos o deslocamento da palavra "cego", usada para caracterizar pessoas privadas de visão, para fazer referência àquelas pessoas que fingem não estar vendo que determinado local é inapropriado 
para estacionar. Assim, a ironia não despreza o sentido literal da palavra, mas a incorpora ao que não foi dito para chamar a atenção do seu interlocutor.

A partir dos exemplos, percebemos que esses avisos camuflam intenções e veiculam identidades e padrões culturais de comportamento dos brasileiros. Dentre eles, revelam que, ao contrário do que postula Hofstede (1997), podemos ser também uma sociedade individualista, não atuando de acordo com o interesse do grupo, mas em benefício próprio.

Faz-se necessário dizer que, apesar de o humor não ser um dos elementos de análise desta pesquisa, é importante registrar que a sua presença perpassa as categorias aqui observadas. Por meio do seu uso é possível suavizar a gravidade das questões abordadas, aproximando-as da realidade, sem julgamentos ou condenações morais sobre as pessoas envolvidas ou sobre as suas ações. Além disso, a situação cômica favorece a emergência da crítica e chama a atenção do leitor para detalhes que lhe poderiam passar despercebidos.

No entanto, a percepção e a compreensão do humor, como aponta Mejlachowicz (2017), estão diretamente ligadas a aspectos de ordem cultural e essa questão é relevante no ensino de línguas estrangeiras, pois trata-se de um elemento que depende muitas vezes não só de conhecimentos linguísticos, mas também de um entendimento mais apurado da sociedade em que a língua é falada.

O humor seria então um elemento significativo para se entender uma determinada cultura, tendo, portanto, nos enunciados em placas e cartazes não oficiais elementos fecundos para fomentar a discussão de temas importantes. 


\section{Outros atenuantes lexicais e gramaticais}

Os atos ilocucionários que dão conta dos atos de pedir em placas e cartazes não oficiais no português do Brasil são classificados por nós, de acordo com a proposta de Searle (2002), em diretivos, tipos de enunciados em que se tenta levar o outro a fazer algo. Os mesmos podem se manifestar na forma diretiva direta ou indireta, levando em conta ainda a divisão deste último em convencionais e não convencionais conforme estabelecido por BlumKulka e Olshtain (1984) e Brown \& Levinson (1987).

Além das estratégias citadas, utilizamos também os atenuantes lexicais e gramaticais (Blum-Kulka e Olshtain, 1984), tais como: o uso de endereçamento, saudações, justificativas, elogios; o uso das expressões como "por favor" e "obrigada", entre outras, além do uso de sentenças interrogativas e construções impessoais. Quanto às estratégias que reforçam a força impositiva do ato, consideramos os elementos agravadores, que incluem insultos, ameaças e expressões de insatisfação.

O modelo proposto por Brown e Levinson (1987) enfatiza os aspectos relativos à harmonia interacional, partindo do princípio de que os falantes tendem a evitar o conflito a qualquer custo. No entanto, é preciso considerar que há ocasiões sociais diversas em que os falantes não pretendem resguardar a imagem do outro e, muitas vezes, nem mesmo a própria. Desse modo, é de grande relevância destacar as estratégias impositivas também em nossos dados.

Sendo assim, para facilitar a aprendizagem dos alunos na identificação e na combinação das estruturas adequadas utilizadas nos pedidos - com o objetivo de estabelecer uma interação eficaz - propomos, na seção seguinte, a descrição dos elementos que compõem esse ato de fala ilocucionário.

\section{1}

\section{Estrutura do ato ilocucionário dos atos de pedir em placas e cartazes não oficiais}

Em nossa pesquisa foi identificado que atos de fala de pedidos em placas e cartazes podem ser constituídos de um só segmento (núcleo) ou de vários segmentos (núcleo acompanhado de outras partes). Vejamos a seguir: 
a. Ato principal: unidade mínima que realiza o pedido; parte onde está contida a essência do ato (núcleo).

b. Alertas: saudações, cumprimentos ou chamamentos (verbais e não verbais).

c. Marcadores de polidez e de indiretividade: elementos que servem de atenuantes, ou mitigadores em situações impositivas e de confronto de faces.

d. Ato de apoio: pré-pedido ou unidades externas ao pedido que servem para modificar seu impacto, atenuar ou intensificar a força do enunciado.

De acordo com os nossos dados, os pedidos em placas e cartazes podem apresentar-se da seguinte forma:

\subsection{1}

\section{A partir do ato principal exclusivamente}

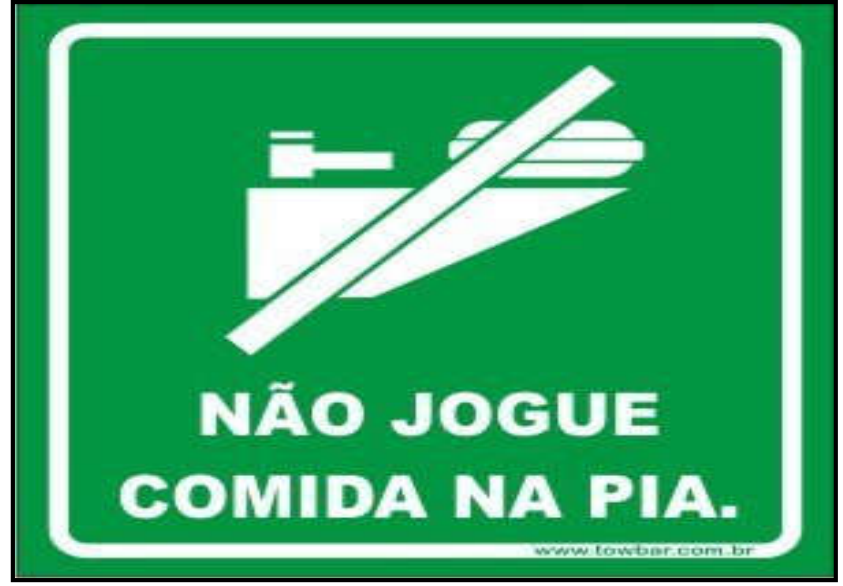

E33

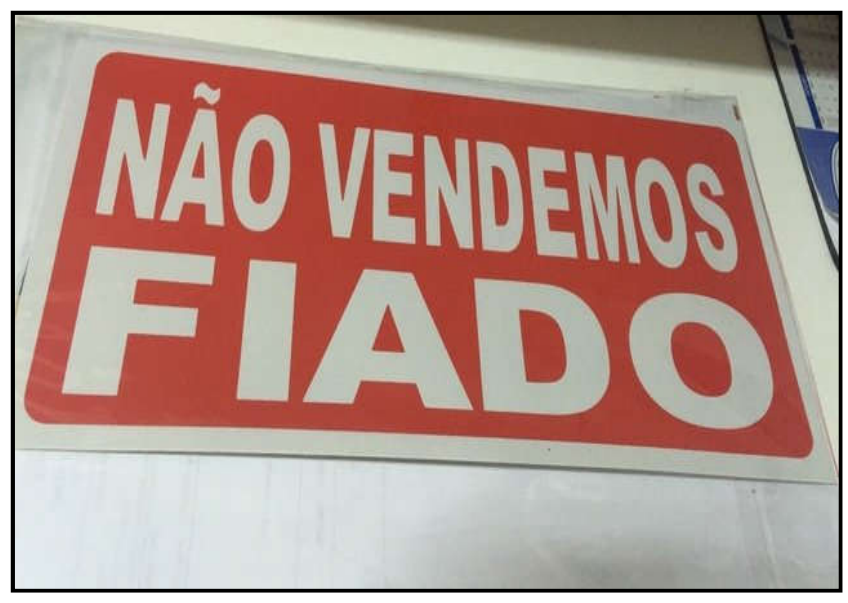

E34 


\section{1 .2}

A partir de título + ato principal

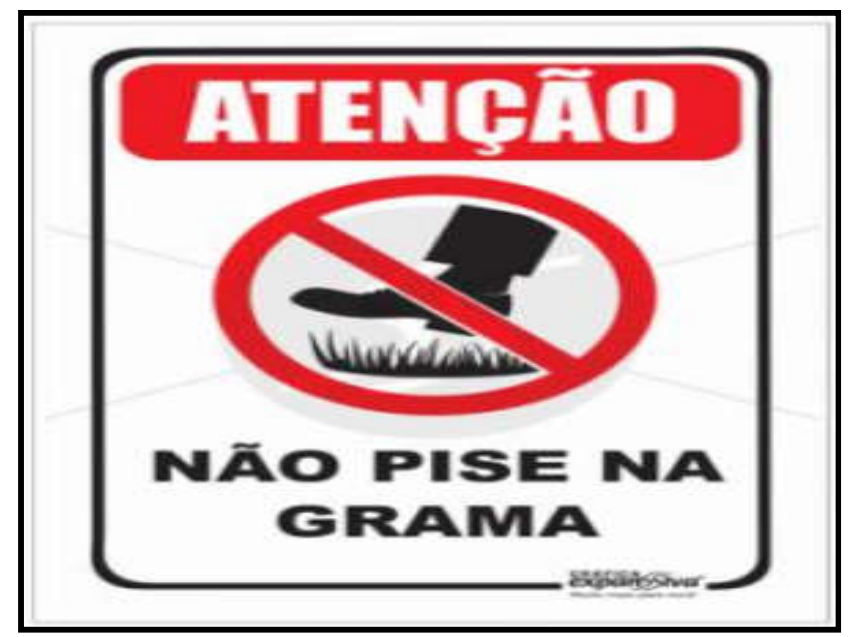

E35

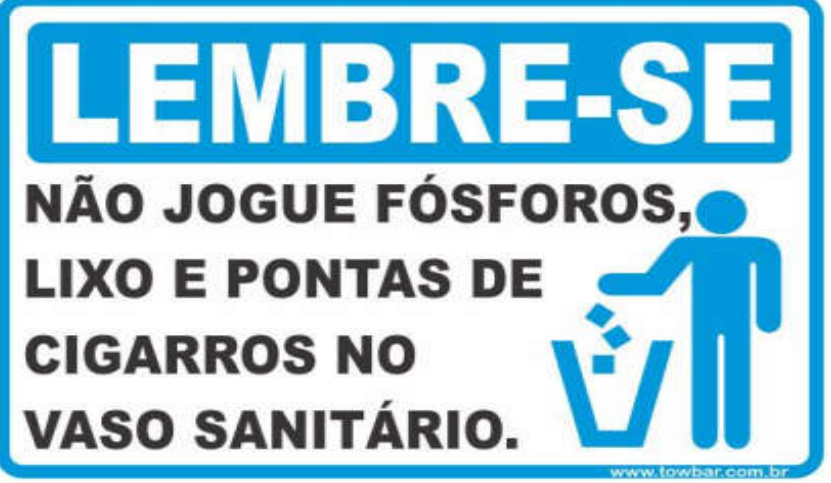

E36

\section{1 .3}

A partir de marcadores de polidez cristalizados + ato principal

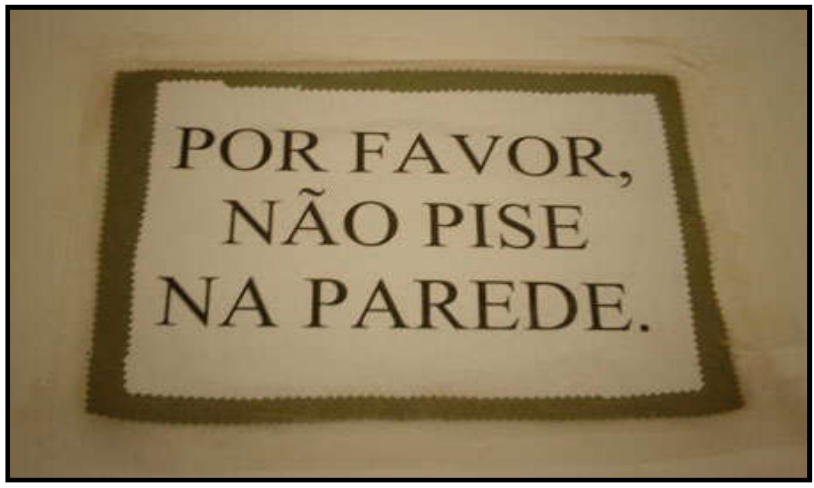




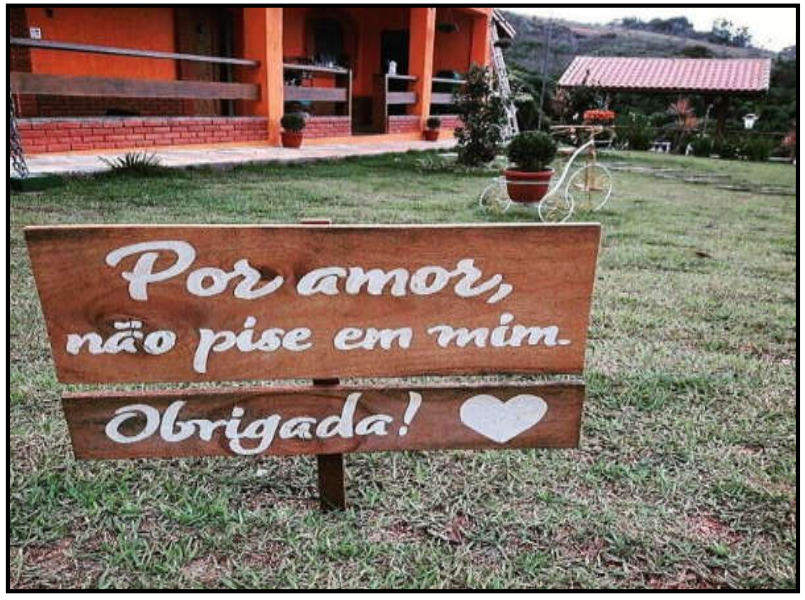

E38

6.1.4

A partir de cumprimento e/ou chamamento, e/ ou saudações + ato principal

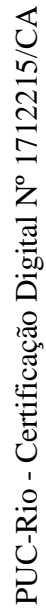

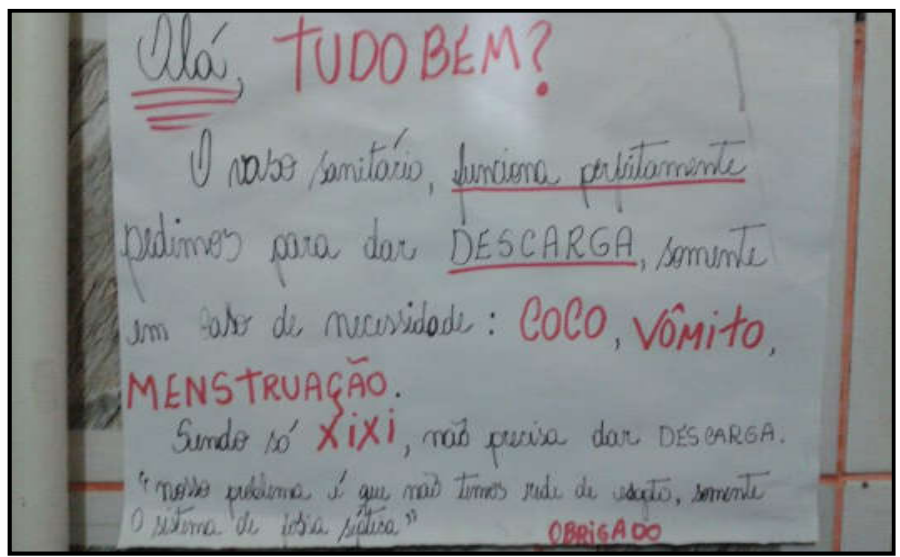

E39

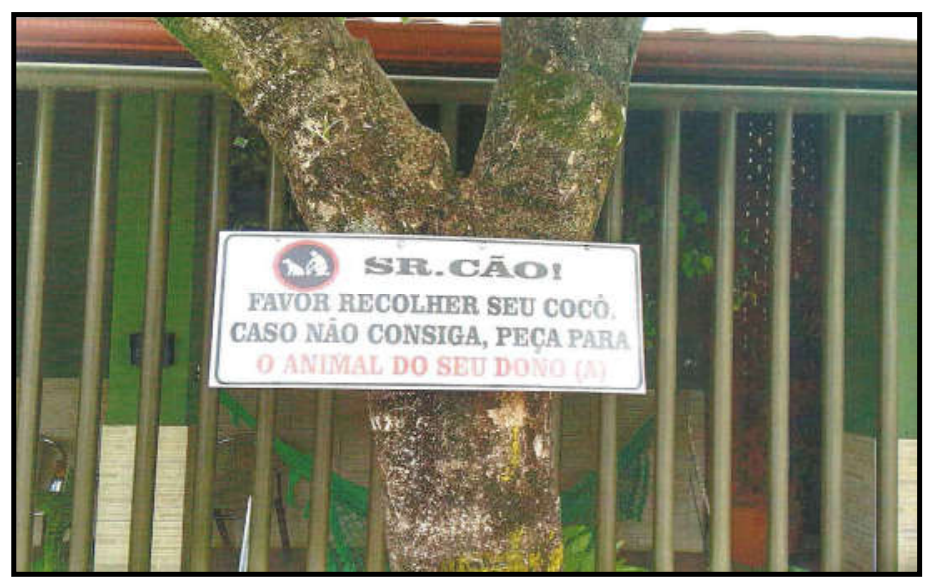

E40 
6.1.5

Sentenças interrogativas

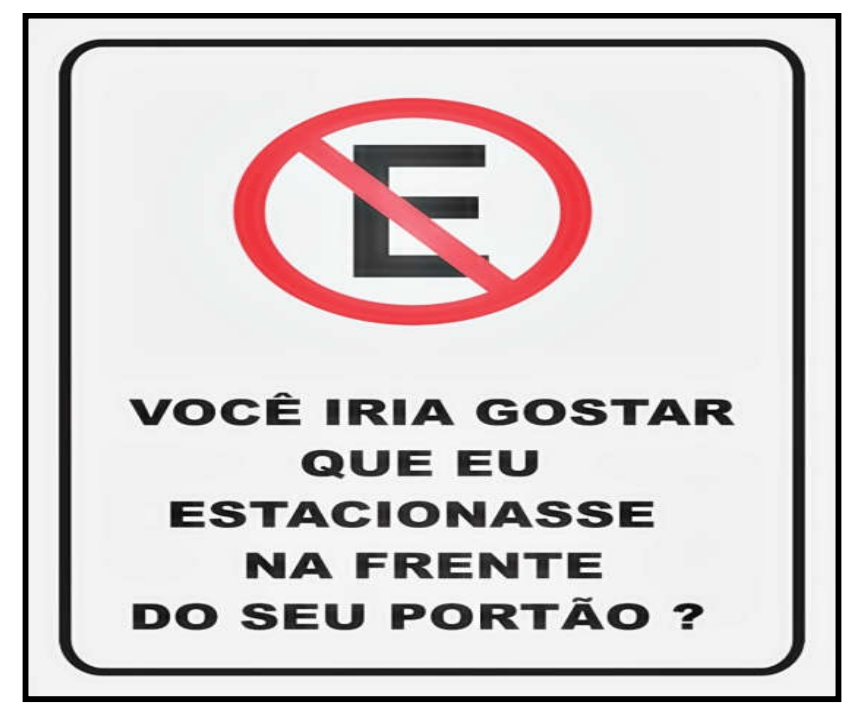

E41

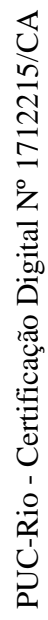

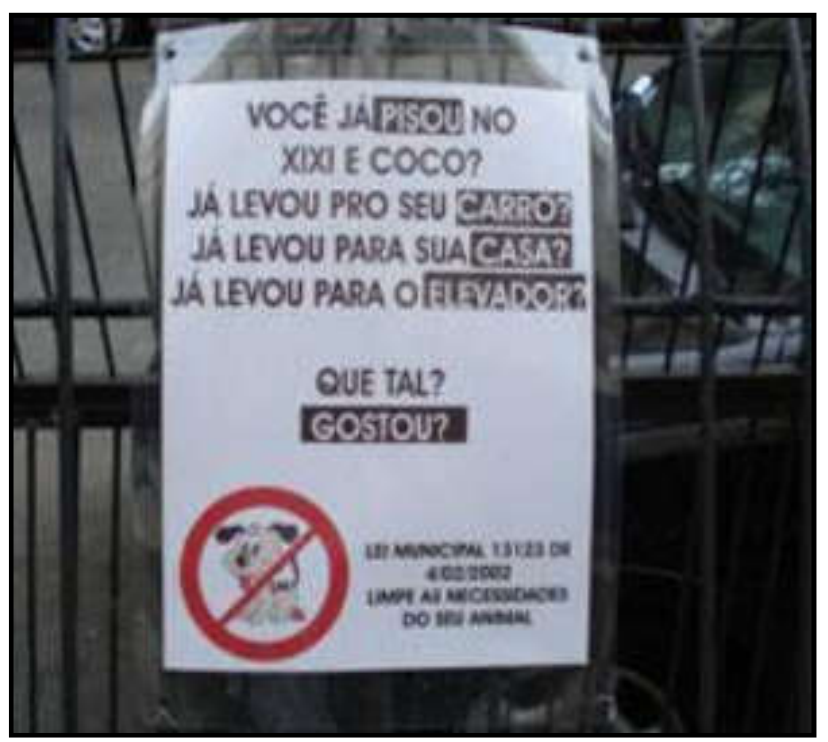

E42 


\subsection{6}

\section{Ato(s) principal(is) + justificativa}

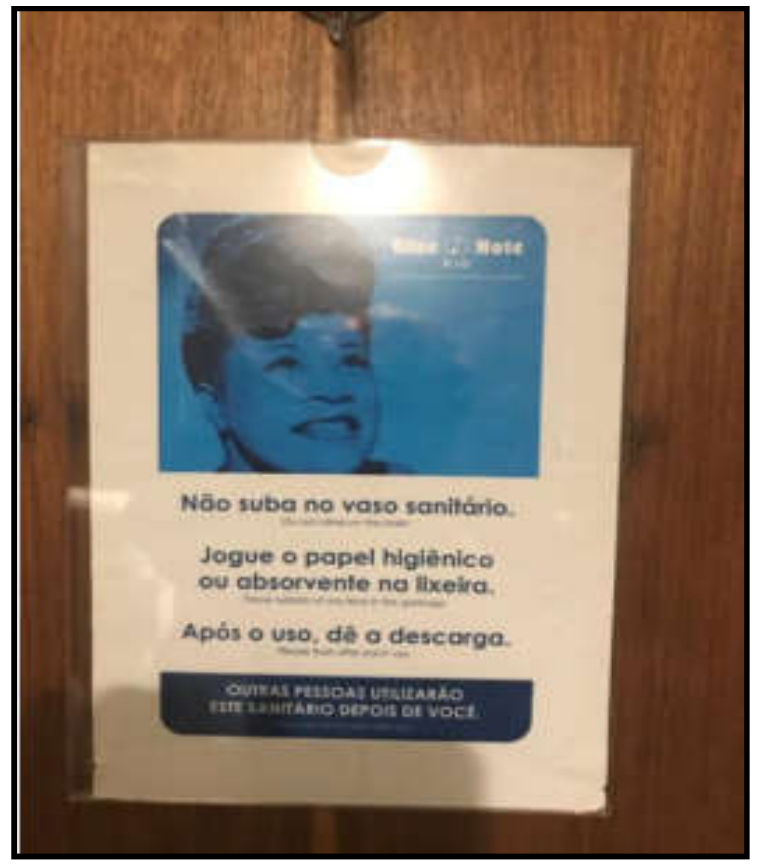

E43

Vimos, aqui, muitas formas utilizadas pelo solicitante, formas essas que ilustram as estruturas presentes em pedidos de boas condutas em nossa língua. Porém, sabemos que os exemplos dados não dão conta da totalidade de estratégias adotadas pelos falantes do português do Brasil. Mas por outro lado, os modelos apresentados podem servir como material de base para o ensino de tais estratégias.

Com o objetivo de facilitar o trabalho do professor de PL2E em sala de aula, apresentamos, a seguir, dois quadros com as principais estratégias utilizadas pelos solicitantes para atenuar ou reforçar o teor de imposição dos atos de pedir em placas e cartazes não oficiais de acordo com o resultado final de nossa análise.

\section{2}

\section{Estratégias que atenuam ou reforçam o teor de imposição dos atos diretivos}

O conjunto de estratégias utilizadas pelo brasileiro para construir as mensagens que expressam pedidos em placas e avisos pode ser apresentada aos aprendentes de PL2E de 
forma didática. Sendo assim, o quadro abaixo é uma proposta de organização desses atos de fala, a partir de uma possível subcategorização para as diferentes construções linguísticas encontradas no nosso corpus.

Dessa forma, apresentamos, a seguir, as principais estratégias que 1) atenuam e 2) reforçam uma imposição implicada nos atos de pedir analisados no gênero textual por nós analisado nesta pesquisa.

\subsection{1}

\section{Estratégias que atenuam o teor da imposição}

\begin{tabular}{|l|l|}
\hline \multicolumn{1}{|c|}{ SUBCATEGORIA } & \multicolumn{1}{c|}{ EXEMPLO } \\
\hline Fórmulas de assentimento & \multicolumn{1}{c|}{ Gostou de usar o banheiro? } \\
\hline Indicação do beneficiário & Prezados clientes, meu querido, meu amor, etc. \\
\hline Vocativos & $\begin{array}{l}\text { Você iria gostar que eu estacionasse em frente } \\
\text { ao seu portão? }\end{array}$ \\
\hline Fórmulas interrogativas & (...) A minha coluna não está mais aguentando. \\
\hline Justificativa & \multicolumn{1}{c}{ por favor, obrigada } \\
\hline Expressões cristalizadas de polidez & \\
\hline
\end{tabular}




\section{2 .2}

\section{Estratégias que reforçam a imposição}

\begin{tabular}{|c|c|}
\hline SUBCATEGORIA & EXEMPLO \\
\hline Repreensão & $\begin{array}{l}\text { Reflita sobre seu comportamento aqui; } \\
\text { (...) Não tenha comportamento de um suíno. }\end{array}$ \\
\hline Imperativo & $\begin{array}{c}\text { Não estacione; } \\
\text { Não suba no vaso sanitário. }\end{array}$ \\
\hline Agravadores & $\begin{array}{c}\text { Filho de uma puta; seu merda; aviso aos } \\
\text { idiotas. }\end{array}$ \\
\hline Ameaça & $\begin{array}{l}\text { Intrusos vão levar chumbo!; } \\
\text { Vai tomar porrada. }\end{array}$ \\
\hline Reforço da ordem anterior & Entendeu ou preciso desenhar. \\
\hline
\end{tabular}

Acreditamos que os quadros acima sugeridos podem contribuir de forma efetiva para a elaboração de material didático e/ou de aulas que possam explorar de forma construtiva a compreensão do gênero aviso, a partir do trabalho realizado com placas e cartazes não oficiais encontrados em diferentes pontos da cidade.

A seguir, apresentamos nossas considerações finais sobre toda a pesquisa aqui empreendida. 


\section{Considerações finais}

O estudo dos atos de fala que expressam pedidos, em placas e cartazes não oficiais, demonstrou-se desafiador e instigante durante todo o processo desta pesquisa. Uma vez que o fenômeno de lembretes e avisos como forma de prevenir, coibir ou estimular uma diversidade de comportamentos apresenta muito pouca descrição e análise, sobretudo, no que tange aos objetivos relacionados ao ensino de PL2E, este estudo descortinou a possibilidade de se abordarem a língua e a cultura brasileira por um ângulo ainda pouco explorado.

Tornou-se, portanto, fundamental, ao se desenvolver esse tema, assumir uma perspectiva de estranhamento em relação ao objeto de estudo, de modo a possibilitar a descrição das regras subtendidas em cada tipo de situação enunciativa representada nas placas e cartazes não oficiais.

Mas, para além do não dito, este estudo se propôs a unir os aspectos linguísticos aos aspectos culturais, presentes nos pedidos orientados para uma boa conduta, visando uma aplicabilidade ao ensino de PL2E. Para tanto, o presente trabalho teve como objetivo descrever as estratégias de elaboração de pedidos empregados por diferentes brasileiros "com vista à comunicação com o público, um público indiferenciado, constituído por passantes ocasionais" (Pinto, 1990, p. 28). Ao contemplarmos tais atos de fala, damos relevância em especial à compreensão da escrita, prática que consideramos essencial para que o aprendiz de L2 compreenda de forma eficiente os variados dizeres e apelos presentes nos contextos do dia a dia do brasileiro.

Para mostrar as diversas possibilidades de elaboração de um pedido em nossa língua, fizemos uso, neste trabalho, de uma abordagem interdisciplinar que compreende tanto os aspectos linguísticos quanto os aspectos culturais de nossa sociedade. Com base na Teoria dos Atos de Fala e na Sociolinguística Interacional, descrevemos as construções presentes nos atos de fala de pedir veiculados em placas e cartazes, bem como as estratégias de polidez e mitigação peculiares a nossa cultura, tais como indiretividade e as expressões cristalizadas de polidez.

Uma vez que o nosso propósito não era apenas descrever a estrutura verbal dos pedidos, mas também realçar os aspectos culturais neles subjacentes, os conceitos da Antropologia Social foram fundamentais para que fosse associado à forma da língua o seu uso, ou seja, os seus aspectos verbais aos não verbais. 
De expressiva importância também para este trabalho foi a corrente teórica do Interculturalismo, que nos mostra a necessidade de compreendermos os padrões de comportamento, as crenças e os valores do grupo com o qual entramos em contato, para que a comunicação e o convívio entre os indivíduos sejam harmoniosos e ocorram de modo satisfatório.

Com auxílio dessa fundamentação interdisciplinar, pudemos pontuar, inicialmente, que as práticas de preservação da face utilizadas pelos solicitantes podem ocorrer tanto no ato principal, como nas sequências que precedem ou sucedem o ato de pedir (pré-pedido e justificativa). Dentre os tipos de estratégias que atenuam o ato de ameaça à face (AAF) e que ocorrem no ato principal, destacamos a indiretividade convencional e não convencional; a utilização de fórmulas de assentimento; a indicação do beneficiário; as expressões cristalizadas de polidez; as justificativas, e o uso de vocativos que denotam afeto. Constatamos também que são frequentes em placas e cartazes os atos de pedir indiretos, ou seja, atos que aparentam ser outros atos e funcionam como atenuadores dos atos ameaçadores de face. Desse modo, constatamos a necessidade de se diferenciar a estrutura formal dos atos diretivos. Dentre os procedimentos atenuadores, externos ao ato principal, destacamos o uso de vocativos, as justificativas, as expressões cristalizadas de polidez e as fórmulas interrogativas.

Identificamos também, em nossos dados, estratégias que enfatizam o teor de imposição do pedido. Dentre os elementos agravadores que apareceram no ato principal, destacamos: o uso do tempo verbal imperativo, a repreensão e os elementos lexicais que denotam impaciência (ex: "seu merda", "filho de uma puta"). Dentre as estratégias agravadoras, externas ao ato principal, destacamos a ameaça explícita ao interlocutor (“Intrusos vão levar chumbo") e a reiteração da ordem ("Entendeu ou preciso desenhar”).

Além do mais, percebemos que a escolha das construções e dos procedimentos que reforçam ou atenuam o ato de imposição está condicionada ao contexto e à intenção do solicitante em ser mais ou menos direto. Constatamos que as construções dos atos diretivos, além de refletirem experiências repetitivas e desagradáveis, podem influenciar a reação dos interlocutores ao ato solicitado.

Com base nos dados, percebemos que há uma preferência, nos enunciados veiculados em placas e cartazes, pela diretividade, mais especificamente pelo tipo mais direto (pedidos deriváveis de modo). Apesar de, na oralidade, o brasileiro evitar enunciados com o emprego da forma imperativa, seu uso para dar conselhos e instruções parece ser muito utilizado para 
enfatizar a ação e eliminar possíveis ambiguidades na elaboração dos atos de fala de ordem e pedidos.

A ocorrência de pedidos diretos em nossos dados, mesmo nos pedidos classificados como indiretos, demonstrou que diretividade não necessariamente implica menor polidez ou ausência de polidez: o uso do imperativo acompanhado de elementos atenuadores, por exemplo, contribuiu para a redução da imposição dos pedidos diretos e para o desejo de manutenção de face, conforme podemos constatar nas categorias cordialidade e apelo. Entretanto, nas categorias de agressividade e ameaça, a combinação desse modo verbal com estratégias agravantes reforçou o sentido de imposição por parte do locutor, demonstrando não haver nenhuma preocupação em manter a sua face positiva e nem a face negativa do interlocutor. Nesses casos, verificamos que há insatisfação, e os aborrecimentos nas situações comunicativas evidenciadas abriram espaço para um tratamento linguístico baseado no confronto, seja ele na forma direta ou indireta.

Da mesma forma como constatamos que a diretividade não pode ser considerada sinônimo de falta de polidez, após a análise das estratégias de pedidos indiretos, compreendemos que a indiretividade também nem sempre está associada a um maior grau de polidez. Conforme pressupõem Brown e Levinson (1987), uma das razões de se optar por estratégias indiretas é parecer não impositivo, satisfazendo tanto a face negativa do interlocutor, quanto a face positiva do locutor. No entanto, podemos verificar que não há necessariamente uma ligação direta entre o uso de estratégias indiretas e uma conduta que demonstre maior cuidado com a preservação da face do outro. Nos casos analisados na categoria agressividade, por exemplo, por meio de uma estratégia indireta, os solicitantes ameaçaram a face positiva dos seus interlocutores ao utilizar imagens pejorativas e elaborar enunciados hostis.

Pudemos também constatar, pela análise, a preferência pela perspectiva do locutor, resultante do próprio fato de esses pedidos serem fruto de interesses pessoais para alcançar o que se pretende. Em alguns casos, vimos também que os pedidos estavam voltados para o atendimento do grupo; estes avisos estavam inseridos em espaços públicos ou espaços privados de atendimento coletivo e visam manter o bom funcionamento das instituições, bem como evitar possíveis incertezas nesses ambientes. Ainda, encontramos pedidos impessoais que, apesar de poucos, aqui nos dados, se mostraram presentes como estratégia de pedido na sociedade brasileira.

A partir dessas considerações, esperamos que os aprendizes de português tenham a oportunidade de compreender, nas aulas de PL2E, alguns aspectos tratados sobre os atos de 
pedir neste trabalho para que possam aprender a identificar, no cotidiano brasileiro, a verdadeira pretensão dos diferentes solicitantes, nos diversos espaços em que circulam e agem como indivíduos autônomos. Mas desejamos, sobretudo, que estes alunos saibam-o que devem ou não transferir para o uso oral da língua. O fato de ver, por exemplo, expressões de baixo calão em avisos veiculados em placas e cartazes pode passar a impressão de que seu uso também é aceito naturalmente pela sociedade. Por isso, esses suportes podem auxiliar, nos contextos de aprendizagem, a situar e a pensar criticamente o uso das expressões polidas ou impolidas, da indiretividade, do uso do imperativo no português no Brasil e, principalmente, os não ditos que se escondem por trás dessas mensagens. Sabemos agora que é possível também conhecer um pouco do país através dessas inscrições.

Sugerimos, então, que pesquisas futuras sobre o tema aqui analisado possam abordar outras formas de construção de pedidos em variados contextos interacionais, levando em consideração os muitos aspectos culturais envolvidos na construção desses atos de fala.

Esperamos, portanto, que este trabalho possa fornecer ao professor de PL2E subsídios para a elaboração de estratégias eficazes de ensino e para a organização de suas aulas, uma vez que o reconhecimento e o conhecimento das estruturas linguísticas dos atos de pedir propicia também conhecimentos a respeito dos aspectos interpessoais de nossa dinâmica interacional. Assim, compreender como se desenvolve essa relação pode ser um caminho para se evitarem possíveis incompreensões. 


\section{Referências bibliográficas}

ALMEIDA, M. B. Sinalização e Identidade: Parque Zoológico do Rio Grande do Sul. Porto Alegre: Universidade do Rio Grande do Sul - Curso de Design, 2010.

ANDRADE, D. C. L. Contextualization cues in the notices on AVA: a contribution to the teaching of Portuguese Language in the modality distance. 2015. 167 f. Dissertação (Mestrado em Língua Portuguesa) - Pontifícia Universidade Católica de São Paulo, São Paulo, 2015.

AUleTE, F. J. C.; GEIGER, P. (Org.). Novíssimo Aulete dicionário contemporâneo da língua portuguesa. Rio de Janeiro: Lexikon, 2011.

AUSTIN, J. L. Quando Dizer é Fazer. Porto Alegre: Artes Médicas, 1990 [1962].

BATISTA, A. C. G. A linguagem dos mass media - uma análise sob o prisma da Pragmática. In: I Congresso Internacional de Estudos Filológicos e Lingüísticos, 2004, Rio de Janeiro. Círculo Fluminense de Estudos Filológicos e Lingüísticos, 2004.

BECHARA, E., 1928 - Moderna gramática portuguesa / Evanildo Bechara. - 37. ed. rev., ampl. E atual. conforme o novo Acordo Ortográfico. - Rio de Janeiro : Nova Fronteira, 2009.

BENNETT, M.J. (Ed.). Basic Concepts of Intercultural Communication: selected readings. Yarmouth, EUA: Intercultural Press, 1998.

BLUM-KULKA, S. Indirectness and politeness in requests: Same or different? Journal of Pragmatics, 11, p. 131-146, 1987.

BLUM-KULKA, S.; OLSHTAIN, E. Requests and apologies: A cross-cultural study of speech act realization Patterns (CCSARP). Applied Linguistics, 5 (3), p. 196-213, 1984.

BLUM-KULKA, S.; HOUSE, J.; KASPER, G.. Investigating cross-cultural pragmatics: An introductory overview. Cross-cultural pragmatics: Requests and apologies, v. 31, p. 1-34, 1989.

BRASIL. Presidência da República. Manual de Redação da Presidência da República / MENDES, G. F. \& JUNIOR, N. J. F. 2. ed. - Brasília: Presidência da República, p.1-129, 2002. Disponível em: <http://www4.planalto.gov.br/centrodeestudos/assuntos/manual-deredacao-da-presidencia-da-republica/manual-de-redacao.pdf > . Acesso em 20 nov. 2018.

BRISSAC, N. Ver o invisível: a ética das imagens. In: NOVAES, A. (Org.). Ética. São Paulo: Companhia das Letras, 1992. p.311.

BROWN, P.; LEVINSON, S. Politeness: Some universals in language usage. CambridgeUniversity Press, 1987 [1978]. 
COSTA, S. R. Dicionário de gêneros textuais. Autêntica: Belo Horizonte. 2009

CHAUÍ, M. Senso comum e transparência. O preconceito. São Paulo: Secretaria da Justiça e Defesa da Cidadania/Imprensa O'cial, 1996/1997.

CUNHA, C. F. da; CINTRA, L. F. L. Nova gramática do português contemporâneo. 5.ed. Rio de Janeiro: Lexikon, 2008.

DAMATTA, R. O que faz o Brasil, Brasil? RJ: Rocco, 1986.

A casa e a rua: espaço, cidadania mulher e morte no Brasil . $5^{\text {a }}$ ed. Rio de Janeiro, Rocco, 1997.

DAOLIO, J. Cultura: educação física e futebol. 3. ed. rev. Campinas, SP: Ed. da UNICAMP, 2006.

DIAS, L. S. Estratégia de Polidez Linguística na Formulação de pedidos e ordens contextualizados: um estudo constrativo entre o português curitibano e espanhol montevideano. Tese (doutorado em Linguística) - Programa de PósGraduação em Letras, Universidade Federal do Paraná, Curitiba, 2010. Disponível em: $<$ http://dspace.c3sl.ufpr.br/dspace/bitstream/handle/1884/

24943/TESE_EST.PDF>, acesso em 16.nov.2018.

DURANTI, A. Linguistic Anthropology. Cambridge: Cambridge University Press, 1997.

FERRARI, M.A. (Org.). Comunicação, interculturalidade e organizações: faces e dimensões da contemporaneidade. 1ed.Porto Alegre: ediPUCRS, 2015, v. , p. 249-278. Acesso: http://www.pucrs.br/edipucrs ISBN 978-85-397-0684-6 e-book - pdf

FLEURI, R. M. Desafios à educação Intercultural no Brasil. In: (Org.). Intercultura: Estudos emergentes. Ijuí: Unijuí, 2002. v. 1, p. 129-150.

GIBBS, G. Analise de dados qualitativos: Coleção Pesquisa Qualitativa. Bookman, 2009

GOFFMAN, E.. Interaction Ritual: essays on face-to-face behavior. New York: Doubleday Anchor. 1967. Books, 1971.

Relations in public: microstudies of public order. Middlesex, England, Penguin

.A Elaboração da face. In: FIGUEIRA, Sérgio Augusto. (org.) Psicanálise e ciências sociais. Rio de Janeiro: Francisco Alves, 1980.

GUERRA, A. R. Funções textual-interativas dos Marcadores Discursivos / Alessandra Regina Guerra. - São José do Rio Preto: [s.n.], 2007. 233 f. ; $30 \mathrm{~cm}$.

GRIPP, M. dos R. S.: p. 186. Semana de Letras (3. 2011: Curitiba, PR) Cadernos da Semana de Letras: trabalhos completos / Semana de Letras, 23 a 27 de maio de 2011, Curitiba, PR. Curitiba: UFPR: 2011. 481 p. 
GROHS, A.C.C.P. Comunicação intercultural: contribuições para a gestão internacional de organizações que atuam no contexto global. In: MOURA, C.P.; FERRARI, M.A.. (Orgs.). Comunicação, interculturalidade e organizações: faces e dimensões da contemporaneidade. Porto Alegre: ediPUCRS, 2015.

GUTIERRES, A. Relevância da pragmática e da teoria dos atos de fala para o ensino de inglês como língua estrangeira: tratamento dado a greetings em materiais didáticos. The Especialist, v. 9, n. especial, p. 187-209, 2008.

GUSSO, A. M.; SANTOS, K. P. ; SILVA, F. S. . Gêneros multimodais, letramentos múltiplos e escolarização. In: XI Congresso Nacional de Educação - EDUCERE, 2013, Curitiba. Formação docente e sustentabilidade: um olhar transdisciplinar, 2013.

KASPER, G. (ed.). CrossCultural Pragmatics: Requests and Apologies. Norwood, NJ: Ablex, p. 1-34, 1989b.

LARAIA, R. B. Cultura: um conceito antropológico. Rio de Janeiro: Jorge Zahar, 2001.

LE BERRE, C. C. Formulações dos atos diretivos, em língua oral, no Português do Brasil / Carla Chiappetta Le Berre ; orientadora: Rosa Marina de Brito Meyer ; co-orientador: Ricardo Borges Alencar. - 2007.

LEFFA, V. J. Metodologia do ensino de línguas. In BOHN, H. I.; VANDRESEN, P. Tópicos em lingüística aplicada: $O$ ensino de línguas estrangeiras. Florianópolis: Ed. da UFSC, 1988. p. 211-236.

LEIRIA, I. Português língua segunda e língua estrangeira: investigação e ensino. Idiomático, Lisboa: Centro Virtual do Instituto Camões, n. 3, p. 11, dez. 2004.

LIMA, R. Gramática normativa da língua portuguesa. Rio de Janeiro: José Olympio, 2010.

MARCUSCHI, Luiz Antônio. A questão do suporte dos gêneros textuais. Mimeo, 2003.

Produção textual, análise de gêneros e compreensão. São Paulo: Parábola Editorial, 2008.

MEJLACHOWICZ, S. A percepção do humor crítico brasileiro por alunos de português como segunda língua para estrangeiros (PL2E): o jogo de palavras em charges na mídia impressa e na internet. De volta ao futuro da lingua portuguesa. Atas do V SIMELP-Simpósio Mundial de Estudos de Língua Portuguesa, p. 3615-3628, 2017.

MEYER, R. M. B. Moço, me vê o cardápio: as formas de tratamento e o modo do subjuntivo no ensino do português carioca para estrangeiros. In: GÄRTNER, E. ET al. Estudos sobre o ensino da língua portuguesa. Frankfurt AM Main: TFM, pp. 141-151, 1999.

Questões interculturais entre o português do Brasil e o espanhol latinoamericano. In: SIMPÓSIO SOBRE ENSINO DE PORTUGUÊS, 2008, 1-15 (https://www.maxwell.vrac.puc-rio.br/12652/12652.PDFXXvmi=). 
. Para o bem ou para o mal: a construção de identidade pelo falante de PL2E a partir de estereótipos de brasilidade - uma questão cultural. In: MEYER, R. M. de B.; ALBUQUERQUE, A. (Org.) Português para Estrangeiros: questões interculturais. Rio de Janeiro: Ed. PUC-Rio, 2013. P. 13-34.

MENDES, E. O português como língua de mediação cultural: por uma formação intercultural de professores e alunos de PLE. In: MENDES, E. Diálogos Interculturais Ensino e formação em português língua estrangeira. Campinas, Pontes, p. 139-158, 2011.

A ideia de cultura e sua atualidade para o ensino-aprendizagem de LE/L2. EntreLínguas, Araraquara, v.1, n.2, p.203-221, jul./dez. 2015, p. $203-221$.

NEVES, M.H. de M. (2000) Gramática de Usos do Português. São Paulo: Pontes.

OLIVEIRA, F. S. Sorria! Você está sendo filmado? O olhar do estrangeiro sobre os brasileiros a partir das placas e cartazes informativos e de advertência. 2017. (Ensaios em Português como Segunda Língua ou Língua Estrangeira).

OLIVEIRA, L. M. de. Espaços públicos e privados das centralidades urbanas: Park Avenue, Avenida Paulista e Avenida Doutor Chucri Zaidan. 2013. 249 f. Tese (Doutorado em Arquitetura e Urbanismo) - Universidade Presbiteriana Mackenzie, São Paulo, 2013.

OLIVEIRA, M.C.L. (1995) Manda quem pode. Ou quem não tem juízo. Um estudo de diretivos no discurso empresarial brasileiro. In HEYE, J. (Org.) Flores Verbais. Rio de Janeiro: Nova Fronteira.

PINTO, E. P. O português popular escrito. São Paulo: Contexto, 1996.

HALL, Beyond Cultures. New York: Anchor Books, 1976. Livro digital (https://monoskop.org/images/6/60/Hall_Edward_T_Beyond_Culture.pdf)

The power of hidden differences. IN: BENNET, M. J. (ed.) Basic concepts or intercultural communication - selected readings. Yarmouth: Intercultural Press, 1998. P. 5367.

HOFSTEDE, G. (2001) Cultures \& consequences: Comparing values, behaviors, institutions and organizations across nations. 2nd ed. Thousand Oaks, London, New Delhi: Sage.

HOLANDA, S. B. de. Raízes do Brasil. São Paulo: Companhia das Letras, 1995.

RIBEIRO, B. T.; GARCEZ, P. M. Sociolinguística interacional. 2. ed. São Paulo: Loyola, 2002.

SPADOTTO, L. do N.; SANTORO, Elisabetta Antonietta Rita Maria Carmela. Ordens e pedidos em língua italiana: um estudo da percepção de falantes nativos e aprendizes brasileiros a partir da teoria dos atos de fala. 2016. Universidade de São Paulo, São Paulo, 2016. Disponível em: < http://www.teses.usp.br/teses/disponiveis/8/8148/tde-10052016$120022 />$. 
SANTOS, P. da S. Ordem ou pedido? Como os brasileiros interpretam atos de fala produzidos por aprendizes de PLE. Dissertação (Mestrado em Letras Vernáculas - Língua Portuguesa) - Universidade Federal do Rio de Janeiro, Faculdade de Letras.

SEARLE, J. R. Os actos de fala. Coimbra, Livraria Almedina, 1984.

Os atos de fala - um ensaio de Filosofia da Linguagem. Coimbra: Livraria Almedina. 1981.

Intencionalidade. São Paulo: Martins Fontes, 1995.

SPINASSÉ, K. P. Os conceitos de língua materna, segunda língua e língua estrangeira e os falantes de línguas alóctones minoritárias no sul do Brasil. In: Revista contingentia, V. 1, N. 1, Nov. 2006, p.01-10.

TAVARES, R. Conceitos de cultura no ensino/aprendizagem de línguas estrangeiras. In: TAVARES, Roseanne (org.) Língua, Cultura e ensino. Maceió: EDUFAL, 2006.

SILVA, V. B. C. da. Aspectos interacionais e culturais da ordem no ensino de português como segunda língua para estrangeiros (PL2E) em ambiente militar / Viviane Bousada Caetano da Silva ; orientadora: Rosa Marina de Brito Meyer. - 2015.

WATTS, R. J. Politeness. Cambridge: Cambridge University Press, 2003. 


\section{Anexos}

Figura 1: https://www.altasrisadas.com.br/blogs/insoonia/25-placas-que-mostram-o-quanto-obrasileiro-e-cordial

Figura 2: http://portaldoprofessor.mec.gov.br/fichaTecnicaAula.html?aula=34857

Figura 3: https://twitter.com/jose_simao/status/497395420159823872/photo/1

Figura 4: http://segueadica.com.br/placas-e-avisos-para-banheiro/

Figura 5: https://richardjakubaszko.blogspot.com/2013/12/placas-engracadas.html

Figura 6: http://www.criatives.com.br/2017/03/22-placas-engracadas-que-mostram-que-osbrasileiros-estao-totalmente-sem-paciencia/

Figura 7: https://img.buzzfeed.com/buzzfeed-static/static/2017-04/19/12/asset/buzzfeed-prodfastlane-03/sub-buzz-19096-1492619177-1.jpg?downsize=715:*\&output-

format=auto\&output-quality=auto

Figura 8: https://img.buzzfeed.com/buzzfeed-static/static/2017-04/19/12/asset/buzzfeed-prodfastlane-02/sub-buzz-25348-1492619264-1.jpg?downsize=715:*\&output-

format=auto\&output-quality=auto

Figura 9: http://www.brumadoagora.com.br/noticias/imprimir/17530-2015/12/14/recado-aosporcalhoes--foi-deixado-dentro-de-banheiro-da-prefeitura-de-livramento

Figura 10:

http://s2.glbimg.com/cN4Vgm3dhKeqr1MxladzfaD8A4=/620x465/s.glbimg.com/jo/g1/f/origi nal/2017/01/24/e_img_9293.jpg

Figura 11: https://www.buzzfeed.com/rafaelcapanema/100-imagens-sobre-o-dom-de comunicacao-do-brasileiro?utm_term=.vw0YwLdmz\&sub=4513741_10917302\#.grvRebdr9

Figura 12: http://barrancas.com.br/placas-faixas-engracadas/

Figura 13: https://pt.dop13r.com/memes/engra\%C3\%A7ado/pelo-amor-de-deus-naoestacioneao-suporto-mais-tanto-sofrimento/48522 -

Figura 14: https://www.ahnegao.com.br/2017/10/um-pedido-da-pessoa-que-limpa-o banheiro.html 
Figura 15: http://placas-digimetta.com.br/empresa-placas-sinalizacao/produto/placas-dehigiene-no-trabalho/povo-limpo-e-povo-civilizado.htm

Figura 16: http://paslu.com.br/wbp_produtos/placas-para-o-jardim/

Figura 17: Acervo Pessoal

Figura 18: https://www.buzzfeed.com/manuelabarem/14-anuncios-em-banheiros-que transformaram-o-momento-de-aliv?utm_term=.een46g5yV\#.akEgZBqPx

Figura 19: https://www.ahnegao.com.br/2017/10/um-pedido-da-pessoa-que-limpa-o banheiro.html

Figura 20: https://operacaofranca.com/2018/01/07/gleba-poetica/

Figura 21: http://mucarela.blogspot.com/2012/

Figura 22: http://www.aquariuslife.com.br/recolher-fezes-cachorro/

Figura 23: https://www.aquitemplacas.com.br/produtosDetalhes.php? $\mathrm{p}=$ aguarde-sua-vez-naofure-a-fila

Figura 24: https://www.aquitemplacas.com.br/produtosDetalhes.php? $\mathrm{p}=$ aguarde-sua-vez-naofure-a-fila

Figura 25: https://www.aquitemplacas.com.br/produtosDetalhes.php? $\mathrm{p}=$ mantenha-se-em-fila

Figura 26: Acervo pessoal

Figura 27:

http://sinatran.com.br/loja/index.php?route=product/product\&path=63_146\&product_id=454 9

Figura 28: http://www.mcgonroad.com.br/2011/11/

Figura 29: https://www.altasrisadas.com.br/blogs/insoonia/25-placas-que-mostram-o-quantoo-brasileiro-e-cordial

Figura 30:

https://www.balcaosobmedida.com.br/expositores-para-bijouterias/placas/plaquinha-naovendemos-fiado-ref-4520/

Figura 31: https://expanssiva.com.br/modelos/sinalizacao/jardins-e-gramados

Figura 32: https://images.app.goo.gl/KtnJc4MacmyJ8sFs6

Figura 33: https://charges.uol.com.br/emails-comentados/2007/01/02/nao-pise

Figura 34: https://www.elo7.com.br/kit-placas-rusticas-nao-pise-na-grama/dp/86AE25

Figura 35: http://www.mcgonroad.com.br/2011/11/ 
Figura 36: https://www.placassp.com.br/lembre-se-nao-jogue-fosforos-lixo-e-pontas-decigarro-no-vaso-sanitario

Figura 37: https://leopoldinense.com.br/noticia/5897/moradores-no-vale-do-sol-espalhamplacas-bem-humoradas-sobre-dejeto-de-caes

Figura 38: https://www.elo7.com.br/kit-placas-rusticas-nao-pise-na-grama/dp/86AE25

Figura 39: Acervo pessoal

Figura 40: https://leopoldinense.com.br/noticia/5897/moradores-no-vale-do-sol-espalhamplacas-bem-humoradas-sobre-dejeto-de-caes

Figura 41: https://sfocando.blogspot.com/2015/11/e-comum-voce-encontrar-exposto-nos.html

Figura 42: http://bitscaverna.com.br/cachorroblog/?p=2799

Figura 43: Acervo pessoal 